Министерство образования РФ

ФГБОУ ВО «Сочинский государственный университет»

Социально-педагогический факультет

Кафедра психологии и дефектологии

ФГБОУ ВО «Кубанский государственный университет», факультет управления и психологии,

кафедра психологии личности и общей психологии КубГУ,

Краснодарское отделение Российского психологического общества

\title{
Психология безопасности и психологическая безопасность: проблемы взаимодействия теоретиков и практиков в экспертно-психологических исследованиях
}

\author{
Сборник материалов \\ Всероссийского научного семинара \\ г. Сочи, 28-29 сентября 2018 г.
}

Под редакцией

3.И. Рябикиной, И.Н. Макаровой, Ю.Э. Макаревской

Сочи

ФГБОУ ВО «СГУ»

2018 


\title{
ББК 88.5
}

П86

\section{Редакционная коллегия:}

3.И. Рябикина, И.Н. Макарова, Ю.Э. Макаревская

\begin{abstract}
Психология безопасности и психологическая безопасность: п86 проблемы взаимодействия теоретиков и практиков в экспертнопсихологических исследованиях. Сборник материалов VIII Всероссийского научного семинара, г. Сочи, 28-29 сентября 2018 г. I Министерство образования РФ; Соч. гос. ун-т; Соц.-пед. ф-т СГУ; Под ред. З.И. Рябикиной, И.Н. Макаровой, Ю.Э. Макаревской. - Сочи: СГУ, 2018. - 120 с. - Электрон. текст. дан. (1 фрайл), ISBN - 978-5-6041266-84

Сборник материалов семинара раскрывает актуальные теоретические и практические проблем в области психологии безопасности.

Частная проблематика научного семинара определила рассмотрение и обсуждение таких проблем как взаимодействие теоретиков и практиков при производстве экспертно-психологических исследований, безопасность личности и её бытия в условиях современности.

Для студентов, аспирантов, преподавателей вузов, психологов, ученых.
\end{abstract}

ISBN - 978-5-6041266-8-4

УдК 316.628

ББК 88.5

DOI - 10.18411/sb-2018

IDSP - sbonline-2018

(С) ФГБОУ ВО «СГУ», 2018 


\section{Содержание}

ЧАСТЬ I. ПСИХОЛОГИЯ БЕЗОПАСНОСТИ И ПСИХОЛОГИЧЕСКАЯ БЕЗОПАСНОСТЬ: ПРОБЛЕМЫ ВЗАИМОДЕЙСТВИЯ ТЕОРЕТИКОВ И ПРАКТИКОВ В ЭКСПЕРТНО-ПСИХОЛОГИЧЕСКИХ ИССЛЕДОВАНИЯХ. СБОРНИК МАТЕРИАЛОВ ВСЕРОССИЙСКОГО НАУЧНОГО СЕМИНАРА Г. СОЧИ, 28-29 СЕНТЯБРЯ 2018 Г.

Андриенко Т.А., Лабунская В.А.

Особенности отношения молодых людей к наблюдаемому этнолукизму в связи с

самооценками внешнего облика

DOI - 10.18411/sb-2018-01

IDSP - sbonline-2018-01

Базалева Л.А., Базалев С.А.

Диагностика критического мышления у подростков: опыт исследования

DOI - 10.18411/sb-2018-02

IDSP - sbonline-2018-02

Гусейнов А.ШІ.

Искажение нравственных ценностей как ключевой фактор формирования экстремистских установок в молодежной среде

DOI - 10.18411/sb-2018-03

IDSP - sbonline-2018-03

Дубовиикая Т.Д., Серегин А.В.

Структурный анализ международных конфликтов (на примере Отечественный войны 1812 года)

DOI - 10.18411/sb-2018-04

IDSP - sbonline-2018-04

Ермолова В.О.

Смещение вектора ценностной ориентации подростков как одно условий нарушения психологической безопасности личности

DOI - 10.18411/sb-2018-05

IDSP - sbonline-2018-05

Зинатуллина А.П.

Взаимосвязь факторов профессионального выгорания и социальнопсихологического климата в подразделении федеральной службы войск национальной гвардии Российской Федерации

DOI - 10.18411/sb-2018-06

IDSP - sbonline-2018-06

Князькова М.Г., Пшеничный Д.К.

Проблема морально-психологической составляющей искусственного интеллекта в современных тенденциях замены юриста

DOI - 10.18411/sb-2018-07

IDSP - sbonline-2018-07

Курияов Н.А.

Психологические критерии безопасной образовательной среды ДОУ

DOI - 10.18411/sb-2018-08

IDSP - sbonline-2018-08

Макаревская И.Г.

Психологические предпосылки безопасности диагностического процесса в ситуации клиента и в ситуации экспертизы

DOI - 10.18411/sb-2018-09

IDSP - sbonline-2018-09 
Окорокова А.B.

Соотношение типов папиллярных узоров и типов $\mathrm{HC}$ : возможности

DOI - 10.18411/sb-2018-10

IDSP - sbonline-2018-10

Петросьян С.Н.

Девиантность как тип сценарного поведения личности: субъектно-бытийный подход

DOI - 10.18411/sb-2018-11

IDSP - sbonline-2018-11

Самохвалова А.Г.

Формы школьного насилия как фактор возникновения коммуникативных трудностей подростков, проживающих в зоне военных действий

DOI - 10.18411/sb-2018-12

IDSP - sbonline-2018-12

Cyxux C.A.

Опыт лингвопсихологического подхода в практике судебных экспертиз

DOI - 10.18411/sb-2018-13

IDSP - sbonline-2018-13

Теплякова А.П., Макаревская Ю.Э.

Проблема безопасности ребёнка в экспертно-психологических исследованиях интересов детей

DOI - 10.18411/sb-2018-14

IDSP - sbonline-2018-14

Тучина О.Р., Лялюк А.В.

Применение принципов субъектно-бытийного подхода при изучении рисков образовательной среды современного вуза

DOI - 10.18411/sb-2018-15

IDSP - sbonline-2018-15

Фролов А.А.

Безопасность в современном обществе: достояние каждого или привилегия избранных?

DOI - 10.18411/sb-2018-16

IDSP - sbonline-2018-16

Шеханина К.В.

Проблема консультирования родителей - участников высококонфликных разводов в постэкспертный период сопровождения

DOI - 10.18411/sb-2018-17

IDSP - sbonline-2018-17

Шиповская В.В.

Личностная беспомощность в аспекте проблемы виктимности субъекта 
Андриенко Т.А., Лабунская В.А., Шкурко Т.А.

Субъектно-личностные компоненты «многофакторной модели изучения отношения к внешнему облику»: переживание фрустрации ценности внешнего облика негативными оценками других

DOI - 10.18411/sb-2018-19

IDSP - sbonline-2018-19

Гиж ицкий B.B., Негрий В.A

Особенности психоэмоциональной и мотивационной сфер студентов, предрасположенных к научной деятельности

DOI - 10.18411/sb-2018-20

IDSP - sbonline-2018-20

Горская Г.Б., Егорова В.С.

Средовые факторы творческой самореализации личности: противоречия и ресурсы их преодоления

DOI - 10.18411/sb-2018-21

IDSP - sbonline-2018-21

Деева Н.А

Проблема жизненной успешности в изменяющейся социокультурной реальности

DOI - 10.18411/sb-2018-22

IDSP - sbonline-2018-22

Дёмин А.Н.

Психологическая готовность к преодолению кредитной задолженности

DOI - 10.18411/sb-2018-23

IDSP - sbonline-2018-23

Дёмин А.Н., Киреева О.В., Педанова Е.Ю.

Эмпирические предпосылки разработки опросника «Финансовый самоконтроль личности»

DOI - 10.18411/sb-2018-24

IDSP - sbonline-2018-24

Ермолова В.О.

Гендерная идентичность подростка в условиях виртуализации бытия

DOI - 10.18411/sb-2018-25

IDSP - sbonline-2018-25

Кара Ж.Ю.

Личность в эпоху виртуальной реальности

DOI - 10.18411/sb-2018-26

IDSP - sbonline-2018-26

Князева Г.Н., Князева Е.В., Чепелева Л.М.

Субъектный подход к самодвижению современной личности как субъекта образования

DOI - 10.18411/sb-2018-27

IDSP - sbonline-2018-27

Кругликова А.Ю.

Событийный подход в группах семейной логопсихотерапии для дошкольников 
Крутелева Л.Ю.

Взаимосвязь детско-родительских отношений и семейных сценариев у женщин среднего возраста

DOI - 10.18411/sb-2018-29

IDSP - sbonline-2018-29

Левченко Е.В., Меньшикова Л.В.

Православная вера как основа жизненного мира человека

DOI - 10.18411/sb-2018-30

IDSP - sbonline-2018-30

Макаревская Ю.Э., Рябикина З.И.

Факторный анализ признаков личностной идентичности

DOI - 10.18411/sb-2018-31

IDSP - sbonline-2018-31

Сериков Г.В

К вопросу о влиянии внешнего облика человека на его статус в группе

DOI - 10.18411/sb-2018-32

IDSP - sbonline-2018-32

Углава Я.М.

Психологическая устойчивость личности как базовая характеристика антикоррупционного поведения личности

DOI - 10.18411/sb-2018-33

IDSP - sbonline-2018-33

\section{Сведения об авторах}




\title{
ЧАСТЬ І. ПСИХОЛОГИЯ БЕЗОПАСНОСТИ И ПСИХОЛОГИЧЕСКАЯ БЕЗОПАСНОСТЬ: ПРОБЛЕМЫ ВЗАИМОДЕЙСТВИЯ ТЕОРЕТИКОВ И ПРАКТИКОВ В ЭКСПЕРТНО-ПСИХОЛОГИЧЕСКИХ ИССЛЕДОВАНИЯХ. СБОРНИК МАТЕРИАЛОВ ВСЕРОССИЙСКОГО НАУЧНОГО СЕМИНАРА Г. СОЧИ, 28-29 СЕНТЯБРЯ 2018 Г.
}

Андриенко Т.А., Лабунская В.А.

\author{
ОСОБЕННОСТИ ОТНОШЕНИЯ МОЛОДЫХ ЛЮДЕЙ К НАБЛЮДАЕМОМУ \\ ЭТНОЛУКИЗМУ В СВЯЗИ С САМООЦЕНКАМИ ВНЕШНЕГО ОБЛИКА* \\ *Исследование выполнено при поддержке Российского фонда фундаментальных \\ исследований (РФФИ), проект № 16-36-00049-ОГН\18
}

Введение. Решение многих проблем социальной психологии получает новые направления в связи с изменением среды социализации человека. Последние десятилетия изменили образ мира, расширили пространство бытия человека за счет формирования цифрового пространства. Вместе с этим, ряд вопросов социальной психологии, в частности, вопрос, касающийся факторов актуализации дискриминационного поведения, требует многостороннего изучения, именно, потому что открываются новые возможности дискриминационного отношения к различным группам. Если ранее исследователи $[2,10,12,13,11]$ отмечали, что в современном обществе многие дискриминационные практики (сексизм, эйджизм и т.д.) становятся скрываемыми, маскируемыми, то в настоящее время некоторая бесконтрольность цифрового пространства позволяет выражать дискриминационное отношение к Другому более откровенно, выбирать способы обращения, комментарии, которые не косвенно, а прямо указывают на дискриминационное поведение. Учитывая тот факт, что цифровое пространство переполнено «визуальными текстами», фото и видио информацией, усиливается стремление людей отреагировать на внешний облик человека и группы лиц. Все чаще, в основе категоризации людей лежит какой-либо признак внешнего облика. Цифровое пространство возвращает к феномену «клички», но, если такая «школьная практика» имела границы, то цифровое пространство снимает любые ограничения. Язык интернета становится проводником «Языка вражды» [1,17], обыденные обозначения этно - культурных групп на основе типа внешнего облика преобразуются в цифровом пространстве в способы демонстрации дискриминационного отношения к Другому. В этой связи, по-новому звучит проблема наблюдаемого или воспринимаемого дискриминационного поведения [5], поскольку, именно, в цифровом пространстве в режиме «реального времени» появляются оценки, комментарии, свидетельствующие о том, принимает или не принимает субъект воспринимаемое дискриминационное поведение. В соответствии с проблемой, описанной выше, появляется необходимость изучения различных социально-психологических, субъектно -личностных факторов, влияющих на принятиенепринятие воспринимаемого дискриминационного поведения.

В данной статье рассматривается влияние такого субъектно-личностного фактора, как самооценка субъекта восприятия дискриминационного поведения Другого. Самооценка изучается, как самооценка внешнего облика, а в качестве дискриминационной практики рассматривается этнолукизм.

Методология исследования. В наших публикациях [4,6,7] мы отмечали, что этнолукизм - это «обыденная» дискриминационная практика, направленная на представителей этнокультурных групп с определенным типом внешнего облика. О взаимосвязи лукизма и этнической дискриминации свидетельствуют распространенные не только в политической, но и в повседневной коммуникации обозначения этнокультурных групп с помощью таких словосочетаний, как «лица кавказской национальности», «лица славянской внешности» [17], перекочевавшие в пространство интернета. «Кокетливый, шутливый расизм», за которым стоит «новая волна расизма» [14], иными словами, этнолукизма - это один из способов 
маскировки этнолукизма в цифровом пространстве. Слова и словосочетания «азиаты», «укропы», «кавказцы» или «лица славянской внешности» не имеют прямого отношения к антропологическим особенностям внешнего облика, порой, эти слова не фиксируют конкретную этническую группу, но актуализируют сложившиеся стереотипы, предрассудки, которые начинают управлять не только поведением, но и восприятием, в целом, отношением.

В основе заявляемого в наших публикациях [4,5] подхода лежит структурно-системный анализ отношения к этнолукизму и на передний план выходит изучение когнитивноэмоциональных образований, в частности, оценочного компонента отношения и самооценки, как единицы самоотношения. Несмотря на наличие большого количества работ, включающих изучение дискриминационного поведения, например, в качестве факторов рассматриваются предрассудки, предубеждения, сложившиеся стереотипы $[10,15,16]$, до настоящего времени остается недостаточно исследованным вопрос о влиянии субъектноличностных факторов, не только на дискриминационное поведение человека, но и на его отношение к воспринимаемой дискриминации.

Таким образом, в данной статье мы рассматриваем восприятие и отношение к этнолукизму как дискриминационному поведению Другого, направленному на представителей этнокультурных групп, отличающихся типом внешнего облика. В качестве эмпирического фактора изучаем роль самооценки внешнего облика, как компонента самоотношения, в принятии/непринятии воспринимаемого этнолукизма. В эмпирической части исследования проверялась гипотеза: принятие/непринятие воспринимаемого дискриминационного поведения Другого, направленного на представителей этнокультурных групп, отличающихся типом внешнего облика, может быть обусловлено самооценками компонентов и характеристик внешнего облика.

\section{Методы исследования}

1.С целью определения уровня принятия дискриминационного поведения, направленного на представителей этно-культурных групп, отличающихся типом внешнего облика (в нашей терминологии «принятия этнолукизма»), использовалась ситуативная методика «Диагностика уровня принятия дискриминационного поведения Другого, направленного на представителей этно-культурных групп в различных ситуациях взаимодействия» [3,7]. Она включает 15 ситуаций, в которых одним из действующих лиц выступает либо мужчина, либо женщина, отличающиеся типом внешнего облика, а другим - человек, осуществляющий по отношению к первому дискриминационные действия. Ситуации взаимодействия были следующие: «Оказание услуги», «Совместное проживание», «Прогулка по городу», в контексте которых изменялся гендер дискриминируемого лица, его этно-культурная принадлежность, обозначенная посредством принятых в современном языке определений типа внешнего облика («славянский внешний облик», «кавказский внешний облик» и «азиатский внешний облик»). В процессе выполнения задания респондентам необходимо было выбрать меру согласия (по пятибалльной системе) с дискриминационными действиями, направленными на человека с определенным гендерным статусом и этнокультурным типом внешнего облика.

2.Опросник «Оценочно-содержательная интерпретация своего внешнего облика», разработанный В.А. Лабунской $[8,9]$. Он включает следующие шкалы: эстетические оценки лица; тела; оформления внешнего облика; интегральные характеристики внешнего облика шкалы: оценки привлекательности своего внешнего облика для противоположного пола; феминности - маскулинности внешнего облика. Респондентам предлагается оценить на основе десяти бальной системы степень соответствия эстетических параметров различных компонентов внешнего облика своему внешнему облику. самооценка внешнего облика рассчитывается на основе суммирования баллов по каждому виду самооценок и деления суммы баллов на число видов самооценок.

3. Математические процедуры: однофакторный дисперсионный анализ, Т - критерий парных выборок, критерий Манна-Уитни - U. 
В исследовании приняли участие 66 молодых людей в возрасте от 25 до 35 лет, 36\% мужчин и $64 \%$ женщин.

\section{Результаты и выводы:}

1.Важным результатом нашего исследования является то, что участники исследования не принимают дискриминационное поведение Другого, проявление этнолукизма. Средние показатели: «интегральный показатель уровня принятия дискриминационного поведения Другого в различных ситуациях взаимодействия»; «уровень принятия дискриминационного поведения Другого в конкретных ситуациях взаимодействия («оказание услуги», «совместное проживание», «прогулка по городу»); «уровни принятия наблюдаемого дискриминационного поведения, направленного на людей с различным типом внешнего облика («славянский тип внешнего облика, «кавказский тип внешнего облика», «азиатский тип внешнего облика»; «уровни принятия наблюдаемого дискриминационного поведения, направленного на мужчин или женщин не зависимо от ситуации и типа внешнего облика» находятся в диапазоне от 1,29 до 1, 58 баллов. В соответствие с пятибальной оценкой согласия с наблюдаемым дискриминационным поведением, такие средние показатели являются низкими и свидетельствуют о том, что большинство участников исследования не принимают наблюдаемую дискриминацию. Вместе с этим, исходя из минимальных и максимальных оценок согласия с дискриминационным поведением, можно констатировать, что внутри группы участников исследования имеются те, у которых высокий уровень согласия с дискриминационным поведением.

2.Критерий T - парных выборок указывает на то, что молодые люди - участники исследования имеют более высокие оценки согласия с дискриминационным поведением, если в ситуациях взаимодействия дискриминируются лица с «кавказским типом внешнего облика» по сравнения с оценками согласия с дискриминацией людей со «славянским типом внешнего облика» $(\mathrm{T}=-3,556 ; \mathrm{p}=0,001)$ и «азиатским типом внешнего облика» $(\mathrm{T}=3,218$; $\mathrm{p}=0,002)$. Участники исследования имеют более высокие оценки согласия с дискриминацией женщин, чем мужчин $(\mathrm{T}=1,76 ; \mathrm{p}==0,083$.).

3.Показатель U указывает на отсутствие влияния гендерного фактора на оценки согласия с наблюдаемым дискриминационным поведением. Можно отметить только тот факт, что у женщин «интегральный показатель принятия наблюдаемого дискриминационного поведения» выше, чем у мужчин ( $\mathrm{U}=-1,403 ; \mathrm{p}=0,161)$.

4.Однофакторный дисперсионный анализ фиксирует влияние интегральной самооценки внешнего облика на интегральный уровень принятия наблюдаемого дискриминационного поведения ( $\mathrm{F}=2,046 ; \mathrm{p}=0,037)$. Эти данные говорят о том, что уровень самооценки внешнего облика может объяснять индивидуальные различия в принятии - согласии с наблюдаемым дискриминационным поведением.

Заключение. Современные молодые люди не принимают наблюдаемое дискриминационное поведение, направленное на представителей этнокультурных групп, отличающихся типом внешнего, несмотря на то, что существенным аспектом их социализации является цифровое пространство. Влияние сложившихся стереотипов и предрассудков, которые сформировались до «цифровой эпохи», но не изменились в результате воздействия коммуникации, осуществляемой в цифровом пространстве, проявляется в том, что повышается уровень принятия наблюдаемого дискриминационного поведения, направленного на представителей этнокультурных групп с «кавказским типом внешнего облика», разворачивающего в ситуации «совместного проживания», направленного на женщин. Субъектно - личностный фактор - самооценка внешнего облика оказывает влияние на принятие-непринятие воспринимаемого дискриминационного поведения. Уровень самооценки внешнего облика объясняет индивидуальные различия в принятии - согласии с наблюдаемым дискриминационным поведением. 


\section{Литература}

1.Альперович В.Д. Образы «своих» и «чужих» людей, врага и друга в метафорах и представлениях личности// Успехи современной науки и образования, 2016. Том 4. №7. С. 96-102.

2.Бзезян А.А. Лукизм и этническая дискриминация//Северо-Кавказский психологический вестник, 2012. №10/3. С.21-23.

3.Бзезян А.А. Социально-психологические особенности отношения к дискриминации представителей этнических групп с различным типом внешнего облика. Автореферат диссертации кандидата наук. Ростов-на-Дону, 2015. 23c.

4.Лабунская В.А. Методология исследования взаимосвязей отношений, образов, форм обращений в контексте межэтнического общения //ОТ ИСТОКОВ К СОВРЕМЕННОСТИ: 130 лет организации психологического общества при Московском университете: Сборник материалов юбилейной конференции. М.: Когито-Центр, 2015.Т.3. С.264-267.

5.Лабунская В.А. От психологии внешнего облика А.А. Бодалева к построению эмпирических моделей изучения отношения к этнолукизму в обыденном общении// Лицо человека в пространстве общения. М.: Московский институт психоанализа - Когито - Центр, 2016. C.73-97.

6.Лабунская В.А., Бзезян А.А. Особенности «Арpearance» стереотипов этно-культурных групп с различными типами внешнего облика//Международный научно-исследовательский журнал успехи современной науки и образования, 2016. №9, Т. 2. С.77-84.

7.Лабунская В.А., Бзезян А.А. Особенности дискриминационного отношения к представителям этнокультурных групп: гендерно-ситуационный анализ / Гендерные реалии 21 века: сборник научных статей. Ростов-на-Дону: Изд-во ЮФУ, 2014. С. 130-134.

8.Лабунская В.А., Капитанова Е.В. Самооценка и оценка внешнего облика членов студенческой группы как предикторы отношений межличностной значимости // Социальная психология и общество, 2016. Т. 7. № 1. С. 72-87.

9.Лабунская В. А. Не язык тела, а язык души! Психология невербального выражения личности. Ростов на Дону: Феникс, 2009. 344 с.

10.Майерс Д. Социальная психология. СПб.: Прайм-Еврознак, 2002. 512c.

11.Opex Е.А. Феномен лукизма и возможности его социологического анализа / Социологический журнал, 2016. № 3. С.67-81.

12.Погонцева Д.В. Виды дискриминации по внешнему облику// Психология и психотехника, 2013. № 9. С. 858-861.

13.Погонцева Д.В. Формы проявления этнолукизма (на примере современных зарубежных исследований)/Личность и бытие: человек как субъект социокультурной реальности: материалы Всероссийская научно- практическая конференция. Краснодар: Кубанский государственный. Университет, 2016. С.112-114.

14.Расизм, ксенофобия, дискриминация. Какими мы их увидели/ Сб. статей; сост. и отв. ред. Екатерина Деминцева. М.: Новое литературное обозрение, 2013. 384 с.

15.Татарко А.Н., Лебедева Н.М. Психология межэтнических отношений. Этническая идентичность и стратегии межкультурного взаимодействия. М.: Изд-во «Институт психологии РАН», 2010. 190с.

16.Шефер Б., Скарабис М., Шледер Б. Социально-психологическая модель восприятия чужого: идентичность, знание, амбивалентность // Психология, 2004.№1. С.24-51.

17.Ярская В.Н. Язык мой - враг мой: расистский дискурс в российском обществе// Социологические исследования. 2012, № 6. С. 46-53. 
Базалева Л.А., Базалев С.А.

\section{ДИАГНОСТИКА КРИТИЧЕСКОГО МЫШЛЕНИЯ У ПОДРОСТКОВ: ОПЫТ ИССЛЕДОВАНИЯ}

Сегодня общество требует подготовленных квалифицированных специалистов, а одной из задач современной школы является подготовка молодых людей к дальнейшему усвоению знаний в высших учебных заведениях.

Школьники должны научиться сравнивать, анализировать, обобщать, абстрагировать, конкретизировать. Все это не только способствует более прочному усвоению знаний, но и поможет им в будущем решать трудные, нестандартные задачи, работать творчески и находить выход из любой ситуации.

Андрей Шаронов, президент Московской школы управления «Сколково» утверждает, что «сегодня человек за жизнь в среднем меняет 8 видов деятельности». Команда профессионалов под его руководством, выявила компетенции, которые позволяют быть успешным независимо от специфики деятельности и направления, в котором работает человек. Это критическое мышление, креативность, умение разрешать конфликты, умение управлять мультинациональной командой.

В настоящее время достоинством школьного обучения является возможность за короткое время передать большой объем информации. При таком обучении школьники усваивают знания в готовом виде. Кроме того, оно предполагает усвоение и воспроизведение знаний, и их применение в аналогичных ситуациях. Среди существенных недостатков этого типа обучения можно назвать его ориентированность в большей степени на память, а не на мышление. Это обучение также мало способствует развитию творческих способностей, анализу, самостоятельности, активности. Наиболее типичными заданиями являются следующие: вставь, выдели, подчеркни, запомни, воспроизведи, реши по примеру и тому подобное.

Средствами развития критического мышления, кроме специальных техник, используемых педагогами, на наш взгляд также могут выступать стратегические компьютерные и настольные игры. Это увлечение приобретает всю большую популярность у современных школьников.

Эти виды игр направлены на достижении победы. В них необходимо постоянно перестраивать план на прохождение, менять тактику и взаимодействовать с множеством персонажей, а также управлять огромным количеством ресурсов. Для того, чтобы достичь нужных результатов, нужно научится формулировать проблему, составлять четкий план действий, обдумывать тактику, принимать важные решения. Все эти действия в игре позволяют быть более рассудительным, высказывать свою точку зрения, брать ответственность не только за себя, но и других. Такие стратегические действия возможно ведут к развитию критического мышления.

В данной статье представлены результаты диагностики критического мышления подростков, увлекающиеся различными видами игр: как настольными так и компьютерными.

Настольные и компьютерные - онлайн игры имеют ряд сходств: взаимодействие в реальном времени, общение между игроками, создание некого воображаемого мира отличного от реального, нахождение выхода из сложившиеся ситуации, поиск самостоятельного решения. В этих играх мы можем отыграть роли различных персонажей, временно перевоплощаясь в вымышленных героев, проживать их жизнь.

В качестве диагностического инструментария была использована методика «Тест оценки критического мышления подростков» Ю.Ф. Гущина.

В исследовании приняли участие 72 школьника, учащихся 9 классов. 
В первую группу вошли школьники увлекающихся компьютерными онлайн- играми. Эти дети играют в компьютерные игры очень часто - ежедневно от 1 до 4 часов в день. Всего 16 человек - 22,2\% от всей выборки.

Во вторую группу вошли школьники, увлекающиеся настольными играми. Они играют очень часто-1-2 раза в неделю от 2 до 5 часов. Всего 16 человек $-22,2 \%$ от всей выборки.

В третью группу, вошли школьники, не играющие или играющие, время от времени (2 раза в неделю и реже) в компьютерные онлайн-игры и не играющие или играющие время от времени (очень редко не чаще 1 раза в месяц) в настольные игры такие как: шашки, шахматы, домино, нарды, карты, монополия, Уно и др. Всего 40 школьников - 55,6\% от всей выборки.

У большинства школьников 49 человек (68\%) был выявлен средний уровень критического мышления. Эти учащиеся умеют не поддаваться внушающему влиянию чужих мыслей, а строго и правильно оценивают их, рассматривают проблемы с разных точек зрения, устанавливают множественные связи между явлениями, выстраивают прогнозы и обосновывают их. Пусть не всегда, но таким детям удается видеть сильные и слабые стороны высказываний и мнений и те ошибки, которые допущены в них.

У 16 школьников (22,2\%) уровень развития критического мышления характеризуется либо отсутствием, либо очень слабым развитием качеств критического мышления. Такие школьники не имеют тщательно взвешивать все доводы за и против своих гипотез и не подвергают их всесторонней проверке. Они как правило не самокритичны, несамостоятельны в своих решениях.

У 7 школьников $(9,7 \%)$ диагностируется высокий уровень. Они обладают гибкостью, самостоятельностью и критичностью ума; рассматривают проблемы с различных точек зрения, хорошо анализируют поставленные проблемы, предлагают конкретные решения.

Во всех группах средний уровень развития критического мышления, преобладающий. Но в первой (увлекающихся онлайн играми) и третьей группах (не увлекающимися играми) присутствует низкий уровень развития критического мышления. И во второй группе (увлекающимися настольными играми) отсутствует низкий уровень, а также $38 \%$ школьников этой группы обладают высоким уровнем критического мышления.

При этом подростки увлекающиеся компьютерными играми лучше, чем не играющие, справлялась с заданиями на умение анализировать и делать заключение о причинах явлений, нахождением ошибок в тексте, нахождением информации на фоне избыточной и обнаружение ошибок связанных с неопределенностью терминов. Старшеклассники, не играющие, лучше, чем игроки в онлайн-игры справились заданиями, направленными на умение оценивать последовательности умозаключений и умение анализировать и делать заключение о причинах явлений.

Проанализируем, являются ли эти различия статистически значимыми. Для этого осуществим статистический анализ полученных данных. Обработка осуществлялась в универсальном статистическом пакете SPSS-v20.0. В качестве критерия для статистической обработки был выбран непараметрический статистический критерий U-Манна-Уитни.

Мы сравнили между собой группы поочередно между собой.

В группах, увлекающихся онлайн-играми, и не увлекающихся игрой значимых различий не обнаружено. В группах, увлекающихся настольными играми, и не увлекающихся игрой существуют статистически значимые различия (при $\mathrm{p}=0,01$ ). В группах, увлекающихся онлайн-играми и настольными играми существуют статистически значимые различия (при $\mathrm{p}=0,000)$.

Таким образом, наша гипотеза частично подтвердилась. Школьники, играющие в настольные игры, обладают повышенным уровнем критического мышления, по сравнению с другими группами.

Старшеклассники, играющие в компьютерные онлайн-игры, показали более низкие результаты, нежели другие группы. Возможно это связанно с чрезмерными затратами потраченного времени на компьютерные игры. Для настольщиков частота игра составляет 1- 
2 раза в неделю, а для подростков, играющих в онлайн игры, несколько часов в день. Соответственно в первом случае остается меньше время на саморазвитие.

Также в настольных играх ты обсуждаешь партию с собеседниками, имеешь возможность открыто поговорить с другими игроками и всегда вовлечен в речевой поток, независимо от желания. В компьютерных играх ты можешь принимать или не принимать участие в онлайнразговоре по своему желанию.

Кроме того за настольной партией ты проводишь игру со своими знакомыми. В дружеской обстановке максимально раскрываются способности человека. В компьютерных онлайн играх ты не видишь собеседника, не имеешь представления о том, кто он такой, чем он занимается и иногда обнаруживаешь, что виртуальный собеседник настроен враждебно по отношению к тебе. Этот довод подтверждает утверждение Шакировой Д.М., критическое мышление - это мышление индивидуальное и самостоятельное, но проявляется оно в спорах, дискуссиях, при обсуждениях и публичных выступлениях, поэтому коммуникативные навыки участников осмысления проблемы для формирования данного типа мышления играют решающую роль в успехе.

Таким образом, игровая деятельность является одним из условий развития мыслительных способностей человека. Традиционно в отечественной психологической науке игровая деятельность прочно ассоциирована с дошкольным возрастом, однако сам психологический феномен игры наблюдается у людей разных возрастов.

Несмотря на кажущуюся общность настольных и компьютерных онлайн-игр. Школьники, играющие в настольные игры, обладают повышенным уровнем критического мышления. Возможно, это связано со следующими причинами:

- выработка собственной игровой стратегии для достижения желаемого результата;

- возможность не только самостоятельно выбирать решения, но и обсуждать их с другими игроками;

- высокая речевая активность;

- доброжелательная обстановка во время проведения игры.

Школьники, играющие в настольные игры, обладают повышенным уровнем критического мышления, по сравнению с другими группами. Игровая активность способна оказывать влияние на качество и темп развития высших психических функций в целом и мыслительных процессов в частности.

\section{Литература}

1. Бустром, Р. Развитие творческого и критического мышления / Р. Бустром - М.: Открытое общество, 2000. - 215с.

2. Загашев, И.О., Заир-Бек, С.И. Критическое мышление: технология развития / И.О. Загашев, С.И. Заир-Бек. - СПб.: Альянс-Дельта, 2003. - 284 с.

3. Клустер Дэвид. Что такое критическое мышление. Электронный ресурс. Режим доступа// http://rus.1september.ru/article.php?ID=200202902

4. Ковалева, Л.В. Технология развития критического мышления / Л.В.Ковалева. - ГорноАлтайск: ИПКРОРА, 2005. - 189 с.

5. Скурыгина С. К. Взгляды зарубежных ученых на сущность критического мышления // Молодой ученый. - 2016. - №7. - С. 708-710. Режим доступа// https://moluch.ru/archive/111/27218/

6. Х Халперн, Д. Психология критического мышления / Д. Халперн. - СПб.: Питер, 2000.$224 \mathrm{c}$.

7. Шаронов Андрей. Лекция о концепции life-long learning, paботе с собой и внешним миром, личной эффективности. Электронный ресурс// http://hr-elearning.ru/lekciya-prezidentaskolkovo-life-long-vuca-effectivnost/ 


\section{ИСКАЖЕНИЕ НРАВСТВЕННЫХ ЦЕННОСТЕЙ КАК КЛЮЧЕВОЙ ФАКТОР ФОРМИРОВАНИЯ ЭКСТРЕМИСТСКИХ УСТАНОВОК В МОЛОДЕЖНОЙ СРЕДЕ}

Современный этап развития социогуманитарного познания характеризуется пристальным вниманием к внутреннему миру субъекта, к экзистенциально-онтологическим аспектам человеческого бытия $[8 ; 9 ; 11 ; 16]$. Сущность личностного бытия, его сложность и противоречивость невозможно описать без обращения к ценностям, главной из которых является сам человек с присущей ему потребностью в реализации собственного масштаба в мире. Понятие «ценности» фокусирует внимание на изменениях экзистенциальной сущности субъекта, приобретении совершенно новых субъектных качеств в результате их усвоения и трансляции. Соответственно, с помощью этого понятия раскрываются психологические механизмы духовного преобразования человека или негативной трансформации личности в результате нарушения ценностно-смысловой регуляции [4; 14].

Предложено немало объяснений социогенезиса и природы общечеловеческих и личностных ценностей. Ценности существуют в неразрывном единстве трех форм их существования, постоянно переходящих друг в друга: 1) в форме общественных идеалов, представляющих концентрированное выражение коллективного опыта группы или общности; 2) в форме предметного воплощения этих общественных идеалов в произведениях (артефактах) и поступках конкретных людей; 3) в форме мотивационных компонентов личности, побуждающие к предметному воплощению ценностных идеалов в поведении и поступках [11, с. 23]. Переход ценности из одной формы в другую является способом бытия ценностей.

Личностные ценности как ядерные компоненты структуры личности всегда выполняют функцию устойчивых источников побуждений и в конкретных повседневных ситуациих порождают во взаимодействии и конкуренции с другими подобными источниками мотивы текущей активности. Несмотря на функциональную идентичность личностных ценностей и потребностей, между ними имеются существенные различия, обусловленные тем, что человек как субъект потребностей взаимодействует с миром в одиночку, а как субъект ценностей - как часть целого. В процессе личностного становления и социализации к разнообразным и противоречивым потребностям как изначально единственным источникам побуждений прибавляются ценности. При этом между этими структурными компонентами психики устанавливается баланс, который иногда может нарушаться [11]. Соответственно соотношение потребностей и личностных ценностей в регуляции жизнедеятельности является существенной индивидуальной характеристикой личности, проявляет специфику субъектной активности.

Общепризнано то, что именно общество задает развивающейся личности общие принципы восприятия и интерпретации мира, определяет значение тех или иных аспектов жизни, формирует направленность на определенные ценности, гарантирующие предсказуемый и нужный социуму эффект. Предъявляя систему общественных норм и образцов, общество указывает, какие эмоции и поступки, в каких ситуациях ценятся или не одобряются социумом [1]. С. Московичи считает, что индивид не столько мыслит сам, сколько актуализирует в себе опыт прошлых поколений, цитирует их социальный опыт мышления [13, с. 98].

Процесс открытия ценностей и усвоения индивидом программ социального наследования, кристаллизованного опыта поколений осуществляется через специальные социальные институты, выполняющие функции образования и воспитания.

Если на ранних стадиях личностного становления семья является единственным центром, влияющим на усвоение социальных ценностей, то в подростковом возрасте ситуация меняется и альтернативным каналом усвоения ценностей становится референтная группа. Если подросток испытывает потребность в принадлежности к девиантной группе, и она 
становится для него референтной, ценности более широких объединений, в том числе универсальные общечеловеческие ценности он воспринимает сквозь призму ценностей этой деструктивной группы, которая воспроизводит антигуманные и антиобщественные ценности $[11 ; 12]$.

Общество, стремясь к самосохранению и стабильности социальных структур, заинтересовано в создании условий для целенаправленного управления личностными ценностями. При этом также следует учитывать возможное несовпадение личностных и общественных ценностей.

Но если социальность сводится лишь к форме принуждения, диктату, с помощью которых общество насильственно навязывает индивиду определенную систему норм и духовных ценностей, то формируется не двусторонняя, а лишь однонаправленная связь индивида с обществом, которое авторитарно воздействует на него, превращая его лишь в объект внешних влияний. В результате человек как субъект лишается нормальных условий жизни и может стать изгоем по отношению к данному конкретному обществу, типу культуры. Поэтому А.В.Брушлинский не согласен был с тем, что усвоение исторического опыта является главным и единственным механизмом психического развития человека, подчеркивал важность активной жизненной позиции, которая дает возможность избирательно относится к различным социальным воздействиям, не позволяет быть пассивным потребителем информации и пропаганды [2; 3]. Соответственно, социальное становится личностным в том случае, если приобретает ценность, значимость для индивида, удовлетворяя его многообразные потребности, в том числе духовные.

В связи с циркуляцией ценностных содержаний между общественным сознанием, культурными артефактами и деяниями и индивидуальной мотивацией ценностно-смысловые позиции личности, выражающие ценностное отношение субъекта к миру, могут подвергаться глубинной трансформации, с последующей реализацией радикальных идей в экстремистской деятельности. В этом случае наблюдается феномен эрозии, девальвации, фальсификации и искажения ценностей.

Именно в переходные, транзитивные периоды процесс усвоения индивидом ценностей выходит из-под контроля социокультурных и образовательных институтов и попадает в первую очередь под власть субкультурных и деструктивных влияний, опасных в плане психологического воздействия [6]. В исследованиях показано, что российское общество, пережившее «перестройку», а затем ввергнутое в радикальные и нередко непродуманные реформы, постоянно испытывало моральные девиации, дефицит нравственных ориентиров, ценностей и образцов поведения [18]. Заметной тенденцией в общественной жизни становится постепенная утрата российским обществом своей яркой национальной специфики и обретение характеристик западных обществ, нацеленных преимущественно на рыночные, материальные, приземленные ценности.

Психологи едины во мнении, что на этапе глобализации наше государство оказалось не готово к определению путей и средств формирования ценностей молодежи - социальной группы, чувствительной к происходящим процессам, обладающей небольшим жизненным опытом и поэтому уязвимой к деструктивным влияниям. Кроме того, институты морального контроля в современном российском обществе до сих пор практически отсутствуют. Вслед за моралью из сознания молодежи и других слоев нашего общества испаряются такие категории, как «отзывчивость», «бескорыстие», «патриотизм», «доброта». Сакральная функция российского педагога, аккумулирующего, анализирующего и передающего опыт поколений молодежи, призванного транслировать и формировать духовные ценности, утрачена и заменена на должность служащего, по сути, слуги, производящего «образовательные услуги».

Следствием глубоких девиаций в социальных структурах, криминализации бытовой культуры и отсутствия ценностно-нормативного единства становится ценностно-смысловая дезориентация личности, беспомощность [15; 17], усиливающая эффект дискредитации и 
подмены гуманистических ценностей (свободы, независимости) искаженными ценностями референтной группы.

Некритичное усвоение и ассимиляция безнравственных групповых норм создают благодатную основу для личностной деструктивности, которая находит выход во вхождения подростков и молодежи в субкультурные объединения, интернет-сообщества, которые становятся для них референтными группами, источником социальной и личностной идентичности. В подобных сообществах молодые люди, которым свойственна экстремальность сознания, создают лжегероев и получают возможность реализовать деструктивные формы протеста - нигилизм, оппозицию, негативизм, эскапизм [5; 7; 8]. В результате негативных ценностных трансформаций искажается понимание свободы, ответственности и солидарности: свобода совести подменяется вседозволенностью, приказ деструктивного лидера заменяет совесть и личную ответственность, солидарность, сотрудничество и взаимовыручка подменяются узкоклановыми интересами. Желание выделиться из среды любой ценой, следование собственным примитивным потребностям самовозвышения становится центральным императивом экстремистской личности.

Понимание ценностей предполагает раскрытие специфики субъектной активности личности, поскольку ценностно-смысловое самоопределение и субъектная активность личности являются взаимообусловленными процессами. В нашем исследовании выявлено, что во всех деструктивных формах протестной активности наблюдается заостренность ценностно-целевых приоритетов вокруг полюса D-смыслов (деструктивность и фиксация на теме смерти), наличие низкоуровневых примитивных защит, порождающих искаженную и упрощенную интерпретацию картины мира, когда собственная враждебность приписывается другим людям и обществу. Наблюдается нарушение иерархии в ценностно-смысловой системе, дискредитация и подмена гуманистических ценностей искаженными ценностями. Подчеркнем самое главное - субъект не видит себя в неразрывной связи с миром и другими людьми и не способен практиковать индивидуальный стиль морально-нравственного поведения.

Следовательно, неудовлетворительное разрешение проблемы ценностно-смыслового самоопределения в системе разноуровневых противоречий приводит к духовному кризису, формирует экстремистские установки и становится фундаментом для социальнодеструктивных явлений в молодежной среде. Назрела необходимость задуматься о возрождении нравственности в российском обществе, прежде всего, усилить роль педагога как носителя гуманистических ценностей в социуме.

\section{Литература}

1. Анцыферова Л.И. Психология формирования и развития личности // Человек в системе наук / ред. Т.И. Фролов. М.: Наука, 1989. С. 426-433.

2. Брушлинский А.В. Проблемы психологии субъекта. М.: Институт психологии РАН, 1994.

3. Брушлинский А.В. Субъект безопасности и безопасность субъекта // Проблемы информационно-психологической безопасности. Сборник статей и материалов конференции. - М.: Изд-во Ин-та психологии РАН, 1996. - С. 39-43.

4. Гусейнов А.Ш. Психологические предпосылки зарождения и поддержания экстремистского мировоззрения молодежи // Казанский педагогический журнал. 2016. № 3 (116). С. 120-127.

5. Гусейнов А.Ш. Искажение субъектности в некоторых видах протестной активности // «Личность и бытие: субъектный подход» (к 80-летию А.В. Брушлинского): Матер. VI Всерос. науч.-практ. конф. (с ин. уч.) под ред. З.И. Рябикиной, В.В. Знакова. М., Краснодар: КубГУ, 2013. С. 273-275.

6. Гусейнов А.Ш., Шиповская В.В. Протестная активность личности в эпоху глобализации // Межкультурная коммуникация и проблемы толерантности (междисциплинарный подход): материалы Международной научной конференции, 6-7 
октября 2017 г., г. Ереван / под ред. д-ра экон. н. проф. А.С. Молчана - Краснодар: ФГБОУ ВО «КубГТУ», 2017. - 342 с. С. 37-42.

7. Гусейнов А.Ш., Фоменко Г.Ю., Рябикина З.И. Протестная активность личности в контексте субъектно-бытийного подхода // Человек. Сообщество. Управление. 2015. (16) №3. C. 6-21.

8. Гусейнов А.Ш., Рябикина 3.И., Фоменко Г.Ю., Шиповская В.В. Феномен протестной активности личности: субъектно-бытийная интерпретация // Российский психологический журнал. Том 14, № 4, 2017. С. 78-96.

9. Знаков В.В., Рябикина 3.И. Психология человеческого бытия. М.: Смысл, 2017.

10. Левашов В.К. Социополитическая динамика российского общества: 2000-2006. М.: Академия, 2007.

11. Леонтьев Д.А. От социальных ценностей к личностным: социогенез и феноменология ценностной регуляции деятельности // Вестник Московского ун-та. Сер 14. Психология. 1996. №4. С. 35-44.

12. Леонтьев Д.А. Ценностные представления в индивидуальном и групповом сознании: виды, детерминанты и изменения во времени // Психологическое обозрение. 1998. №1. С.1325.

13. Московичи С. Век толп. Исторический трактат по психологии масс / пер. с франц. М.: «Центр психологии и психотерапии», 1996.

14. Шиповская В.В., Гусейнов А.Ш. Ценностно-смысловые аспекты личностного становления: субъектно-бытийная интерпретация // Акмеология, 2014. (1-2). С. 245-246.

15. Шиповская В.В. Деструктивные аспекты проявления личностной беспомощности: междисциплинарный подход / Психология опасности и безопасности. В 2-х книгах. Книга вторая: Психологические модели субъектности и безопасности социального субъекта (Ч.3, Ч.4) / Под ред. С.Н. Тесля, И.Б. Шуванова. Сочи, РИЦ СГУ, 2012. С. 253-267.

16. Шиповская В.В. Отчуждение и экзистенциальная беспомощность подростков как показатели неаутентичности личностного бытия // Личность и бытие: человек как субъект социокультурной реальности: материалы Всероссийской научно-практической конференции / под ред. 3.И. Рябикиной и В.В. Знакова. Краснодар: Кубанский гос. ун-т, 2016. С. 270-273.

17. Шиповская В.В. Беспомощность как фактор формирования экстремистских установок в подростковой среде // Казанский педагогический журнал, 2017. № 5 (124). С. 125-131.

18. Юревич А.В., Ушаков Д.В. Нравственность в современной России // Психологические исследования. 2009. № 1(3). URL: http://psystudy.ru (дата обращения: 12. 09. 18).

Дубовиикая Т.Д, Серегин А.В.

\section{СТРУКТУРНЫЙ АНАЛИЗ МЕЖДУНАРОДНЫХ КОНФЛИКТОВ (на примере Отечественный войны 1812 года)}

Конфликтология как наука, начав свое поступательное развитие в русле философии и социологии, в последние десятилетия приобретает психологическую ориентацию, поскольку все большее значение в возникновении и протекании конфликтов начинает придаваться субъективным факторам. Данное обстоятельство с одной стороны позволяет открыть новые перспективы в исследовании социальных конфликтов, а с другой - предъявляет особые требования к разработке психологической теории конфликта. Это, в частности, касается понимания психологической сущности и структуры конфликта. Некоторые аспекты данной проблемы отражены в наших предыдущих работах [3],[4]. В данной статье представлено авторское понимание сущности и структуры конфликтов на примере анализа конкретного международного конфликта.

Внимание к международным конфликтам обусловлено их значительными негативными последствиями для десятков, сотен, миллионов людей. Профилактика данных конфликтов 
особенно актуальна в современном глобальном мире и требует рассмотрения и анализа всех их аспектов. В нашей работе мы исходим из понимания конфликта и его структуры как социально-психологического явления, отличающегося от философско-социологической традиции, согласно которой конфликт определяется через понятия «столкновение» и «противоречие», не отражающие в полной мере его психологической сущности.

Как разновидность межгруппового конфликта, международный конфликт в нашем понимании - это деструктивное взаимодействие групповых субъектов (в лице народов/армий разных стран во главе с их лидерами), возникающее вследствие восприятия действий друг друга, как представляющих угрозу для реализации своих стремлений $u$ достижения поставленных иелей.

Международные конфликты традиционно рассматриваются историческими науками, в русле которых анализ конфликтов предполагает, как правило, выявление и содержательное наполнение следующих аспектов: стороны (участники) конфликта, причины (предпосылки и поводы), ход (этапы) конфликта, итоги/исход.

В психологии и конфликтологии разработаны несколько иные модели структуры конфликта. В частности, Л.А. Петровская [6] в структуре конфликта выделяет следующие элементы: стороны (участники) конфликта (личности и социальные группы); условия протекания конфликта (социально-групповая и социально-психологическая среда); образы конфликтных ситуаций - идеальные картины конфликтных ситуаций, а не сама реальность, которые определяют выбор стратегии поведения участников. Они влияют на содержание их представлений, оценок и суждений.

Согласно Н.В. Гришиной [2], структуру конфликта составляют: стороны (участники) конфликта; условия конфликта; предмет конфликта; действия участников конфликта; исход (результат) конфликта.

Исследователи конфликтов А.Я Анцупов, А.И. Шипилов[1] различают в структуре конфликта объективную (материальную) и субъективную (идеальную или психологическую) подсистему. Объективную систему представляют: стороны (участники) конфликта, объект конфликта, предмет конфликта, микро- и макросреда конфликта. Субъективная система включает в себя: мотивы сторон, конфликтное поведение (принципы, стратегии, тактики), информационные модели (восприятие оппонентами конфликта). Субъективная подструктура конфликта рассматривается исследователями как решающая в его возникновении, развитии и завершении.

В целях создания комплексной картины исследуемого конфликта нами предлагается следующая расширенная соичильно-психологическая структурно-динамическая модель конфликта, включающая три группы составляющих: объективные (поддающиеся объективному анализу), субъективные (психологические особенности, свойственные личности участников и групповым субъектам конфликта), функционально-динамические (характеризуют процесс, особенности протекания конфликта и его последствия). Представим их содержательные элементы.

К объективным составляющим конфликта относятся:

1) стороны (участники) конфликта;

2) объект конфликта; предмет конфликта;

3) действия участников конфликта;

4) макро- и микросреда, в которых протекает конфликт;

5) вид конфликта.

К субъективным составляюшим конфликта относятся:

1) образы конфликтной ситуации в сознании ее участников, включая видение оппонента, самого себя, вероятных результатов борьбы;

2) мотивы действий сторон;

3) цели, которые они преследуют;

4) актуальные психические состояния участников (включая переживаемые чувства, страхи и опасения). 
К функционально-динамическим составляющиим конфликта относятся:

1) стадии протекания конфликта;

2) стратегии поведения конфликтующих;

3) функции конфликта (конструктивные и деструктивные результаты/итоги конфликта).

Отличительной особенностью социально-психологического анализа конфликта в отличие анализа конфликтов в исторической науке является внимание к субъективной стороне конфликта, рассмотрение которой необходимо для профилактики конфликтов, а также для всестороннего объективного изучения, позволяющего влиять на их динамку. Отметим, что содержательное наполнение названных компонентов может быть разным по глубине, мы остановимся на основополагающих составляющих.

Представим применение данной структуры к анализу реального международного конфликта. В качестве объекта анализа выступила «Отечественная война 1812 года» или, как ее называют французы, «Русская кампания Наполеона» [5],[7]. Итак, 12 июня 1812 войска Наполеона переправились через реку Неман, положив тем самым начало войне между двумя империями - французской и российской. Продолжалась данная война до 14 декабря 1812 года и завершилась полной и безоговорочной победой русских и союзнических с ней войск.

Объективные составляющие конфликта

Стороны (участники) конфликта.

Прямые стороны: Франция (в лице Наполеона и его армии) и Россия (в лице Александра I, М.И. Кутузова, армии и русского народа).

Косвенные страны-участники: союзник России - Великобритания; союзники Франции побежденные и подчиненные Наполеону страны - итальянские и германские княжества, Австро-Венгрия и др.

Особенности макросредь, оказавшие влияние на ход конфликта.

Франция являлась страной победившей революции. К июлю 1807 года французская армия Наполеона успешно покорила Европу, захватив Италию, часть Австрии, присоединила к себе Бельгию, Голландию, взяла под свое покровительство германские княжества, захватила Пруссию, пообещала свободу Польше и объявила блокаду Англии. Французы несли на своих штыках идею свободы от феодализма.

Экспедиционный корпус русской армии, пытаясь помочь своим европейским союзникам, одержал над французскими войсками ряд тактических побед. Но, в составе объединенной армии союзников Россия потерпела стратегическое поражение на европейском театре военных действий и была вынуждена подписать договор с Наполеоном, который предполагал со стороны России континентальную блокаду Англии (Тильзитский мир, июль 1807 г.).

Особенности микросредьл.

Неоднозначное отношение к Наполеону в самой Франции. В то же время армия Наполеона считалась лучшей в Европе. Ее возглавляли талантливые полководцы и гениальный главнокомандующий. В ее состав, помимо французов, входили также австрийцы, голландцы, итальянцы, прусаки, поляки, швейцарцы, испанцы, вдохновленные ее победами. Россия и старый противник - Британская Империя, остались для Наполеона единственными державами на пути к мечте о мировом господстве. В Тильзите Наполеон попытался Россию сделать своим помощником в противоборстве с Англией.

Россия к 1812 году являлась государством с крепостническим сельским хозяйством. Верхушка аристократии была настроена против «выскочки» Наполеона и не на шутку опасалась революционной заразы. В то же время царь, воспитанный бабушкой Екатериной II на трудах французских просветителей, и значительная часть русской интеллигенции симпатизировали если не методам, то целям великих преобразований. В европейских боях армия показала, что русские могут побеждать французов, но и сила противника тоже была знакома не понаслышке.

Действия участников конфликта, предшествовавшие возникновению войны.

Со стороны России: 
- фактический срыв договоренностей в Тильзите о блокаде Англии согласно Тильзитскому соглашению, что подрывало планы Франции по завоеванию Англии;

- отказ Наполеону в династическом браке (в 1808 году с княжной Екатериной, в 1810 году с княжной Анной) и как следствие невозможность для Наполеона реализовать его стремление стать «помазанником божьим», а также наследственным монархом (которым он не являлся) и получить русского императора в союзники, как родственника;

- переброска Россией войск к границе с Польшей в 1811 году (из-за опасений восстания Польши, которое могло перейти на Россию), оцененное Наполеоном, как подготовка России к войне за польские территории, подчинявшиеся на том момент Франции.

Со стороны Франции:

- обещания Наполеона польской элите воссоздать Речь Посполитую, что предполагало включение в нее западных земель России;

- отказ Наполеона очистить Пруссию от французских войск вопреки Тильзитскому соглашению, чем Александр I был очень недоволен.

Объект конфликта (как объект разногласия сторон): мировое могущество государств. Особенно данное обстоятельство было актуально для Франции. Хотя и Россия в Тильзите выдвигала условия распространения своей власти на Финляндию, Балканы и даже Константинополь.

Предмет конфликта (как противоречие/проблема, из-за которого стороны оказались в противоборстве): отказ России от поддержки Франции в ее стремлении к мировому могуществу.

Вид конфликта. По сфере проявления - политический, по степени длительности - острый, длительный; по субъектам конфликтного взаимодействия - межгрупповой, международный.

Субъективные составляюшие конфликта

Образы конфликтной ситуации в сознании ее участников.

Действия России по отношению к Франции, вернее даже сказать молчаливый саботаж, нежелание России действовать с Наполеоном заодно, могли восприниматься Наполеоном как угроза его стремления к мировому могуществу и даже как обман, граничащий с изменой. В 1811 году Наполеон заявил своему послу в Варшаве аббату де Прадту: «Через пять лет я буду владыкой всего мира. Остаётся одна Россия, - я раздавлю её...».

У России также были реальные опасения возможного нападения со стороны армии Наполеона, но сама нападать на Францию она не собиралась. В данной войне действия России носили оборонительный и освободительный характер.

Мотивы действий сторон. Наполеон стремился к мировому господству. Россия стремилась сохранить свою независимость, для нее это была освободительная борьба с захватчиком.

Цели сторон. Для обеих сторон целью была - победа над противником. Наполеон ждал, что захват Москвы принудит русских просить мира. В свою очередь, Александр I собирал силы для того, чтобы дать достойный отпор армии Наполеона и освободить от него Россию.

Психическое состояния участников конфликта.

Россияне: чувство патриотизма, разочарование в идеалах французской революции, неоднозначное отношение к руководству российской армией на начальном этапе отступления и всенародная поддержка в период наступления и преследования.

Французы: самоуверенность Наполеона, безоговорочная вера солдат армии Наполеона в своего лидера и свою победу на этапе наступления, бесстыдное мародерство и разграбление Москвы во время ее оккупации, страх и сожаление во время позорного шествия из Москвы.

Функиионально-динамические составляющие конфликта

Динамика конфликта - стадии (этапы) развития конфликта и их содержание.

1) Предконфликтная стадия. Триумфальное шествие армии Бонопарта по Европе за пять лет до войны с Россией. Вынужденное подписание Россией Тильзитского мирного договора. Молчаливое нарушение его условий и подготовка к неизбежному открытому противостоянию. 
2) Собственно конфликт.

Первый этап (июнь - сентябрь 1812 г.) - отступление русских армий от границ России до Смоленска. Героическая оборона смоленского гарнизона. Бородинское сражение перед Москвой.

Второй этап (октябрь - декабрь 1812 г.) - сорванное Кутузовым намерение наполеоновской армии уйти на зимние квартиры, отступление до границ России по разоренным ею же дорогам, преследование русской армией, гибель солдат многих солдат от голода и мороза.

Третий этап (1813 г.) - перенос военных действий на земли европейских стран и самой Франции. После того, как наспех собранная новая французская армия также потерпела поражение (в «Битве народов» под Лейпцигом 16-19 октября 1813 г.), казачья и башкирская конница в марте 1814 года взяли Париж.

3) Постконфликтная стадия. Наполеон отрекся от престола. Попытка его вновь вернуться к власти в 1815 также окончилась неудачей. Рост международного престижа России.

Стратегии (стили) поведения конфликтующих: соперничество и противостояние, отказ России от уступок и компромиссов.

Функиии международного конфликта (роль конфликта для жизни народов - его участников).

Значение войны 1812 года для Франции.

- Франция избавилась от Наполеона и его планов на мировое господство.

С другой стороны:

- гибель значительного числа солдат армии Наполеона (потери составили около 580 тысяч солдат из 610 тысяч на начало наступления)

- возвращение династии Бурбонов и части старых порядков, не отвечавших интересам французского народа

Деструктивное значение войны 1812 года для России:

- возникновение длительного отчуждения между Россией и Францией (отношения улучшились лишь к концу 19-го века);

- разрушение городов и сельского хозяйства, исчезновение в огне московского пожара многих драгоценных реликвий прошлого.

Позитивное значение войны 1812 года для России:

- признание мировым сообществом ведущей роли России в разрушении планов Наполеона о мировом господстве, значительный рост престижа России на мировой арене;

- рост патриотических чувств среди населения;

- рост национального самосознания и образования и начало освободительной борьбы за отмену крепостного права, за провозглашение конституции (декабристы называли себя «детьми 1812 года», треть которых принимала участие в войне 1812 года);

- толчок к развитию русской культуры (создание по мотивам войны 1812 года многочисленных стихов, песен, романов, статей, картин художников);

- возвышение Москвы как духовного центра России.

Для всего мира:

- создание новой системы международных отношений.

Следует отметить отсутствие четких критериев различий конструктивных и деструктивных последствий конфликтов: что для одной стороны конструктивно, для другой может оказаться деструктивным, более того, одно и то же последствие оценивается поразному представителями различных социальных групп в одной стране, в зависимости от их групповых или даже личных интересов.

Используя предложенную структурно-динамическую модель конфликта можно проанализировать практически любой международный конфликт и выйти на поиск путей управления ими, включая профилактику, прогнозирование, диагностику, разрешение/урегулирование. Данное обстоятельство принципиально для изучения конфликтов в рамках учебных курсов истории в образовательных целях. Структурные 
элементы данной модели могут предлагаться обучающимся для собственного наполнения их содержанием, используя для этого различные источники. К тому же, опора на данную модель позволит выявить «белые пятна» в изучении войны. Особенно это касается субъективных составляющих конфликта и его негативных последствий для жизнедеятельности людей. Изучение войны в процессе обучения не может ограничиться формальным усвоением определенных знаний - фактов и дат. Необходимо создавать условия для понимания не только объективных, но и субъективных предпосылок войны, для формирования негативного отношения к войне, как форме деструктивного взаимодействия, и поиска направлений конструктивного решения возникших разногласий.

\section{Литература:}

1. Анцупов А.Я., Шипилов А.И. Словарь конфликтолога. - СПб.: Питер, 2006. - 528 с.

2. Гришина Н.В. Психология конфликта. - СПб.: Питер, 2002. - 464 с.

3. Дубовицкая Т.Д. Межэтнические и межгосударственные конфликты в контексте психологии межгрупповых отношений // Социальный мир человека: Материалы VII Международной научно-практической конференции "Человек и мир: миросозидание, конфликт и медиация". Сер. "Язык социального" Под редакцией Н.И. Леонова. 2018. - С. 279-283.

4. Дубовицкая Т.Д. Микро- и макроструктура межличностного конфликта: практикоориентированный подход // Психология обучения. 2017. № 1. С. 110-116.

5. История Франции (отв. ред. А.3. Манфред). В трех томах. Том 2. - М.: Наука, 1973. $664 \mathrm{c}$.

6. Петровская Л.А. Теоретические и методологические проблемы социальной психологии. - M., 1977. C. 126-143.

7. Тарле Е.В. Наполеон. - Москва, Берлин: Директ-Медиа, 2008. - 760 с.

Ермолова В.О.

\section{СМЕЩЕНИЕ ВЕКТОРА ЦЕННОСТНОЙ ОРИЕНТАЦИИ ПОДРОСТКОВ КАК ОДНО УСЛОВИЙ НАРУШЕНИЯ ПСИХОЛОГИЧЕСКОЙ БЕЗОПАСНОСТИ ЛИЧНОСТИ}

В современной психологии ценностные ориентации рассматриваются как стержень сознания, являются важнейшим элементом внутренней структуры личности, концентрирующий жизненный опыт индивида и представляющий систему переживаний. Изучая ценностные ориентации личности в подростковом возрасте, мы отмечаем, что структура ценностей современной молодежи отличается выраженной ориентацией на достижения и личный успех. Значимость благосклонности (забота о благополучии других людей и общества) существенно снижается, а наименее предпочитаемыми оказываются ценности традиций.

Ценностные ориентации выражают сознательное отношение человека к социальной действительности, определяют мотивацию его поведения и оказывают существенное влияние на все стороны его жизнедеятельности. Подростковый возраст является наиболее благоприятным периодом для образования ценностных ориентаций как устойчивого свойства личности.

Ценности подростков сегодня образуют два вектора. Во-первых, вектор духовности, характеризующийся господством нравственных установок, гуманизма, человеколюбия. Вовторых, ценности, нацеленные на индивидуализм, приоритет материального над духовным, отличающиеся утилитаризмом и практицизмом.

Исследования, проведенные В.Е. Семеновым [3], показали, что главными жизненными ценностями подростков являются семья, друзья и здоровье, затем следуют: интересная 
работа, деньги и справедливость (значение последней ценности в настоящее время возрастает). Замыкает семерку главных жизненных ценностей религиозная вера.

Одной из самых главных ценностей людей является свобода [1, с. 165-170].Без сомнения, свобода слова, действий, выбора необходимы для самоутверждения и самосовершенствования, однако свобода без ответственности становится вседозволенностью и ведет к социальному хаосу. Свобода самовыражения и общество потребления - две стороны одной медали. Идеология потребительства, консьюмеризма получает широкое распространение среди молодого поколения, чему способствует фактическое отсутствие всякой цензуры в СМИ, широкое распространение рекламы. Поэтому ценность свободы в ее классическом понимании значительно расходится с пониманием данной ценности подростками.

Следующая жизненная ценность - осознание необходимости здоровья. Здоровый человек сможет чувствовать себя полноценной личностью, ощущать всю красоту и прелесть жизни во всех ее проявлениях.

Сегодня заметна тенденция восстановления таких ценностей, как «спокойная жизнь», «душевная гармония», значимость равенства возможностей, интересной работы. Возвращение данных ценностей в число «центровых», основных свидетельствует о том, что общество получает некую стабильность, и социальная структура приобретает черты таковой устоявшегося общества. Для современной молодежи более важными сегодня являются: деньги, образование и профессия, деловая карьера и удовольствия; она больше ориентирована на индивидуальные ценности [3, с. 40].Однако, существуют такие аспекты политической жизни, на которые молодые люди не могут не обратить внимание. Это, прежде всего, пассивность граждан. Отсюда - растущие надежды на «сильного лидера». Также необходимо отметить, что подростков стали сильнее волновать проблемы качества и уровня образования, кризиса семьи, спада рождаемости.

Еще одна ценность - патриотизм [2, с. 143-147].Любовь к родной земле, уважение к государству, чувство долга перед родиной должны присутствовать в сознании современной молодежи.

Тем не менее, не все ценности положительны. Негативным в ценностной сфере подростков является тот факт, что отсутствует четкая связь между работой и деньгами, так как одни получают большие деньги путем авантюр и манипуляций, а другие много работают, но имеют неадекватно маленькую заработную плату. Подростки это прекрасно понимают, поэтому запросы молодых и их требования при поступлении на работу значительно изменились.

По данным современных исследований существует значительная переоценка ценностей: предпочтение отдается материальным потребностям (деньги, вещи), деловым связям, индивидуальным интересам (как стать здоровым, богатым, знаменитым и т. п.).

В целом изменения в ценностных ориентациях подростков обусловлены заметными изменениями политической, экономической, социально-психологической ситуации в обществе.

В нынешней ситуации социализации подростка, когда происходит глобальная трансформация общественного строя, очень важно оберегать юное поколение от состояния социальной фрустрации и всячески содействовать его прогрессивному росту.

Иначе подростки сконцентрируют в себе те социально-психологические характеристики «маргиналов», которые будут создавать трудности в ходе их интеграции в социальные институты и социальные отношения. Постепенно обостряясь и углубляясь, становясь все более устойчивыми, такие социально-психологические новообразования имеют негативный оттенок, деформируют подростка, приводят к грубости и жестокости в отношениях, к наркомании, проституции, преступлений.

Есть также опасность, что, легко потеряв ориентиры и став удобным объектом разного рода (политического, преступного и т.д.) манипулирования, подростки могут свернуть на 
путь антисоциального поведения, впасть в агрессивность или социальную апатию, а их активность может приобрести направленность деструктивного характера.

Наиболее значимыми различиями процесса социализации современного юного поколения являются:

- переоценка ценностных ориентаций и смена идеалов;

- расширение референтных связей и изменение содержательности общения в них;

- снижение уровня саморегуляции.

Сравнительный анализ ценностных ориентаций подростков 70-90-х годов XX века позволяет сделать вывод, что у современного поколения, которое подрастает, ценности общественного характера уступили ценностям индивидуального характера.

Среди современных подростков значительно обесценились качества общественной направленности при одновременном повышении значимости качеств индивидуальной направленности. Изучение ценностных ориентаций благополучных и трудновоспитуемых подростков свидетельствует, что первые в основном ориентируются на ценности, которые имеют моральную направленность, другие - выбирают ценности с материальной направленностью.

Среди современных трудновоспитуемых, в отличие от их предшественников, имеет место усиление девальвации моральных ценностей и ценностей, связанных с трудовой деятельностью. Нынешние подростки характеризуются высоким уровнем личностной тревожности. Среди них возросла обеспокоенность проблемами, связанными с будущей жизнью, профессиональным самоопределением, взаимопониманием с родителями, экологической ситуацией в стране.

Параллельно с этим уменьшилась важность проблем в сферах самосовершенствования и жизни людей, которые их окружают. Современные подростки не осознают зависимости будущих жизненных достижений от качества полученного образования. Произошли изменения в иерархии желаемых профессий: среди них престижными считаются профессии менеджера, юриста, врача, экономиста, а уж потом - учителя.

Непосредственные причины того или иного поведения подростка неразрывно связаны с целым рядом противоречий общества, социальной среды, микросреды и самой личности.

Среди главных условий, которые провоцируют внутренние и внешние противоречия, выделяют следующие:

- недоступность для современного подростка тех условий образования, воспитания, профессионализации, развития, которые необходимы для нормальной социально-культурной адаптации личности в данном обществе;

- бедность прямых и косвенных связей и отношений подростка с другими людьми;

- несоответствие упрощенных способов поведения и деятельности, которые навязываются подростковым окружением, восхищенных экзистенциальным стремлением возраста;

- большая дистанция между духовной сосредоточенностью, идеальными ожиданиями от жизни и реальными результатами, и эффектами поступков и действий подростка;

- сужение границ свободного передвижения в пространстве, строгий регламент времени для творческого самовыражения, увлечений, игр;

- неспособность подростком фиксации «Я в жизни», отрешенность от самопознания, рефлексии;

- преимущество деструктивных сил, которые постоянно выходят из личности данного подростка, над заложенными в нем силами развития, конструктивного жизни;

- несоответствие уровня выявленных способностей и ранее закрепленных качеств подростка задачам, которые он ставит перед собой;

- неприятие (отчуждение окружения, что является значимым для подростка) результатов его самовыражения;

- преувеличение ближайшим окружением подростка уровня его взрослости, возможностей и продуктивности деятельности, сформированности его способностей; 
- опережая масштабность жизненных задач и стратегий подростка по сравнению с постепенностью и зацикленностью его жизненного и социального созревания;

- реальная угроза духовному и физическому существованию подростка, которая выходит из агрессивной социальной и природной среды.

Формирование ценностных ориентаций у подростков является для различных исследователей предметом пристального внимания и разнопланового изучения. Исследование подобных вопросов особое значение приобретает в подростковом возрасте, поскольку именно с этим периодом онтогенеза связан тот уровень развития ценностных ориентаций, который обеспечивает их функционирование как особой системы, оказывающей определяющее воздействие на направленность личности, ее активную социальную позицию.

\section{Литература}

1. Бадретдинова Г.3. О молодежной духовной культуре: проблема поворота к человеку как «ценности» // Гуманитарные, социально-экономические и общественные науки. 2014. № 9 .

2. Варданян Ю.В., Руськина Е.Н. Субъектная и компетентностная обусловленность развития психологической безопасности в системе образования //Интеграция образования. - 2017. - № 1. - С. 79-82.

3. Идзиковски Б. Формирование ценностных ориентаций, влияющих на жизненную и профессиональную карьеру молодежи в Польше. М., 2007. - 349 с.

4. Кабаченко Т.С. Методы психологического воздействия. М.: Педагогическое общество России, 2010. - 539 с.

5. Карелин А. Большая энциклопедия психологических тестов. М.: Эксмо, 2017. 416 c.

6. Климов Е.А. Развивающийся человек в мире профессий. Обнинск: Принтер, 2013. - $57 \mathrm{c}$.

7. Котик М.А. Психология и безопасность / М.А. Котик. СПб.: Питер, 2016. - 207c.

8. Методика «Диагностика реальной структуры ценностных ориентаций личности» (С.С. Бубнова) 2015г.

9. Платонов К.К. Структура и развитие личности. - М., 2016. - 254 с.

10. Райгородский Д.Я. Подросток и семья. - М.: Бахрах-М, 2013. - 656 с.

11. Руськина Е.Н. Формирование психологической защиты школьников от манипулирования: основные положения // Вестник Пятигорского государственного лингвистического университета. - 2009. - № 1. - С.316-321.

12. Шадриков В.Д. Педагогическая поддержка профессионального самоопределения старшеклассников. - М.: ВЕКС, 2008. - 165с.

Зинатуллина А.П.

\section{ВЗАИМОСВЯЗЬ ФАКТОРОВ ПРОФЕССИОНАЛЬНОГО ВЫГОРАНИЯ И СОЦИАЛЬНО-ПСИХОЛОГИЧЕСКОГО КЛИМАТА В ПОДРАЗДЕЛЕНИИ ФЕДЕРАЛЬНОЙ СЛУЖБЫ ВОЙСК НАЦИОНАЛЬНОЙ ГВАРДИИ РОСССИЙСКОЙ ФЕДЕРАЦИИ.}

Известно, что любая профессиональная деятельность, связанная, в первую очередь, с постоянным взаимодействием с людьми, высоким уровнем ответственности, риска, эмоциональной вовлеченностью, может стать причиной такого синдрома как «профессиональное выгорание». Это особенно актуально для сотрудников полиции Войск национальной гвардии Российской Федерации. Профессиональный род деятельности военнослужащих, полицейских протекает в стрессовых условиях борьбы с преступностью, нарушением правопорядка, применением оружия. Высокая работоспособность, боеготовность в экстремальных ситуациях достигается посредством значительного нервноэмоционального напряжения, которое приводит к развитию профессиональной патологии, 
эмоциональному выгоранию сотрудников. Взаимодействие в служебном коллективе, состояние социально-психологического климата также оказывает влияние на полицейских. Часто сотрудники отмечают у себя чувство безразличия, апатии, нежелания продолжать военную службу, негативизм по отношению к коллегам и руководству, неудовлетворенность собой. Не всегда сотрудники готовы обратиться с этой проблемой к психологу, а профессиональное выгорание может спровоцировать негативные последствия служебной деятельности полицейских.

В связи с этим, важно говорить о необходимости профилактики эмоционального выгорания сотрудников. Одним из направлений является своевременная психодиагностика, выявление военнослужащих, полицейских с симптомами эмоционального выгорания, а также мониторинг состояния морально-психологического климата в служебных коллективах.

Впервые термин «выгорание» предложен американским психиатром Х.Дж.Фрейденбергом в 1974 году. Изучением синдрома эмоционального выгорания занимались такие отечественные исследователи как: Т.В.Форманюк, В.В.Бойко, О.О.Руковишников, В.Е.Орел, Е.С.Старченкова и другие. Для диагностики профессионального выгорания сотрудников психологами Росгвардии используются методики: «Диагностика эмоционального выгорания» В.В.Бойко, Опросник «Профессиональное (эмоциональное) выгорание (МВI) адаптация Водопьянова Н.Е. (автор К. Маслач и С.Джексон). Данные методики позволяют измерить степень «выгорания» в профессиях типа «человек-человек».

В первом квартале 2017 года проведено исследование состояния профессионального (эмоционального) выгорания сотрудников подразделения Войск национальной гвардии Российской Федерации». Изучение проводилось с применением методики К. Маслач, С.Джексон «Диагностика профессионального «выгорания» (адаптация Н.Е.Водопьяновой) и беседы с личным составом вышеуказанного подразделения, в котором приняли участие 56 сотрудников.

Профессиональное «выгорание» - совокупность негативных переживаний, связанных с работой, коллективом и всей организацией в целом. Чаще всего проявляется у специалистов, по роду деятельности взаимодействующих с другими людьми [3]. К.Маслач и С.Джексон рассматривают симптом выгорания как ответную реакцию на длительные профессиональные стрессы, возникающие в межличностных коммуникациях. [10, с. 9]. Выделяют следующие признаки профессионального выгорания [4, с. 10]:

1) эмоциональное истощение и, или физическое истощение, характеризуется состоянием безразличия, изнеможения (человек не может работать, как это было прежде);

2) деперсонализация (развитие негативного отношения к своим коллегам);

3) негативное профессиональное самовосприятие - ощущение собственной некомпетентности, недостатка профессионального мастерства.

Опросник «Профессиональное (эмоциональное) выгорание (MBI), адаптированный Водопьяновой Н.Е., состоит из 22 утверждений, связанных с периодичностью проявлений эмоциональных состояний в рабочей деятельности. Выводы можно сделать на основе субшкал, предложенных авторами методики: «эмоциональное истощение», «деперсонализация», «редукция персональных достижений». По результатам групповой диагностики количественный и качественный анализ вышеперечисленных критериев показал, что:

1) $87 \%$ сотрудников не отмечают у себя признаков эмоционального истощения, чувства апатии или постоянной усталости от работы. Несколько сниженный эмоциональный фон присутствуют у 13\% сотрудников, что связано с внешними факторами, такими как написание теста после ночной смены или другими объективными причинами, обозначенными в индивидуальной беседе с психологом.

2) 78\% тестируемых, удовлетворены своей профессией, взаимоотношениями с сослуживцами, возможностью профессионального и должностного роста. У $22 \%$ военнослужащих войск национальной гвардии отмечается развитие личностного отдаления в 
работе, проявляющееся в уменьшении количества контактов с окружающими, повышении раздражительности и нетерпимости в ситуациях общения, негативизме по отношению к другим людям.

3) $86 \%$ сотрудников, отвечая на вопросы теста, в целом удовлетворены своим профессиональным статусом, позитивно оценивают свою работу. 14\% сотрудников отметили снижение чувства компетентности в своей работе, недовольство собой, уменьшение ценности своей деятельности, негативное самовосприятие в профессиональной сфере.

По результатам исследования со всеми сотрудниками подразделения, имеющими признаки профессионального (эмоционального) выгорания проведен комплекс психокоррекционных мероприятий. С $13 \%$ сотрудников, у которых были выявлены сниженный эмоциональный фон, признаки эмоционального истощения, проведена индивидуальная психокоррекционная работа. В целях профилактики профессионального выгорания ведутся занятия по морально-психологической подготовке, тренинги, направленные на поддержание благоприятного социально-психологического климата в коллективе, обучение методам саморегуляции, навыкам бесконфликтного общения.

Таким образом, основные факторы эмоционального выгорания сотрудников подразделения связаны с социальными аспектами службы: взаимодействием с сослуживцами, негативном самовосприятии деятельности, уровнем компетентности, профессионализма сотрудников, удовлетворенностью условиями службы, решением социально-бытовых вопросов; уровнем коллективного настроения и его динамикой [8, с7.]. Гипотеза исследования состоит в том, что общее состояние социально-психологического климата в коллективе влияет на уровень профессионального выгорания отдельных сотрудников изучаемого подразделения.

Мониторинг состояния социально-психологического климата в коллективе проводится согласно плана-графика, утвержденного руководителем изучаемого подразделения Федеральной службы войск национальной гвардии Российской Федерации. Плановое изучение социально-психологического климата в исследуемом коллективе состоялось после диагностики уровня профессионального выгорания сотрудников и комплекса мероприятий психокоррекционной работы.

Во втором квартале 2017 года проведено плановое исследование социальнопсихологического климата в подразделении. Изучение проводилось путем анонимного анкетирования и беседы с личным составом вышеуказанного подразделения, в котором приняли участие 49 сотрудников, что составляет $71 \%$ от личного состава. По результатам исследования был сделан вывод, что социально-психологический климат в подразделении характеризуется, как «среднеблагоприятный». Основные вопросы, заявленные в анкетировании социально-психологического климата, направлены на изучения степени удовлетворенности сотрудников взаимоотношениями в коллективе с коллегами, руководством. Также выясняются социальные проблемы. Оценка степени удовлетворенности сотрудниками профессиональной деятельностью изучалась по группам критериев, которые затрагивают материальные, бытовые, технические и служебные вопросы. По результатам анкетирования в вышеуказанном подразделении, сотрудники больше всего ценят стабильность и уверенность в завтрашнем дне, возможность принести пользу обществу и государству, возможность ранней пенсии, возможность заниматься любимым делом, реализовывать свое профессиональное призвание. В итоге опрошенные сотрудники удовлетворены содержанием выполняемых обязанностей, эффективностью профессиональной деятельности, хорошими взаимоотношениями с сослуживцами и с непосредственным руководителем.

В работе представлены результаты исследования социально-психологического климата как подтверждение эффективности профилактики эмоционального выгорания сотрудников Войск национальной гвардии Российской Федерации, своевременной диагностике, психокоррекции негативных симптомов выгорания. Эти и другие факторы нельзя не учитывать, говоря о профессиональном выгорании личности сотрудника. Именно, 
благоприятные отношения в служебном коллективе, дружеская атмосфера доверия и поддержки позволяют чувствовать уверенность и стабильность личному составу в нелегкие служебные будни.

\section{Литература}

1. Башенкова Л.А. Диагностика симптома эмоционального выгорания, и мероприятия, направленные на его предупреждение / Л.А. Башенкова //Среднее профессиональное образование. - 2015. №11.;

2. Борисова С.Е. Профессиональная деформация личности сотрудника // Энциклопедия юридической психологии/ Под. общ. ред. Проф. А.М. Столяренко. М.: ЮНИТИ-ДАТА, Закон и право,2003.

3. Водопьянова Н.Е. Синдром выгорания: диагностика и профилактика / Н.Е. Водопьянова, Е.С. Котова Е.В.

4. Котова Е.В. Профилактика синдрома эмоционального выгорания: учебное пособие [Электронный ресурс]. - Электрон. дан. /Краснояр. гос. пед. ун-т им. В.П. Астафьева. Красноярск, 2013. Старченкова. - 2-е изд. - СПб.: Питер, 2009.- 336с.;

5. Организация работы кабинета психологической регуляции в органах внутренних дел. Учебно-методическое пособие. - М.: ЦОКР МВД России, 2007. -232 с.;

6. Профилактика профессиональной деформации личности сотрудника органов внутренних дел: Методическое пособие /Под общ. Ред. В.М. Бурыкина - М.: ИМЦ ГУК МВД России, 2004.-144c.;

7. Самоукина Н.В. Психология профессиональной деятельности : учеб.пособие для студентов непсихологич. высш.учеб.заведений / Н.В. Самоукина. - СПб.: Питер, 2004. -219с.;

8. Социально-психологический климат в служебных коллективах ОВД: Методическое пособие / Е.В. Лапшин, Е.Е. Чапко (составители) /Под ред. М.И. Марьина, 2001.;

9. Чутко Л.С. Синдром эмоционального выгорания. Клинические и психологические аспекты / Л. С. Чутко, Н. В. Козина. - 2-е изд. - М. : МЕДпресс-информ, 2014. - 256 с.

Князькова М.Г., Пшеничный Д.К.

\section{ПРОБЛЕМА МОРАЛЬНО-ПСИХОЛОГИЧЕСКОЙ СОСТАВЛЯЮЩЕЙ ИСКУССТВЕННОГО ИНТЕЛЛЕКТА В СОВРЕМЕННЫХ ТЕНДЕНЦИЯХ ЗАМЕНЫ ЮРИСТА}

В настоящее время юристы курируют широкий комплекс вопросов и задач, которые поставлены перед ними человеком, обществом и государством. Находясь на переднем плане во взаимодействии с человеком, обществом, юристы должны отличаться нравственной безупречностью.

На протяжении всех исторических этапов функционирование и развитие правовой деятельности была и останется актуальной задача создания профессионального, компетентного, патриотически воспитанного, морально и психологически устойчивого юриста.

Морально-психологическая подготовка является основной формой моральнопсихологического обеспечения в правовой сфере, также является одним из основных эффективных путей развития профессионально-личностных качеств юриста.

Морально-психологическая подготовка основывается на формировании и развитии у юриста понятия и принятия общественных принципов и взглядов о хорошем и плохом, правильном и неправильном, добре и зле, совокупности норм поведения, которые вытекают из этих представлений, а также в развитии психологических способностей общения, убеждения, взаимодействия с обществом и отдельными людьми в юридической практике.

Высокий рейтинг Дональда Трампа на выборах в среде американских семей со средним и низким уровнями доходов были в некоторой степени обусловлены убежденностью населения 
США в том, что он остановит темпы изменений на рынке труда, где рабочие места «голубых воротничков» модернизируются с учетом автоматизации и глобализации, все это становится возможным в период современного прогресса в области технологий.

Кроме того, призывы социалистов революционной и советской эпохи в духе лозунга «от каждого по способностям, каждому по потребностям», зачатки которого заложены в «Кодексе природы» Этьенна-Габриэля Морелли, обращают внимание на недавний референдум в Швейцарии и инициативу по обеспечению гарантированного гражданского дохода, которая набирает обороты во всем развитом мире и получила на сегодняшний день свою реализацию, например, в Финляндии. [1] [2]

Многие традиционные профессии прошлого стали жертвами автоматизации, развития роботов и прорывов в технологиях искусственного интеллекта. Повлияет ли технический прогресс на профессию юриста? Можно ли заменить современного юриста искусственным интеллектом. Данные вопросы являются дискуссионными на современном этапе развития психологии, этики, юриспруденции.

Юрист, считается весьма консервативной профессией, характеризующейся в сознании большинства российского населения с документами, формализованным языком. Современные цифровые технологии уже подвергли изменению структуру юридического сектора: развиваются новые способы управления людьми и информацией, а значит, и правовая практика в целом. На сегодняшний день от этого в основном выиграли адвокатские и нотариальные конторы, с которых была снята необходимость в принятии на работу помощников, имеющих юридическое образование.

Но прорывы в программном обеспечении таких фирм, как IBM, ROSS и RAVN привнесли серьезные изменения в стандарт юридической практики. Готовность к использованию такого программного обеспечения и технологий может оказать влияние на пересмотр требований, предъявляемых к правовому сектору. Также могут возникнуть вопросы относительно уровня владения юристами данными технологиями. Способность использовать искусственный интеллект в конечном итоге может стать необходимым стандартом юридической профессии.

Обратимся к анализу существующих программ.

IBM Watson - суперкомпьютер фирмы IBM, оснащённый вопросно-ответной системой искусственного интеллекта, созданный группой исследователей под руководством Дэвида Феруччи. Его создание- часть проекта DeepQA. Основная задача Уотсона- понимать вопросы, сформулированные на естественном языке, и находить на них ответы в базе данных. [3] Назван в честь первого президента IBM- Томаса Уотсона. [4] На основе IBM Watson была разработана система искусственного интеллекта ROSS, которая сейчас находит широкое применение в деятельности российских и западных юридических фирм.

RAVN - это новейшая платформа искусственного интеллекта, которая позволяет нескольким приложениям автоматически организовывать, обнаруживать и обобщать ваши документы. [5] RAVN-платформа задает темп на рынке, ее используют различные типы организаций для повышения эффективности, увеличения производительности и снижения рисков.

Функции искусственного интеллекта платформы RAVN довольно просты. Кратко механизм работы платформы может быть описан как ввод в систему определенного набора данных и моментальное получение на выходе разрешения того или иного вопроса в области права.

На самом деле, данная платформа позволяет ряду приложений автоматически читать, интерпретировать и обобщать ключевую информацию из документов и неструктурированных данных и, как говорят, в состоянии обрабатывать тысячи контрактов в считанные секунды.

Это, по сути, компьютер, выполняющий ключевые функции юриста, обрабатывающий неструктурированные данные и проводящий их экспертизу. 
Достаточно указать подробности гражданского или уголовного дела в RAVN, и программа сможет определить шансы на успех и показать наилучший из возможных результатов рассмотрения дела в суде.

Однако в результате этих нововведений могут возникнуть этические вопросы к поведению юристов.

Так, грядущие изменения могут быть вредны для адвоката. И поэтому адвокаты могут проигнорировать сигналы искусственного интеллекта, где он, например, укажет на малую вероятность успеха в судебном разбирательстве. Основополагающие цели Федерального закона от 31.05.2002 № 63-Ф3 «Об адвокатской деятельности и адвокатуре в Российской Федерации», а также Кодекса профессиональной этики адвоката базируются на приоритете защиты и продвижения интересов клиента.

Однако указанные акты могут вскоре настаивать на оценке перспектив успеха с помощью ROSS или RAVN. Это может вызвать эффект внедрения так называемых «безжалостных приложений».

Вместо того, чтобы полагаться на адвокатов, для определения своего шанса на успех, истцы, ответчики по гражданским делам, подозреваемы и потерпевшие по уголовным делам скоро смогут надеяться на программное обеспечение, которое не может иметь заинтересованности в исследовании и расследовании объективных обстоятельств дела. Зачем защищать свои права, законные интересы и требования, если технология искусственного интеллекта говорит, что шансы на успешный исход дела нулевые?

Таким образом, многие юристы опасаются, что внедрение искусственного интеллекта может оказать решающее воздействие на пересмотр перечня обязанностей юриста, уменьшив их доход, с одной стороны и, представить собой угрозу замены юриста - с другой.

McKinsey Global Institute выяснил, что в настоящее время 23 процента работы юриста могут быть автоматизированы, и можно предположить, что эта цифра будет постепенно увеличиваться. [4]

Введение технологии искусственного интеллекта, может потребовать внесений изменений и соответствующих дополнений в российское законодательство.

Однако эти изменения, надо полагать, не смогут повлечь перехода на искусственный интеллект, заменив работы специалиста, имеющего высшее юридическое образование. Думается, что искусственный интеллект призван усовершенствовать работу профессионального юриста, но не заменить его. Как все отрасли стремятся к эффективности, так и правовое поле нуждается в оптимизации. Вполне вероятно, что данный процесс позволит сделать профессию юриста более продуктивной и эффективной.

Так, современная больница использует искусственный интеллект в медицинской диагностике, что представляет собой большой прогресс в оказании медицинской помощи. Юристы должны принять подобное положение дел как возможность улучшить свою профессию.

По мере преодоления недостатков профессии, юристы получат более четкое представление о роли информационных технологий в своей практики. Технологии станут не заменой юристам, а толчком к развитию более предсказуемой правовой системы с более широким доступом к правосудию.

Поэтому, если технологическое развитие сочетается с политическими настроениями, которые восприимчивы к потребностям людей, то достижения, предлагаемые этими промышленными разработками, могут быть использованы и с учетом интересов различных социальных слоев, в том числе, интересов юристов.

\section{Литература}

1. Морелли, Э-Г. Кодекс природы, или Истинный дух её законов / Э-Г. Морелли. - М.: Л., 1956.

2. Burchakov, А. «Добро пожаловать в посттрудовую экономику». Обозреватель Fast Company о безусловном базовом доходе. /A.Burchakov // -Режим доступа: https://vc.ru/14349- 
postwork-economy Smartest Machine on Earth. - Режим доступа: http://documentarystorm.com/science-tech/smartest-machine-on-earth

3. Hale, M. Actors and Their Roles for \$300, HAL? HAL! / Mike Hale // The New York Times. - 2011. - 8 Февраля. - C. 5.

Ravn ACE. - Режим доступа: http://ravn.co.uk

4. Технологии, которые (не) могут лишить нас работы. Примеры из 15 сфер деятельности. - Режим доступа: https://www.awaragroup.com/ru/blog/technologies-that-will-notsteal-our-jobs/\#_edn40

5. Анцыферова, Л.И. Связь морального сознания с нравственным поведением человека (по материалам исследований Лоуренса Колберга и его школы) [Текст] / Л.И. Анцыферова //Психологический журнал. - 2009. -Т. 20. - № 3. - С.5 - 17.

Курияов Н.А.

\section{ПСИХОЛОГИЧЕСКИЕ КРИТЕРИИ БЕЗОПАСНОЙ ОБРАЗОВАТЕЛЬНОЙ СРЕДЫ ДОУ}

На данном этапе развития общества важнейшим условием решения основных задач, как страны, так и мира в целом, является обеспечение безопасного и благоприятного детства. В противовес этому сохраняется проблема психологического и физического насилия над детьми. Несмотря на законодательство, социальную рекламу и выпуски по телеканалам о насилии над детьми, до сих пор сохраняется эта проблема.

Обеспечение психологической безопасности в ДОУ, а также охрана и поддержание физического и психического здоровья участников образовательной среды, а также противодействие и профилактика психологического и физического насилия должны быть приоритетными направлениями в работе образовательного учреждения.

В связи с этим изучение критериев безопасной образовательной среды является актуальным. Выделение критериев безопасности в образовательной среде поможет педагогам регулировать свою профессиональную деятельность и поведение и организовывать среду с учетом безопасности для ее участников.

В современном понимании, образовательная среда - это психолого-педагогическая реальность, сочетание уже сложившихся исторических влияний и намеренно созданных педагогических условий и обстоятельств, направленных на формирование и развитие личности ученика[1, с. 79]. Образовательная среда характеризуется искусственно созданным пространством, в котором с различной степенью организованности происходит процесс развития личности. Образовательная среда создается и поддерживается ее участниками субъектами. Субъектами образовательной среды ДОУ выступают педагогический состав, воспитанники и родители.

По определению И.А. Баевой, психологическая безопасность образовательной среды - это состояние образовательной среды, свободное от проявления психологического насилия, удовлетворяющее потребности в доверительном общении и характеризующееся позитивным отношением к ней участников образовательного процесса [1, с. 83].

Рубцов В. В. выделяет следующие критерии безопасной среды: качество межличностных отношений; защищенность; эмоциональная комфортность; удовлетворенность. [3, с. 4]

С точки зрения безопасности, качество межличностных отношений характеризуется в доброжелательном, безоценочном отношении и психологическом принятии; защищенность в отсутствии всех форм насилия, как физического, так и психологического; эмоциональная комфортность - в отсутствии тревожности, проявлении интереса к учебно-воспитательному процессу, отсутствии негативных переживаний; удовлетворенность - в осознании того, что учебно-воспитательный процесс был эффективен. 
Говоря о безопасной образовательной среде, имеется в виду не только безопасность воспитанников, но и педагогов и родителей.

Основной угрозой во взаимодействии участников учебно-воспитательного процесса является получение психологической травмы, в результате которой наносится ущерб позитивному развитию и психологическому здоровью, отсутствует базовое удовлетворение основных потребностей, т. е., возникает препятствие на пути самоактуализации [2, с. 56].

Выделяют следующие проявления психологического насилия: унижение, оскорбление, высмеивание, угрозы, принуждение сделать что-либо против своего желания, игнорирование, неуважительное отношение, недоброжелательное отношение. Угрозой психологической безопасности является непризнание референтной значимости образовательной среды ее участниками и, как следствие, реализация намерения ее покинуть или отрицание ее ценностей и норм.

Угрозой психологической безопасности выступает и отсутствие удовлетворенности основными характеристиками процесса взаимодействия всех участников учебновоспитательного процесса, так как именно в нем содержатся возможности и условия, обеспечивающие личностное развитие. Эмпирическими проявлениями здесь служат: эмоциональный комфорт, возможность высказать свою точку зрения, уважительное отношение к себе, сохранение личного достоинства, возможность обратиться за помощью, учет личных проблем и затруднений, внимание к просьбам и предложениям [1, c.85].

С целью изучения критериев безопасной образовательной среды ДОУ было проведено исследование в муниципальном дошкольном образовательном бюджетном учреждении «Детский Сад» №93 г. Сочи. В исследовании приняло участие 15 педагогов, 40 родителей, 23 воспитанника подготовительной группы в возрасте 6-7 лет.

Вначале изучался психологический климат в педагогическом коллективе, как оценка удовлетворенности взаимоотношениями внутри педагогического коллектива. Была использована методика Л. Н. Лутошкина «Определение психологического климата группы».

Результатом данной методики было получение представление педагогов о свойствах, способствующих сплоченности или противодействующие ей. Так педагоги отмечают, что в их коллективе преобладает благоприятный социально-психологический климат (среднее 32,26667). Положительными особенностями, способствующими сплоченности и благоприятному психологическому климату педагоги выделяют «участие в совместных делах» (12 человек); «одобрение и поддержка, упреки и критика высказываются с добрыми побуждениями» (10 человек) и «участливое и доброжелательное отношение к новым членам, помощь им в освоении» (7 человек). Отрицательными особенностями - «равнодушие остальных членов к успехам или неудачам всего коллектива» (5 человек).

Таким образом, отношение педагогов к психологическому климату внутри коллектива оценивается как благоприятное.

Для изучения детской тревожности, как косвенного показателя психологической небезопасности была проведена методика «Выбери нужное лицо» Р. Тэммла. Ее результатом явилась оценка субъективного эмоционального опыта в конкретных и подобных им ситуациях.

Для данного исследования были интересны ситуации, моделирующие отношения ребенокребенок и ребенок-взрослый. В ситуациях ребенок - ребенок («Игра с младшими детьми», «Объект агрессии», «Игра со старшими детьми», «Агрессивное нападение», «Изоляция») эмоционально негативные выборы сделало 8 детей, (34,7\%), а также 12 детей $(52,1 \%)$ сделали негативные выборы по тем или иным ситуациям из данной категории. В ситуациях ребенок-взрослый («Ребенок и мать с младенцем», «Выговор», «Игнорирование», «Ребенок с родителями») эмоционально негативные выборы сделало 3 ребенка (13\%), 6 детей (26\%) сделали негативные выборы по тем или иным ситуациям.

На основании этого можно сделать вывод, что для данной группы детей наименее безопасным взаимодействием является ребенок-ребенок, нежели ребенок-взрослый. 
Методикой оценки безопасности образовательной среды выступила анкета-опросник «Психологическая диагностика учебно-воспитательной среды» разработанной И.А. Баевой [1 с. 188]. Некоторые пункты опросника были изменены под действительность детского сада.

Данное исследование показало, что большинство субъектов взаимодействия в образовательной среде относятся к ней позитивно.

В первой части опросника вычисляется индекс удовлетворенности образовательной средой.

В группе воспитанников позитивное отношение составляет $82,6 \%$, в группе воспитателей - 87\%, в группе родителей $77 \%$. В сравнении с педагогами $(6 \%)$ и воспитанниками $(8 \%)$ более высокий уровень негативного отношения к среде у родителей (14\%).

В ходе исследования было выявлено, что общими для всех субъектов взаимодействия и наиболее важными характеристиками образовательной среды являются: взаимоотношение с педагогами $89 \%$ всех опрошенных, взаимоотношения с воспитанниками $-81 \%$ и эмоциональный комфорт - 84\%.

По этим трем характеристикам наиболее удовлетворены воспитанники. Средняя их оценка взаимоотношений с педагогами среднее арифметическое по пятибалльной шкале составила 4,1, 3,7 - с воспитанниками и 3,9 - эмоциональный комфорт. Наименьшие показатели удовлетворенности воспитанниками получили характеристики учет личных проблем и затруднений $(2,9)$ и внимание к просьбам и предложениям (3.2).

В группе педагогов наиболее удовлетворяющими характеристиками образовательной среды выступили взаимоотношения с воспитанниками $(3,5)$, эмоциональный комфорт $(3,7)$ и уважительное отношение к себе $(3,4)$. Наименее удовлетворительными - возможность проявлять инициативу $(2,7)$, возможность высказать свою точку зрения $(2,1)$ и помощь в выборе собственного решения $(2,9)$.

Для группы родителей наиболее удовлетворительными характеристиками являются взаимоотношения с воспитателями $(3,7)$, сохранение личного достоинства $(3,6)$ и уважительное отношение к себе $(3,6)$. Наименее удовлетворительными характеристики явились учет личных проблем и затруднений (2.3), возможность высказать свою точку зрения $(2,1)$ и внимание к просьбам и предложениям $(2,0)$.

Индекс удовлетворенности образовательной средой, как общая оценка значимых характеристик, находится на среднем уровне у родителей $-0,46$ и педагогов $-0,52$. На высоком уровне - у воспитанников - 0,8.

Во второй части опросника исследуется индекс психологической безопасности образовательной среды. Он определяется уровнем защищенности от психологического насилия во взаимодействии субъектов.

Наименее защищенными от психологического насилия чувствуют себя воспитанники. Анализ данных показателей выявил, что воспитанники наименее чувствуют себя в безопасности с другими детьми (2,2 - средний уровень с тенденцией к ниже среднего). C воспитателями воспитанники чувствую себя более защищенными (3 - средний с тенденцией к высокому).

У педагогов показатели психологической защищенности в ситуациях взаимодействия с воспитанниками, коллегами, и администрацией находятся на среднем уровне с тенденцией к высокому $(2,8)$. При этом наименее защищенными они чувствуют себя во взаимодействии с администрацией (1.8 - средний уровень с тенденцией к ниже среднего).

Показатели защищенности у родителей свидетельствуют о среднем уровне с тенденцией к высокому $(3,0)$.

Таким образом, показатели психологической безопасности во всех трех группах испытуемых находятся на среднем уровне.

Обобщая полученные результаты, стоит отметить, что воспитанники, педагоги и родители удовлетворены образовательной средой ДОУ. Также родители и педагоги чувствуют себя защищенно в детском саду. Однако дети испытывают недостаток защищенности во взаимодействии с другими детьми. 


\section{Литература}

1. Баева И. А. Б 15 Психологическая безопасность в образовании: монография. СПб.: Издательство «СОЮЗ», 2002. 271 с. ISBN 5-94033-148-3

2. Коджаспиров А.Ю., Коджаспирова Г.М. Издательство "Проспект",. 2017 г. С: 460

3. Рубцов В. В., Баева И. А., Гаязова Л. А. Обеспечение безопасности образовательной среды: комплексный подход // Психологические проблемы безопасности в образовании: Материалы Всероссийской научно-практической конференции с международным участием /Под ред. И. А. Баевой, В. В. Рубцова. М.: МГППУ, 2011. Т. 1. С. 3-7.

4. Столяренко Л.Д. Основы психологии. Ростов н/Д: Изд-во «Феникс», 1997. С. 554.

Макаревская И.Г.

\section{ПСИХОЛОГИЧЕСКИЕ ПРЕДПОСЫЛКИ БЕЗОПАСНОСТИ ДИАГНОСТИЧЕСКОГО ПРОЦЕССА В СИТУАЦИИ КЛИЕНТА И В СИТУАЦИИ ЭКСПЕРТИЗЫ}

В последнее время можно говорить о высокой актуальности и разработанности в психологической науке и практике проблемы психологической безопасности личности. В нашем исследовании мы предприняли попытку рассмотреть такой контекст проблемы психологической безопасности, как безопасность психодиагностического процесса.

Одним из основных этических принципов психодиагностики является принцип обеспечения безопасности деятельности испытуемого в ситуации оценки его личности. Обеспечение безопасности в контексте психодиагностического процесса означает, что психолог-диагност использует только те методики и методические приемы диагностики, которые не являются опасными для физического и психического здоровья испытуемого, не оказывают значимого влияния на его эмоциональное состояние, позволяют получать достоверную информацию, не представляют испытуемого в результатах исследования в ложном, искаженном свете, не дают сведений о тех его психологических свойствах и особенностях, которые не имеют отношения к конкретным, согласованным задачам психологического исследования [4].

При этом практика психодиагностической деятельности современного психолога показывает, что декларируемое правило безопасности деятельности испытуемого считается априори реализуемым в ходе психологического исследования в том случае, если психодиагност использует классические, прошедшие психометрическую проверку методики. Но психологическое измерение, это, прежде всего, процесс взаимодействия измерителя и измеряемого, со всем контекстом процесса измерения. В каждом новом контексте измерения человек проявляет себя соответственно. Результаты любого психологического измерения опосредуются взаимодействием между измеряемым свойством, методом, процедурой измерения и объектом измерения. При этом в психологии объект измерения - динамичен, изменчив, и что самое важное, обладает набором характеристик, способных значимо повлиять на результаты исследования, внести искажения в получаемые результаты. Ранее в наших исследованиях было показано, что ситуация тестирования достижений и специальных способностей способна значимо повлиять на эмоциональное состояние испытуемого, его самочувствие, активность, настроение, ситуативную тревожность. Таким образом, можно предполагать, что контекст процедуры измерения, ситуация тестирования способна значимо опосредовать получаемые результаты, нарушая, тем самым, требования к безопасности процедуры психологического измерения.

В данном исследовании мы предприняли попытку рассмотрения такого психологического аспекта безопасности деятельности испытуемого, как прогноз успешности деятельности в ситуации экспертизы и в ситуации клиента. 
В статье сравниваются две ситуации измерения - «ситуация экспертизы» и «ситуация клиента», для того, чтобы проанализировать, существуют ли особенности персонального прогноза успеха ситуации тестирования в зависимости от характера самой ситуации.

Мы предполагаем, что адекватность прогноза испытуемым исхода ситуации тестирования, как в «ситуации экспертизы», так и в «ситуации клиента» может предопределять возможность управления собственной деятельностью, снимая неопределенность будущих событий и снижая, таким образом, напряженность и ситуативную тревожность, что является одним из компонентов психологической безопасности тестирования.

Для проверки того, насколько точным может быть прогноз исхода ситуации тестирования в «ситуации клиента» и в «ситуации экспертизы» мы инициировали исследование, в котором испытуемых просили дать прогноз относительно результата тестирования учебных и профессиональных достижений в «ситуации клиента» и в «ситуации экспертизы» [5]. Всего в исследовании приняло участие 300 человек.

Адекватность и направленность неадекватности персонального прогноза успеха в ситуации тестирования достижений изучались нами через выявление сдвига между реальным результатом, полученным испытуемым в ходе тестирования и прогнозируемыми оценками, определяемыми испытуемыми перед началом тестирования.

В результате было выделено несколько групп испытуемых: испытуемые, чей персональный прогноз успеха в ситуации тестирования соответствовал реально полученным результатам; испытуемые, прогнозирующие результат, соответствующий более низким значениям, чем реально полученные; и испытуемые, чей прогноз успеха соответствовал результатам большим, чем были получены в реальности.

Статистическая обработка с использованием критерия U-Манна-Уитни показала, что существуют значимые различия в адекватности персонального прогноза успеха в «ситуации экспертизы» и «ситуации клиента». (при $\mathbf{p} \leq 0,001$ ).

В «ситуации клиента» большее количество испытуемых дает адекватный прогноз относительно возможного успешного исхода ситуации тестирования, в «ситуации экспертизы» большинство испытуемых демонстрирует тенденцию к занижению прогнозируемого результата по сравнению с реальным.

Знание ситуативных детерминант, влияющих на адекватность персонального прогноза успеха при тестировании достижений в «ситуации экспертизы» и «ситуации клиента» позволяет, на наш взгляд, определить пути компенсации и коррекции «тревоги оценивания», возникающей в ходе тестирования и повышает доверие к результатам тестирования, выступая определенной предпосылкой безопасности психодиагностического процесса.

Перспективным нам представляется дальнейшее изучение поставленной проблемы, и, в частности, анализ того, как проблема «безопасности-опасности» психодиагностического исследования репрезентируется в представлении испытуемых в «ситуации экспертизы» и в «ситуации клиента».

\section{Литература:}

1. Белова О.В. Общая психодиагностика. Методические указания. - Новосибирск: Научно-учебный центр психологии НГУ, 1996

2. Дружинин В.Н. Структура и логика психологического исследования /Ин-т психологии РАН. - 2-е изд., испр. - М., 1994. - 163 с

3. Зароченцев К.Д., Худяков А.И. Кризис современной психодиагностики// Философия и проблемы человека. СПб., 1997.

4. Крылов А.А., Юрьев А.И. Этические принципы и правила работы психолога // В кн.: Практикум по общей и экспериментальной психологии» /Под ред. Крылова А.А., Маничева С.А., 2- е изд.-е, СПб., Москва, Харьков, Минск, 2000. С.545-552

5. The Adequacy Of Personal Success Prediction In Psychological Achievement Testing//U.E. Makarevskaya, I.G. Makarevskaya, Z.I. Ryabikina// The European Proceedings of Social \& Behavioural Sciences EpSBS, e-ISSN: 2357-1330, 2017 Published by the Future Academy, p.227234 


\section{СООТНОШЕНИЕ ТИПОВ ПАПИЛЛЯРНЫХ УЗОРОВ И ТИПОВ НС: ВОЗМОЖНОСТИ ИСПОЛЬЗОВАНИЯ В ЭКСПЕРТНО-ПСИХОЛОГИЧЕСКИХ ИССЛЕДОВАНИЯХ}

С каждым годом круг деятельности психологов все больше увеличивается. Одним из направлений их практической деятельности является экспертная деятельность.

В целях получения «доброкачественного» заключения, отвечающего требованиям допустимости, достоверности и полноты, исследование должно проводить лицо, обладающее специальными познаниями и соответствующей квалификацией, - эксперт.

Для исследования особенностей поведения человека, его целей, мотивов, состояний в рамках гражданских, уголовных дел назначают проведение судебно-психологических, комплексных психолого-психиатрических, психолого-почерковедческих, психологоискусствоведческих экспертиз. Применение психологических знаний при рассмотрении гражданских и уголовных дел позволяет оптимизировать процесс судебного разбирательства и способствует отправлению правосудия.

Итак, под психологической экспертизой принято понимать исследование психики человека и особенностей его поведения. Предметом психологической экспертизы является психика человека. Объектом исследования при проведении экспертизы является сам человек, а также продукты его творчества и деятельности, такие как дневники, письма, записки, аудио- и видеозаписи.

В зависимости от правового статуса подэкспертных и тех вопросов, которые решаются в рамках исследования, можно выделять различные классы психологических экспертиз. Процессуально-правовое положение испытуемых дает основание для выделения судебнопсихологических экспертиз потерпевшего, подозреваемого, свидетеля и обвиняемого. Ряд вопросов, решаемых судебно-психологической экспертизой, позволяет классифицировать психологические экспертизы по направлениям. В этой связи можно выделить экспертизу психических процессов, в ходе которой исследуются особенности восприятия, мышления, памяти, воображения и т.д.; экспертизу психологических состояний, изучающую волевые, познавательные, эмоциональные составляющие; экспертизу психологических свойств, таких как характер, темперамент, свойства НС, способности.

В делах о нарушении половой неприкосновенности личности, убийствах, посягательствах на общественное имущество граждан необходимо участие психолога.

В настоящее время становится все более актуальным проведение комплексной психологолингвистической экспертизы по делам о возбуждении ненависти и вражды, об экстремистской деятельности, о взыскании морального вреда.

Психолого-фоноскопическую экспертизу аудио- и видеодокументов также могут назначить суд и органы дознания и следствия.

Результаты психологической экспертизы закрепляются в экспертном заключении, которое обладает доказательной силой в суде.

Важное значение в экспертно-психологических исследованиях имеет фиксация стабильных характеристик личности для решения юридически значимых вопросов.

Предлагаем изучение типа НС как неизменной характеристики, дающей более точную интерпретацию поведения субъекта, чем изменяющиеся (например, такие как эмоциональное состояние, характерологические особенности, познавательные способности).

Также в ряду стабильных характеристик личности интересно рассмотреть типы папиллярных узоров, не только в связи с тем, что это неизменная характеристика, но потому, что подэкспертный не всегда может присутствовать на экспертизе по различным обстоятельствам, а его отпечатки пальцев могут иметься в наличии.

Данное исследование было направлено на изучение связи между устойчивыми индивидуальными биологически обусловленными особенностями личности. Это 
особенности, связанные с индивидуальными проявлениями основных свойств нервной системы и типа папиллярных узоров. И если нет возможности проводить экспериментальные пробы для изучения типа НС, то взаимосвязь данных характеристик может дать информацию о подэкспертном без его личного присутствия.

Практическая часть работы включала 2 этапа:

1) диагностический (формирование выборки, определение свойств НС испытуемых, дактилоскопия);

2) математико-статистическая обработка, анализ, интерпретация эмпирических данных.

Объем выборки составил 33 чел. Это люди разного пола, возрастом от 20 до 50 лет.

На диагностическом этапе применялись методы: экспериментальные пробы, дактилоскопия.

В ходе экспериментальных проб (теппинг-тест) были определены типы нервной системы испытуемых.

Дактилоскопия (добровольная) проводилась следующим образом:

1. На чистые и сухие пальцы рук валиком наносился тонкий слой краски.

2. На дактило-карточке равномерно «прокатавались» ногтевые фаланги, чтобы

рисунок отпечатался «развернутым».

В оттисках был соблюден порядок расположения пальцев.

После окончания процедуры, краску смывают с рук.

Полученные оттиски являются сугубо индивидуальными и никогда не повторяются, считаются устойчивыми анатомическими знаками конкретного лица.

Такая неизменность отпечатков исходит из генетических особенностей. При формировании плода в утробе, папиллярные линии уже сформировываются на пятом месяце. Они не меняются никогда. Рост и взросление человека ведет лишь к изменению пропорций.

Обработка результатов и их статический анализ были проведены в программе SPSS. Для сравнения эмпирических распределений между собой мы использовали критерий хи-квадрат. С помощью критерия хи-квадрат можно сравнивать распределения частот вне зависимости от их распределения, а также доказать, что в одном из уровней количество человек действительно больше или меньше.

Статистически значимых значений не обнаружено. Результаты ниже в таблице.

Соотношение типа НС и типа ПУ (таблица 1).

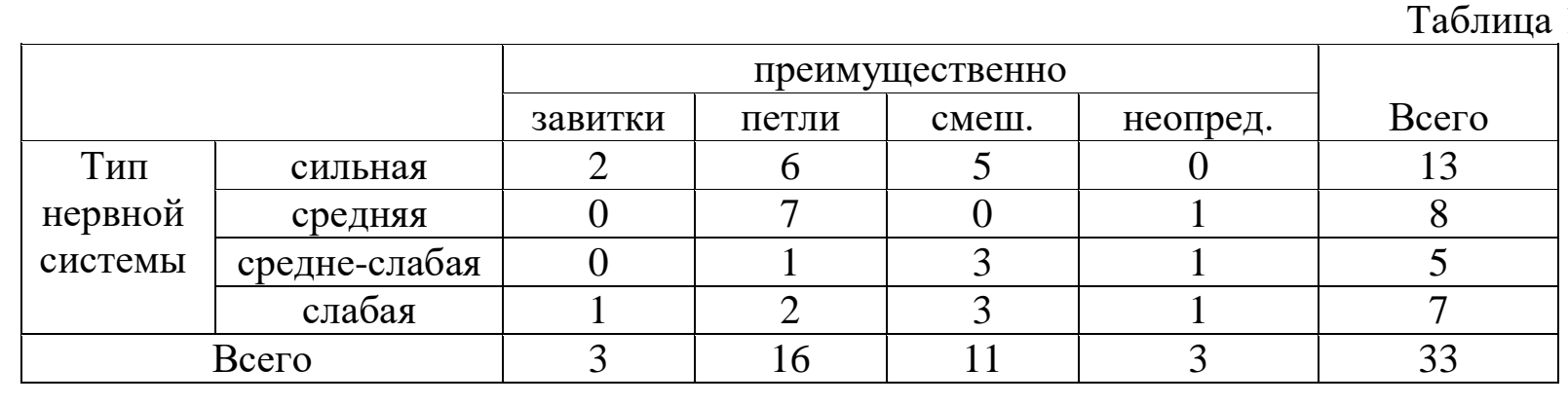

Исходя из данных таблицы, видно, что у людей с сильной НС преимущественно петлеобразный и смешанный тип ПУ, как и со средней НС - из 8 человек 7 человек с петлеобразным типом ПУ.

Статистическая обработка показала, только наличие тенденций, без значимых показателей по критерию хи-квадрат, что возможно, из-за небольшого количества выборки.

Выявленная тенденция показывает преобладание среди испытуемых сильной НС и петлеобразного типа ПУ.

Для уточнения результатов, скорее всего, следует увеличивать выборку, чтобы отследить статистически значимые значения между заданными переменными. 


\section{Литература}

1. Дворянчиков Н.В. Рецензия на учебник проф. Ф.С. Сафуанова «Судебнопсихологическая экспертиза» [Электронный ресурс] // Психология и право. 2015.

2. Енгалычев В.Ф., Шипшин С.С. Судебно-психологическая экспертиза. Методическое руководство. Калуга, 1996. 1991.

3. Коченов М.М., Теоретические основы судебно-психологической экспертизы, М.-

4. Макаревская Ю.Э., Соколова О.А., Пехова У.И. К постановке вопроса о соотношении психологических свойств личности и типов папиллярных узоров /ОТ ИСТОКОВ К СОВРЕМЕННОСТИ: 130 лет организации психологического общества при Московском университете: Сборник материалов юбилейной конференции: В 5 томах: Том 5 / Отв. ред. Богоявленская Д. Б. - М.: Когито-Центр, 2015. С. 214-217.

5. Небылицын В.Д. Изучение основных свойств нервной системы и их значение для психологии индивдуальных различий. / В.Д. Небылицын / Жизнь и научное творчество. - М.: Научно-издательский центр «Ладомир», 1996.

6. Самищенко С.С. Сравнительные исследования дактилоскопических формул человека // Закон и право. 2014.№ 11.

Петросьян С.H.

\section{ДЕВИАНТНОСТЬ КАК ТИП СЦЕНАРНОГО ПОВЕДЕНИЯ ЛИЧНОСТИ: СУБЪЕКТНО-БЫТИЙНЫЙ ПОДХОД}

Девиантность - это социологический термин, означающий тип поведения, отклоняющийся от общественных норм.

Девиантность часто отождествляется с преступным поведением, хотя девиантным можно считать любое поведение, не соответствующее нормативному, отклоняющемуся от общепринятых социальных стандартов.

Также, девиантное поведение не всегда носит отрицательный характер: развитие общественного сознания зачастую идет в направлении признания некоторых форм девиантного поведения, и присвоения таким формам поведения статуса нормы. Например, первые представительницы движения женской эмансипации воспринимались общественностью резко отрицательно. На сегодняшний день, самостоятельность, независимость и активность женщины в большинстве стран и культур считается нормативным, и даже социально одобряемым.

На сегодняшний день не существует целостного подхода к изучению девиантности, хотя накоплен фактический материал, позволяющий заключить, что при общем благополучии в жизни общества количество такого поведения у людей уменьшается. И наоборот, в обстановке социальной нестабильности, происходит рост количества людей с девиантными проявлениями. В таких случаях часто могут наблюдаться открытые демонстративные формы отвержения принятых социальных норм.

Считается, что девиантное поведение также можно воспитать в человеке. Например, если взросление ребенка будут проходить в среде, где существует насилие или аморальное поведение окружающих его индивидов. При взрослении такие дети могут выбирать криминальные методы достижения своих желаний.

К определенной группе девиантного поведения могут относиться люди, имеющие патологическую тягу к спиртным напиткам и наркотическим веществам, переданную им по наследству от родителей. К такой группе могут также относиться лица с наследственными психическими заболеваниями.

Считается, что чаще всего девиантные формы поведения выбирают для себя люди, не имеющие возможности нормальной самореализации в условиях социума. 
Субъектно-бытийный подход к личности (3.И. Рябикина) позволяет трактовать развитие ребенка как расширение личностной бытийности в отношениях Я-Мир, Я-Ты, Я-Они; и рассматривать динамику становления личности как этапы онтогенетически формирующейся со-бытийности, или некоего партнерства, где личностью осваиваются позиции в отношениях Я - Мир, Я - Ты (Другой), Я - Они (Другие).

Ситуация переживания угрозы подразумевает структурное выделение в событийной диаде двух позиционных полюсов, обладающих качеством полярной эмоциональной окрашенности: активного, воздействующего, связанного с угрозой, и пассивного, первоначально связанного с жертвенной позицией.

Позиция в отношениях, по мере взросления, закрепляется в психике субъекта как некий эмоционально-поведенческий стереотип поведения в условиях угрозы, либо условиях, воспринимаемых как угрожающие. В дальнейшем, такой стереотип поведения во многом формирует как линию поведения субъекта, систему его ценностей и предпочтений, так и общее направление жизни, в том числе, выбор стратегии поведения - социально приемлемого, либо социально отклоняющегося, девиантного.

В настоящее время нами разработан, апробирован и валидизирован опросник (внутренняя согласованность «альфа - Кронбаха» в целом по опроснику равна 0,93, ретестовая надежность - 0,85), диагностирующий степень выраженности диспозиционного реагирования, результаты которого могут быть представлены в виде индивидуального профиля диспозиционного реагирования.

Проведенное нами исследование, направленное на выявление профиля диспозиционного реагирования лиц, зависимых от ПАВ), позволяет нам утверждать, что для испытуемых, которым характерна зависимость от ПАВ, более свойственны проявления полюсов диспозиций: «Базовый страх», «Ненужность», «Жестокость», «Инфантилизм», «Власть», «Подчинение», «Подконтрольность», «Саботирующая подконтрольность», «Вина», «Подсудимость» и «Немощность».

Выраженность диспозиционного реагирования для лиц с зависимостью от ПАВ значительно выше, чем для обычных людей, что свидетельствует о большем эмоциональном напряжении зависимой личности.

В целом, людей с зависимостью от ПАВ можно охарактеризовать как более импульсивных (большая выраженность полюсов диспозиционного реагирования, выраженность полюса «Базовый страх»), конфликтных (выраженность полюсов «Власти», «Саботирующей подконтрольности»), безответственных («Инфантилизм») и социально неадаптивных («Вина», «Немощность»).

По результатам факторного анализа профилей диспозиционного реагирования на выборке из 219 человек, было выделено 4 фактора, охватывающих 67,2\% данных. Таким образом, были выделены четыре типа группирования видов диспозиционного реагирования, где один из четырех типов представляет выраженность (в порядке убывания) таких позиций реагирования, как Ненужность, Базовая агрессия, Равнодушие, Жестокость, Базовый страх, Обвинение, Саботирующее подчинение. Позиция Жестокости - по сути, это полюс позиционного реагирования в со-бытийной диаде Жестокость - Инфантилизм, предполагающий безнаказанное нарушение границ слабого.

Данный профиль диспозиционного реагирования описывает один из четырех типичных структур реагирования и может быть описан как тип личности, условно обозначенный, как «Жестокий».

Жестокий тип личности характеризуется выраженностью таких досознательных реакций, как базовая агрессия и базовый страх уничтожения. Это может свидетельствовать о крайней степени эмоциональной неуравновешенности и импульсивности. Одновременно, у такой личности не формируется качества привязанности и взаимосвязи как способности переживать самих себя в отношениях с другими. Такая личность, с большой вероятностью, будет эмоционально дистанцироваться от других, вместе с тем, страдая от ненужности. Одновременно, такой человек легко нарушает границы других людей, и склонен к активному 
неподчинению (позиции Саботирующее подчинение, Обвинение). Скорее всего, именно такой тип личности будет склонен к криминальному поведению.

Итак, первые исследовательские данные, полученные в результате применения авторского опросника профиля диспозиционного реагирования, позволяют предположить, что деструктивное девиантное поведение коррелирует с выраженностью диспозиционного реагирования досознательного уровня (диспозиции Базовая агрессия - Базовый страх, Равнодушие - Ненужность).

В свою очередь, выраженность диспозиционного реагирования начального уровня формирования личности, предполагает определенные алгоритмы формирования выраженности диспозиционного реагирования последующих уровней.

Таким образом, девиантный тип поведения личности, опирается на определенный способ реагирования, освоенный онтогенетически в со-бытийной диаде, является повторяемым, следовательно может быть отнесен к сценарным формам поведения личности.

\section{Литература}

1. Божович Л. И. (2008) Личность и ее формирование в детском возрасте. СПб. [и др.]: Питер.

2. Знаков В.В., Рябикина З.И. (2017) Психология человеческого бытия. М.: Смысл.

3. Петросьян С. Н. (2016 б) Диалектическая природа эмоционально-поведенческого реагирования в кризисной ситуации / Международный научно-исследовательский журнал Успехи современной науки,4, (4), с. $41-49$.

Самохвалова А.Г.

\section{ФОРМЫ ШКОЛЬНОГО НАСИЛИЯ КАК ФАКТОР ВОЗНИКНОВЕНИЯ КОММУНИКАТИВНЫХ ТРУДНОСТЕЙ ПОДРОСТКОВ, ПРОЖИВАЮЩИХ В ЗОНЕ ВОЕННЫХ ДЕЙСТВИЙ}

\section{Исследование проведено при финансовой поддержке РФФИ, проект № 17-06-00607- ОГН/18 «Коммуникативные трудности ребенка в поликультурной социальной среде: факторы возникновения и способы преодоления»}

Современный мир характеризуется огромным количеством различных стрессовокризисных ситуаций - военные конфликты, террористические акты, техногенные и природные катастрофы, чрезвычайные ситуации и др. На людей, находящихся в экстремальной обстановке, особенно в ситуациях военных действий, наряду с различными поражающими факторами действуют и психотравмирующие обстоятельства, представляющие собой комплекс сверхсильных раздражителей, вызывающих нарушение психической деятельности в виде так называемых реактивных состояний [1]. Переживание трудных жизненных ситуаций приводит к фрустрации базисной потребности в безопасности; препятствует эффективной социализации/индивидуализации личности в обществе; деформирует систему межличностных отношений и общения.

Критическая ситуация определяется как ситуащия невозможности, т.е. такая ситуация, в которой субъект сталкивается с невозможностью реализации внутренних необходимостей своей жизни - мотивов, стремлений, ценностей [3].

Несомненно, характер, динамика и интенсивность переживания критической ситуации будут различными у разных людей, будут зависеть от социальных и ситуационных характеристик, от индивидуально-типологических особенностей личности, ее опыта, готовности действовать в неблагоприятных условиях [7].

До недавнего времени было принято считать, что дети переносят экстремальные ситуации «легче», с меньшими эмоциональными затратами, т.к. имеют большее количество компенсаторных механизмов; у них реже проявляются стереотипные модели поведения; они чрезвычайно привязаны к значимым взрослым, что способствует их быстрому выходу из 
переживаний стрессогенной ситуации. Однако исследования показывают, что детские переживания кризисных ситуаций такие же насыщенные и тяжелые, как у взрослых [11; 14].

Война относятся к тем видам чрезвычайных ситуаций, от которых больше всего страдает подрастающее поколение. Дети являются самой незащищенной частью населения в ситуациях военных действий, так как практически лишены ресурсов для самозащиты. Основными травмирующими факторами в этом случае становятся - непосредственная угроза жизни и здоровью ребенка и его близких. Для детей дошкольного возраста наиболее типичными последствиями являются регрессивное поведение (энурез, страхи разлуки с родителями, страх перед незнакомыми людьми, утрата имеющихся навыков. У детей школьного возраста появляются проблемы в учебе и общении, поведенческие нарушения от агрессии до депрессии. Четко прослеживается «вина выжившего», отмечаются необоснованные соматические жалобы. При разлуке с родителями во время войны у детей отмечаются депрессия, неспособность испытывать удовольствие, нарушение эмоционального фона (дети не улыбаются) и социальных контактов [14].

Последствиями пережитых военных действий у одних детей являются постоянное присутствие травмы в сознании, сновидения о ней, кошмары, ожидание ее повторения (вздрагивание при малейших звуках), тяжелые психические состояния при напоминании о травме; у других - желание отдалить от себя воспоминания о травме, отказ ходить в школу, посещать места, где происходили военные действия, забывание важных событий, потеря смысла жизни, нежелание жить, общаться с другими людьми, болезненная привязанность к родителям [5].

Очень часто детям, проживающим в зонах военных действий, приходится менять место жительства, школу, круг общения. Новые социокультурные условия жизни оказывают сильное влияние на процесс самосознания личности, разрушают национальную идентичность, препятствуют самоутверждению, повышают уровень тревоги, враждебности и агрессивности, вызывают у ребенка ощущение страха, незащищенности, озлобленности [9]. Дети чрезвычайно остро переживают дезинтеграцию с родной для них общиной. А процесс формирования новой общины и адаптация к ней дается им очень трудно [7].

В условиях длительных военных действий под угрозой находится психологическая безопасность ребенка в образовательной среде, которая должна являться нормой жизни для современного человека и одним из индикаторов ее качества, наряду с удовлетворенностью и возможностями творчества и самореализации [2].

В кросс-культурном исследовании, проведенном нами в Российском провинциальном городе Костроме, где дети воспитываются в мирных социокультурных условиях, и в Украинском городе Луганске, где с 2014 года по настоящее время идут непрекращающиеся военные действия (только среди гражданского населения убито более 2450 человек, из них 42 ребенка в возрасте от нескольких месяцев до 16 лет, и около 9000 ранено), изучались формы психологического насилия, возникающие в действующих школах города, а также коммуникативные трудности подростков, обусловленные нарушением психологической безопасности ребенка в образовательном пространстве.

Школьное насилие - такой вид агрессии, при котором применяется силовое воздействие (физическое или психологическое) в межличностных отношениях детей, а также в отношениях между детьми и учителями [6]. К общим характеристикам школьного насилия можно отнести следующие:

- осуществляется в одиночку или группой людей (агрессоры);

- направлено против человека, который заведомо слабее психологически/физически (жертва);

- сопровождается применением силового воздействия (физического, психологического, эмоционального);

- носит систематичный и длительный характер [12].

Коммуникативные трудности рассматриваются нами как различной силы и степени выраженности объективные или субъективно переживаемые препятствия коммуникации, 
нарушающие внутреннее равновесие субъекта общения, усложняющие межличностные отношения; требующие внутренних усилий, направленных на их преодоление [10].

В исследовании проверялась гипотеза о существовании кросс-культурных различий в формах проявления школьного насилия и коммуникативных трудностей подростков, воспитывающихся в разных социокультурных условиях.

Выборку составили 310 подростков, из них 155 российских и 155 украинских. Каждая национальная группа включала в себя представителей мужского $(\mathrm{n}=73)$ и женского пола $(\mathrm{n}$ = 82) в возрасте 13-17 лет.

Методический дизайн исследования включал проективный метод незаконченных предложений, направленный на выявление различных проявлений школьного насилия по отношению к подросткам; опросник А.Г. Самохваловой «Трудности в общении со сверстниками и взрослыми», позволяющий выявлять у подростков коммуникативные трудности четырех групп: базовые, содержательные, инструментальные и рефлексивные [13]. Статистическая обработка данных проводилась с помощью программного пакета SPSS Statistics V.19.0 (U-критерий Манна-Уитни, контент-анализ свободных высказываний подростков, множественный функциональный критерий $\varphi^{*}$-угловое преобразование Фишера, корреляционный анализ Спирмена).

Результаты исследования показали, что примерно равное количество российских $(57,4$ \% выборки, $\mathrm{n}=89: 37$ девочек и 52 мальчика) и украинских подростков (52,9 \% выборки, $\mathrm{n}=82$ : 44 девочки и 38 мальчиков) чувствуют себя жертвами школьного насилия. Однако формы этого насилия имеют социокультурную специфику $(\mathrm{p} \leq 0,005)$. Так в образовательной среде российских школ преобладает непосредственное насилие - буллинг со стороны сверстников или старшеклассников, моббинг со стороны учителей; а луганские подростки чаще становятся жертвами скрытой, опосредованной травли, осуществляющейся с помощью современных средств коммуникации (кибербуллинг, троллинг). Установлено, что жертвы школьного насилия значимо чаще испытывают дискомфорт, негативные субъективные переживания в ситуациях общения $(\mathrm{p} \leq 0,001)$; у них значимо чаще возникают базовые $(\mathrm{p} \leq$ $0,004)$, содержательные ( $p \leq 0,03)$ и инструментальные $(\mathrm{p} \leq 0,007)$ коммуникативные трудности. Рефлексивные трудности чаще проявляются у подростков, которые чувствуют себя безопасно в образовательной среде $(\mathrm{p} \leq 0,02)$. Следовательно, жертвы школьной травли более сконцентрированы на самонаблюдении и самоанализе (иногда склонны к чрезмерному самоконтролю, блокирующему спонтанные коммуникативные проявления), готовы признавать и исправлять свои ошибки в общении (в некоторых случаях могут винить себя за ошибки других, признаваться в том, чего не совершали).

Буллинг со стороны сверстников или старшеклассников, который чаще встречается в российских школах, - это длительное физическое или психологическое насилие в отношении подростка, не способного себя защитить, со стороны группы сверстников или отдельной личности [8]. Буллинг проявляется как в физической (побои, порча вещей), так и в психологической форме (оскорбления, угрозы, насмешки, негативные оценки жертвы, ее деятельности, бойкот, отказ в доверии). Установлены значимые взаимосвязи данной формы школьного насилия с такими коммуникативными трудностями подростков, как замкнутость, нежелание идти на контакт, враждебное восприятие партнера, боязнь проявлять инициативу, креативность в общении, малоэмоциональность, бедность и недифференциорованность невербальных проявлений, склонность к конформизму, подчинению, шаблонность, стереотипность коммуникативного поведения $(\mathrm{p} \leq 0,01)$.

Моббинг со стороны педагогов - это форма психологического насилия учителей по отношению к подросткам, к которым они испытывают негативные чувства, проявляющаяся в постоянных придирках, негативных, резких оценках личности ученика, прилюдном высмеивании его недостатков, ошибок. В образовательном пространстве российских школ педагоги реализуют вертикальный вид моббинга («боссинг»), поскольку пользуются своей властью, требуют подчинения, применяют различные санкции к подросткам за непослушание, проступки, нежелательное поведение, неудовлетворительных внешний вид. В 
результате подростки-жертвы моббинга всячески избегают общения с учителямиагрессорами и стремятся «понравиться» другим педагогам любыми способами (нередко манипулятивными и нечестными); испытывают гелотофобию и страх публичного выступления на уроках этих педагогов; трудности сотрудничества со сверстниками; они индивидуалистичны, чрезмерно тревожны, болезненно воспринимают критику, но вместе с тем сами склонны к проявлению вербальной агрессии по отношению к одноклассникам, не готовы признать свои ошибки $(\mathrm{p} \leq 0,03)$.

Моббинг в образовательном пространстве школ Луганска также присутствует, но имеет другие основания. Его причина - национальная вражда и неприязнь. Так, педагоги украинской национальности подавляют детей русского происхождения, называют их «чужаками», «захватчиками», «неверными» и др.; а русские учителя довольно часто проявляют негативные эмоции, унижают, занижают оценки украинским детям. По сути дела, школьный класс становится моделью социальной ситуации гражданской войны, которая длится в Луганске уже несколько лет. Подобный вид моббинга вызывает у подростков такие коммуникативные трудности, как эгоцентризм, основанный на этноцентризме; ожидание предвзятости и негативного отношения со стороны учителей; трудности ориентации в коммуникативной ситуации (подростки не знают, чего можно ожидать от педагогов); фонетические и экстралингвистические трудности, возникающие в стрессовой ситуации межпоколенного взаимодействия; трудности принятия ведущей позиции в общении; трудности оценки последствий собственных коммуникативных действий $(p \leq 0,006)$. Вместе с тем, подростки не стремятся к полному разрыву отношений с педагогами-агрессорами; напротив, стараются им угодить, понравится, вызвать у них положительные эмоции, испытывают повышенную эмоционально-личностную зависимость от их мнения и действий, минимизируя тем самым для себя стрессогенность социальной ситуации, сложившейся в школе.

Кибербуллинг - это «виртуальный террор», анонимные, намеренные оскорбления, угрозы, диффамации и сообщение другим компрометирующих данных с помощью современных средств коммуникации, как правило, в течение продолжительного периода времени [6]. Кибербуллинг осуществляется подростками в информационном пространстве, например, через электронную почту в Интернете, с помощью программ для мгновенного обмена сообщениями в социальных сетях, группах, размещения на видеопорталах непристойных видеоматериалов, посредством мобильного телефона (SMS-сообщений или надоедливых звонков). Жертвами кибербуллинга значимо чаще становятся луганские подростки, в связи с чем у них возникают в общении такие трудности, как чрезмерная тревожность, раздражительность, склонность к косвенной агрессии, подозрительность, недоверчивость; они тщательно планируют и чрезмерно контролируют коммуникативные действия, предпочитая стереотипные, шаблонные лингвистические средства, проявляя бедность невербального поведения; избегают близких контактов, ожидают предвзятого отношения к себе, испытывают рефлексивные трудности; постоянно контролируют переписку в телефоне и социальных сетях $(\mathrm{p} \leq 0,01)$.

Троллинг - процесс анонимного размещения на виртуальных коммуникативных ресурсах (на форумах, в дискуссионных группах, блогах и др.) провокационных сообщений с целью нагнетания конфликтной обстановки путем нарушения правил этического кодекса интернетвзаимодействия [4] - также более характерен для образовательной среды луганских школ. Распространение ложной информации, клевета, оговоры, сплетни в социальных сетях (причем не только в адрес подростков, но и в адрес их родных и близких) чрезвычайно болезненно воспринимаются детьми, вызывая волну ответной агрессии, что отражается не только в интернет-коммуникациях, но и в ситуациях реального общения. Жертвам троллинга свойственны чувство безысходности, невозможности повлиять на ситуацию; проявляется враждебность, завистливость по отношению к популярным в группе сверстникам; возникают трудности эмпатии, взаимопонимания, доверия, подозрительность в межличностных контактах (особенно в случаях, когда тролль анонимен); снижается 
коммуникативная активность, адекватность и креативность; возникают трудности самоконтроля в общении, планирования и перестройки коммуникативной программы, трудности обратной связи $(\mathrm{p} \leq 0,03)$.

Обобщая результаты исследования, можно сделать следующие вывводы:

1. Одним из важнейших механизмов социализации и индивидуализации ребенка, развитие его субъектных свойств и коммуникативных компетенций является образовательная среда. Проявление различных форм насилия в образовательной среде нарушает психологическую безопасность ребенка, становится значимым фактором риска социальной дезадаптации, затрудненного общения, аддиктивного поведения субъекта.

2. Социокультурная среда детского онтогенеза, характеризующаяся межнациональным конфликтом, непрекращающимися военными действиями, социальной депривацией, фрустрацией базовых потребностей личности, деформацией ценностно-смысловой сферы ребенка, является мощным фактором риска возникновения анонимных, опосредованных форм школьного насилия (кибербуллинг, троллинг) и специфических коммуникативных трудностей у подростков.

3. Существуют кросс-культурные различия форм школьного насилия, направленных на подростков, воспитывающихся в мирных условиях и в условиях военных действий. Каждая форма насилия связана с возникновением у подростков специфических коммуникативных трудностей. Однако можно выделить трудности общения, свойственные всем жертвам школьной травли, - замкнутость, подозрительность, защитная агрессивность, трудности установления контакта и сотрудничества, трудности планирования и перестройки коммуникативных программ, страх самовыражения в ситуации общения, эмоциональная скованность, чрезмерный самоконтроль, склонность к конформизму, безынициативность, рефлексивные трудности.

\section{Литература}

1. Александровский Ю.А., Лобастов О.С., Спивак Л.И., Щукин Б.П. Психогении в экстремальных ситуациях. - М., 1991. - 115 с.

2. Баева И.А., Якиманская И.С. Мониторинг психологической безопасности образовательной среды и качества образования в условиях модернизации [Электронный pecypc] // Психологическая наука и образование psyedu.ru. 2013. № 1 .

3. Василюк Ф.Е. Психология переживания. - М.: МГУ, 1084. - 200 с.

4. Внебрачных Р.А. Троллинг как форма социальной агрессии в виртуальных сообществах // Вестник Удмуртского университета. Философия. Социология. Психология. Педагогика. - 2012. - № 1. - С. 48-51.

5. Гаспарян Х.В. Возрастно-психологические особенности переживания трудных жизненных событий (на примере армянских детей и подростков, переживших землетрясение и военные действия): Дис. ... канд. психол. наук. - М., 2005. - 181 с.

6. Ениколопов С.Н. Экологическая модель исследования насилия // Материалы 6-ой Российской конференции по экологической психологии. - М.: ПИ РАО, 2012. - С. 136-138.

7. Еремина Л.Ю. Система социально-психологической работы с детьми, переживающими последствия чрезвычайных ситуаций [Электронный ресурс] // Системная психология и социология. - 2011. - № 4.

8. Лейн Д.А. Школьная травля (буллинг) // Детская и подростковая психотерапия / ред. Д. Лейн, Э. Миллер.- СПб.: Питер, 2001. - С. 240-274.

9. Самохвалова А.Г. Коммуникативные трудности подростков и способы совладания с ними в условиях социальной депривации [Электронный ресурс] // Психологические исследования. - 2016. - Т. 9. - № 49 - С. 5.

10. Самохвалова А.Г. Коммуникативные трудности ребенка: феноменология, факторы возникновения, динамика. - Кострома: КГУ им. Н.А. Некрасова, 2014. - 342 с.

11. Самохвалова А.Г. Социальное сиротство как фактор затрудненного общения подростка // Вопросы психологии. - 2016 - № 3. - С. 29-40. 
12. Самохвалова А.Г. Социокультурная детерминация коммуникативных трудностей современных детей и подростков [Электронный ресурс] // Психологические исследования. 2017. - Т. 10. - № 55. - С. 5.

13. Самохвалова А.Г. Ступени самовоспитания личности: учебно-методическое пособие. Кострома, КГУ, 2017. - 178 с.

14. Тарабрина Н.В. Практикум по психологии посттравматического стресса. - СПб.: Питер, 2001. - 272 с.

Cyxux C.A.

\section{ОПЫТ ЛИНГВОПСИХОЛОГИЧЕСКОГО ПОДХОДА В ПРАКТИКЕ СУДЕБНЫХ ЭКСПЕРТИЗ}

Современная наука опирается на три базовых эпистемологических ценностей. Одна из ценностей являлась доминирующей еще с античных времен и ориентировала исследователей на постижение и описание сущности мироздания. Другая ценность лежит в основе использующего подхода и задает критерии истинности с точки зрения утилитарной пользы. Она является доминирующей в современной научной парадигме - основа «сайентизма». Это можно свести к сентенции «что в практике полезно, то и истинно». Третья ценность научного поиска связана с гуманистической ценностью, предполагающая понимающий подход, где субъективность признается релевантной и обладающей статусом объективности. При этом истинность определяется сквозь призму ценности бытия. Ценностная парадигма задает принципы, соответствующие синергетике как науке по описанию динамичности событий и явлений. Она задает рамки вероятностного описания, которые составляют методологическую основу квантово-релевантностной парадигмы.

Однако точка зрения утилитарно-прагматического подхода в лингвистике позволяет решать прикладные задачи, например, установление авторской принадлежности текстов, составление тезаурусов для информационно-поисковых систем, построение речевых стратегий при проведение предвыборных компаний, a также конструирование символических средств, с целью манипулирования или управлении массовым сознанием. Важные прикладные задачи решаются, в том числе и в юридической сфере. Это лингвистическая и психолингвистическая экспертизы. Задачи в судебной экспертизы формулируются в виде вопросов: типа «имеются ли в представленных материалах(протоколах, фонограммах) резкая негативную оценку или враждебные отношение к не отдельным представителям, а ко всей этнической группе или имеются ли высказывания содержащие пропаганду неполноценности граждан какой-либо национальности; а также содержит ли текст выказывания со значением скрытого или явного воздействия на психику субъекта или находится ли субъект в состоянии, влияющем на адекватность восприятия высказываний в его адрес; содержит ли текст высказывания, выражающие оскорбление личности или унижающие честь и достоинство гражданина». Ответы на эти вопросы требуют процедур объективации или верификации. Как известно, каждая феноменология или теоретическая модель требует свою операционализацию или исследовательские процедуры. Так структурно-системное языкознание имеет свой набор исследовательских операций и процедур, а прагмалингвистическое - свой. Психолингвистическое понимание предполагает также свой алгоритм описания.

Несмотря на различные углы рассмотрения лингвистических конструкций, прикладная сфера предполагает использование единицы описания в зависимости от задач судебной экспертизы. В качестве методов исследования могут выступать операции по работе с содержательными единицами: интерпретация значения предложений через элементарные пропозиции. Известно, что значение предложение может конструироваться за счет такого явления как контаминация. Предложения, имея простую тектоническую структуру, могут 
иметь сложную семантику, т.е. когда одна семантическая позиция может совмещать или выполнять в одной синтаксической позиции несколько содержательных функций. При этом семантическое осложнение может достигаться также и через вторичную предикацию, получающую формальную репрезентацию с помощью деепричастных, причастных оборотов, выступающих в атрибутивных синтаксических функциях. Такие вербальные построения могут указывать на активность левого полушария и достаточный контроль сознания, особенно, при определении психоэмоционального состояния субъекта речевой деятельности. Эмоциональный синтаксис, как известно, имеет дело с элементарными конструкциями(первичными предикациями) и номинативными предложениями, пропозиции которых не имеют грамматической актуализации, т.е. значение времени не выражено грамматическими средствами или выражено нулем. Номинализации или номинативные комплексы имеют сопряжение с фиксацией сознания на некоторых идеях, т.е. сознание характеризуется ригидностью, главным признаком которого является значение статичности в языковых конструкциях. Значение же динамичности имеет грамматическую репрезентацию через значения времени, выраженное сказуемым (актуализованный предикат). Эмоциональное состояние коммуниканта может также сигнализироваться употреблением слов-паразитов, инверсированных фраз и незавершенность [1]. Индекс Шлисмана, т.е. возрастание употребления глаголов по сравнению с существительными также может служить указателем уравновешенного психоэмоционального состояния. Ведь глагол как форма выражения предиката наименее устойчив к стрессу. Частотность употребления частей речи может отражать некоторые стратегии адаптивного поведения.

При эмоциональных помехах происходит сдвиг от левополушарной активности к правой, которая определяет преобладание клишированных форм выражения, конкретности лексических значений, образности, неологичности при вербальном конструировании. Если левое полушарие отвечает за образование речевых паттернов, то правое - за их механистичность выполнения. Депрессивность также может иметь лингвистические индексы - возрастание указательно-заместительных частей речи, служебной лексики, наречий, частиц. Повторяемость некоторых слов, как и повторяемость, вообще, в том числе эхолаличность, есть вербализация как способ уменьшения состояния неопределенности. Ведь состояние неопределенности является одним из атрибутов тревожного и депрессивного психоэмоционального состояний.

Активность и пассивность залога также может сопрягаться с некоторыми психологическими переменными. Осознание себя как активного субъекта предполагает идентификацию говорящего с активным залогом. Опускание семантического субъекта связано с различными психологическими причинами. К таковым можно отнести желание коммуниканта снять с себя ответственность за то, что утверждается в высказывании. Другой причиной может являться экстернальность субъекта, т.е. склонность его к описанию мира сквозь призму внешних причин и личной безответственности, а также инфантильности сознания.

В качестве формального маркера может выступать длина предложения. Установлено, что к построению длинных предложений склонны интровертированные личности, тогда как экстраверты оказываются более разнообразными в использовании лексики, а также в большей степени опираются на существительные с использованием большего количества предложений для выражения замысла речи, чем интроверты. Интроверты склонны к употреблению местоимений и наречий. Их речь отличает большая предикативность (главное свойство внутренней речи), так как ориентирована на себя, чем на других в силу аутичности личности. Для экстравертировнной психики свойственно описание мира сквозь лексику со значением конкретных качеств предметов окружающего мира, более дробное или дифференцированное описание ситуаций, как и более абстрактное описание характерно для шизоидной психики.

Структурно- системное языкознание позволяет акцентировать внимание на единицах как формально-тектонического, так и контенсивного уровней. Употребление лексики с 
абстрактным и конкретным значением также имеет приоритет у различных типов психики. Чем шире сфера референции языкового знака, тем более значение размыто в сознании субъекта. Синтаксическая связь также может отражать некоторые психологические признаки. Так паратаксическая связь отражает ассоциативность мышления, т.е. связывать явления, не дифференцируя отношений между ними. Гипертаксис же в тексте отражает сложность семантического пространства субъекта, благодаря которому субъектом осуществляется возможность классификации предметов и явлений по критериям, имеющим разные основания. Тема-рематическое членение входит в инструментарий структурного языкознания. Доминирование тематической прогрессии в языковом сознании указывает на психическое состояние субъекта. Тенденция полиремного изложения наблюдается, когда одной теме приписывается много разных рем, что характерно для обсессивного или навязчивого состояния сознания. Застревание на одной теме также может быть свойственно ригидному сознанию. Однако в реальном повествовании присутствуют все три разновидности тема-рематических прогрессий (линейная, со сквозной темой и общей). Исследователь же может лишь отметить тенденцию или склонность субъекта в способе развертывания информации в дискурсе. Она зависит от особенности текучести сознания и активности энергии бессознательного. Данный вопрос нуждается в специальном исследовании.

Для прикладных задач в судебной психолингвистической экспертизе могут использоваться методы дискурсивной психологии и коммуникативно-прагматической парадигмы в лингвистики, интересы которых оказываются схожими. Для дискурсивной психологии предметом исследования выступает ментальное состояние субъекта, которое определяется мотивами, интересами, оценками, намерения, т.е. интенциями субъекта. В качестве исследовательской технологии используется интент-анализ для выявления интенций на основании субъективного оценивания слушателем или квалифицированных специалистов. При этом, исходный текст перифразируется с целью выявления того, чем вызвано это высказывание и какова его целевая направленность.

Эксперт может использовать метод Готшалька-Глезера по диагностике осознанных и неосознанных аффектов в содержании устной и письменной речи человека. При этом показателем аффекта выступают частота появлений определенных категорий, степень интенсивности и степень личного участия в эмоционально значимых состояниях. При этом вытесненные аффекты устанавливаются через фиксацию защитных механизмов, проявляющихся через приписывание его другим людям, животным или неодушевленным объектам, а также аффект отрицается или не признается. Величина аффекта увязывается с частотой употребления определенных категорий. Однако теоретические положения позволяют сомневаться в валидности данной процедуры, на что указывалось многими исследователями.

Прагмалингвистическая парадигма в лингвистике открывает новые возможности для феноменологии. В качестве таких единиц выделяется новый набор таксономий. К примеру, это типы речевых действий, когнитивная организация темы коммуникации, типы отношений между партнерами. Для исследования воздействия текстов СМИ на массовое сознание может адаптироваться контурный анализ направленности лингвистических структур определенные уровни психической организации реципиента, опыт адаптации,[2]. Комплементарный принцип проведения экспертизы предполагает пропорциональное сочетание взаимодополняющих процедур при анализе продуктов коммуникации. Особенности лингвопсихологических процедур в судебной экспертизе см. [3].

Примерная схема проведения экспертного изложения результатов исследования может быть представлена следующим образом. Объектом может выступать стенограмма разговора между М-1, М-2, М-3, М-4. Предметом исследования может являться интенциональная и содержательная составляющие разговора (дискурса). Соответственно цель исследования может заключаться в установлении скрытого и ли явного воздействия на коммуниканта М-2, которое может гипотетически восприниматься как психологическое насилие над М-2 и его 
эмоционально-психическое состояние, влияющее на адекватность его восприятия речевых реплик участников диалога. Для достижения поставленной цели необходимо решение ряда задач: 1) выявить интенционально-прагматическую составляющую разговоров (дискурсов); 2) установить содержательную (семантическую) структуру дискурсов; 3) определить степень активности и социальных отношений партнеров по общению. В качестве методов исследования могут привлекаться метод, интерпретаций значений предложений через набор элементарных пропозиций, пресуппозиционный анализ, мотивационный или интент-анализ, анализ операциональных кодов, когнитивное картирование.

Дискурс участников М-1, М-2, М-3, M-4 представляет собой речевое взаимодействие, состоящее из 658 речевых действий участников, из которых 457 речевых действий текстуально фиксированы, т.е. 69\% дискурса имеют как содержательную, так и интенциональную формальные репрезентации. Речевая активность преобладает у М-3 и М-4.

Содержательную основу составляет когнитивную структуру (скрипт допроса), реализуемого в пропозициях со значениями «получения денег за работу» и нарушения обязательств по выполнению оплачиваемой работы.

Интенциональная структура представлена речевой стратегией со стороны коммуникантов M-2 и М-3 речевыми действиями обвинения в невыполнении M-2 предписуемых действий. Косвенно М-3 и М-4 аргументируют свое отрицательное эмоциональное отношение к М-2. Главная интенция М-2 «отрицания» причастности М-1 к нарушению взятых обязательств по выполнению работ и «забывания» отдельных фактов и событий, что может свидетельствовать о защитном типе речевого поведения, т.е. о выполнении спланированного предварительно поведения на допросе М-2. М-3 проявляет вербальную агрессию, совершая речевые действия угрозы «тебя запечатают», добиваясь косвенно признания вины. Так высказывание «мы оформляем явку с повинной» в пресуппозиции, т.е. невыраженном знании содержится информации виновности. Однако речевые действия угрозы зачастую имеют форму психологической разрядки и демонстрации социального превосходства М-3 и M-4. на это указывает употребление нецензурной лексики, с помощью которой утилизируется эмоциональный заряд коммуникантов. М-2 в силу своей повышенной тревожности (употребление M-2 местоименных наречий и частые повторы одного того же) воспринимает действия М-3 как угрозу, о чем также свидетельствует телеграфный стиль изложения. М-2 избегает отвечать на вопросы М-3. что указывает на имплицитную, т.е. скрытую конфликтность, которая проявляется через коллокутивные акты: отбрасывания, умолчания. При этом М-2 не замечает логического противоречия, когда говорит, что денег он от M-1 я не получал» и тут же утверждает, что M-1 его не кидал, хотя факт получения денег M-1 установлен. Это провоцирует на боле повышенную эмоциональность в высказываниях в М-3 и М-4. В суждениях типа «в тюрьму хочешь», используются не в качестве агрессии, а как аргумент в убеждении М-2 действовать согласно логике М-3 и М-4. Однако М-2 пытается противодействовать, добиваясь смягчения отношения к себе, указывая на родственные отношения с капитаном милиции и утверждая свою непричастность к предъявляемым обвинениям, а также сохранить отношения с М-1, с которым была предварительная договоренность.

Речевая стратегия М-3 и М-4 включает типы речевых действий: упрека, вопросов, констатации, директивных, подчиненных главной макроинтенции в получении подтверждения от M-2 письменного признания. Они направляют фокус внимания М-2 в описании мотивов поведения М-1, что должно способствовать завершению следствия. Итак, на основании анализа речевого дискурса участников коммуникации можно сделать выводы, которые позволяют ответить на вопросы, поставленные в назначенной лингвистикосмысловой судебной экспертизе. Во-первых, в тексте нет высказываний, которые могут восприниматься как психологическое насилие над субъектом по содержанию, но по форме речевые действия содержат негативный эмоциональный заряд, который свидетельствует о конфликтном психоэмоциональном состоянии М-3 и М-4, возникшим из-за несоответствии поведения М-2. их ожиданиям, заданными потребностью завершения расследования. Это 
проявляется в форме их высказываний, где выражается вербальная агрессия в использовании нецензурного языка и вопросов типа « в тюрьму хочешь?» цель которых является создания эмоционального состояния неопределенности и как следствия тревожности. Преодолеть это состояние возможно, если М-2 выполнит намерения М-3 и М-4, которые направлены на решение их функциональной задачи. Высказывание «щас аппарат подключим» не содержит угрозы в контексте диалога, так как может предполагать многое и непонятное для М-2, то ли это полиграф, то ли это нечто, что должно повысить уровня тревожности М-2, так как сложность для М-2 в категориальной отнесенности значения «аппарат» вызывает состояние неопределенности. В данном случае речь идет скорее о манипулятивном приеме, который осуществляют M-3 и M-4, чем о реальной угрозе. Речевое поведение М-3 и М-4 имеет явно демонстративный характер, подчеркивающий их социальный статус, с одной стороны, а с другой- выражение их внутренний конфликта. Использование нецензурного языка при этом выступает средством разрядки аффективного эмоционального состояния. Конечно, намерения M-3 и M-4 направлена на решение их функциональной задачи, а не на действия, которые они демонстрируют в интересах М-2, как это и представлено в эксплицитной форме высказываний.

Субъект М-2 находился в состоянии повышенной тревожности, что оказало влияние на восприятие высказываний в своей адрес. Состояние тревожности и внутренней конфликтностью обусловлены расщепленностью противодействующими потребностями, с одной стороны - признаниями относительно факта событий и с -другой, обязательствами с подозреваемым.

Другой иллюстрацией может служить фонограмма и стенограмма дискурса участников Р. и В., представляющая собой речевое взаимодействие, состоящее из 307 речевых действий участников, распределенных пропорционально. В совершила на 9 действий больше. Однако скорее это свидетельствует о тревожности и экстравертивности психики В. Когнитивное картирование позволяют выявить темы разговора, представляющие в виде скриптов (разновидности семантических сетей). Скрипт: «взятие кредита» при этом акцентируется терминалы скрипта или подтемы - «погашение кредита и гарантийный залог». В фокусе внимания В и Р терминалы или подтемы: «уточнение личности судебного пристава», «непогашенный долг», «залог». Интерес участников диалога к подтеме залога обусловлен причастностью $\mathrm{P}$ к гарантии безопасности В в погашении кредита, а также процедурой разрешения отношения с заемщика В с банком, ее документальное обеспечение. В дискурсе тематизируется проблема имущественной гарантии заемщика $\mathrm{B}$, в оформлении которой $\mathrm{P}$ оказывал В помощь, за что был вознагражден В. Однако Р подводит вознаграждение под категорию спонсорского взноса с целью акцентирования в сознании В идеи добровольности, а не намеренного получения денег. Эта тема получает развитие через аргументацию Р своей непричастности в получении денег, а простым участием в системе передачи денег, а не их присвоении. Тема возврата кредита представлена $\mathrm{P}$ через ссылку на информацию о некорректности поведения банка к по отношению к заемщикам, имплицитно или скрыто содержащая информацию об оправдании поведения участников разговора В. и Р. Вся тематическая составляющая дискурса начинается с терминала о судебном приставе скрипта получение кредита и заканчивается этим же терминалом, когда Р побуждает В получить информацию о этом приставе. Дополнительная тема в дискурсе у В представлена в вербализации эмочионального состояния. Оно сигнализируется оценочной лексикой, местоименными наречиями как индикаторами состояния тревоги.

есмотря на то, что Р. менее активен в речевой активности, он психологический обладает большей властью (информационная форма власти). Анализ прагматической составляющей дискурса позволяет выявить цели и интенции участников. а также гиперинтенции (доминирующие). На основе типов речевых действий (иллокуций) выявляется доминирующая интенции В и Р. У В доминируют две интенции:- упрек Р за невыполненные обязательства - запрос информации у Р о последствиях для В. При этом В формально доминирует, на что указывает большая речевая активность, но содержательно Р является 
ведущим в разговоре. В по ходу коммуникации совершает речевые действия: обвиняет, высказывает опасения по поводу последствий, обосновывает опасения, угрожает, упрекает Р.

Доминирующие интенции Р: отвести от себя подозрения и опасения со стороны В, оправдать себя, успокоить В. При этом Р совершает действия: констатации, обещания, отклонение угрозы В, высказывания подозрения о причастности В к следственным органам, согласия, побуждения В к получению информации, предложение для В форм поведения при встрече со следственными органами, предложения правдоподобных фактов, снимающих подозрение с Р и формирующую легенду о невинности В, инструктирует В. При этом усилия Р направлены на координацию действий Р и В. Р отдает поручения и побуждает В к сбору информации. $\mathrm{P}$ проявляет скрытность. $\mathrm{C}$ помощью интонации $\mathrm{P}$ пытается создать впечатление о безобидности и незначительности ситуации. В дискурсе № 2 содержится 288 речевых вкладов В и Р. Р совершает 145 речевых действий, В -143.

1. Основными темами диалога являются: 1) документальное оправдание отсутствие залогового имущества у В (квартиры, мебели, автомобиля, бытовой техники). 2) передача денег от В к Р. 3) взаимное гарантирование безопасности обоих участников диалога через составление взаимных письменных расписок 4) поведение В при проведение дознания 5) подбор правдоподобных аргументов для оправдания поведения Р. и одновременно конструирование модели поведения В в процессе разбирательства следственных органов. 6) ведение дознания по уголовному делу относительно Р.

2. Прагматическая составляющая дискурса представляет систему целей речевого взаимодействия, формализуемое в виде речевых стратегий. Р строит речевую стратегию, главной интенцией которой является выработка общей стратегии поведения в связи непогашенным кредитом В и минизации подозрения к причастности Р к этому процессу. Р совершает действия: уточняет, высказывает опасения, успокаивает В, оправдывает свое поведение, обещает, предлагает, угрожает, соглашается, упрекает, побуждает В не приходить в прокуратору, а также побуждает В собрать информацию о Р. В совершает речевые действия: экспрессивные (описания своего состояния тревоги и возмущения), упрекает Р, угрожает, высказывает недоверие, побуждает $\mathrm{P}$ найти выход, оправдывает себя. Эти действия подчинены одной главной цели запрос информации о своем поведении в сложившейся ситуации. Со стороны $\mathrm{P}$ совершаются речевые действия побуждения В не соглашаться с мнением пристава по оценке имущества; написать бумагу о том. что В претензий к Р не имеет, а обращение в правоохранительные органы считать ложным доносом, побуждает В принять версию интерпретации Р о продаже машины, а также не нарушения сроков запроса Р относительно должника В, что должна сказать В относительно потенциальных вопросов дознавателей относительно Р. Со стороны В имеются побуждение к Р достать гарантийные талоны на вещи, выписанные не на В, а также написать бумажку-гарантию о том, что у В не будет проблем с разбирательствами по кредиту. В побуждает Р придумать оправдывающие аргументы. Р имеет психологическую власть над Р как по формальному, так и по информационному критериям. Р генерирует возможные модели поведения в будущем общении с официальными органами как для В, так для Р. При этом Р косвенно отрицает факт получения денег от В через вопрос, которые звучит с интонацией удивления. Оба партнера В и Р испытывают психоэмоциональное состояние тревоги. На это указывают как лексические, так и грамматические индикаторы, преимущественно у В через повторы типа: «Факт, что ты знал, что у меня «фокус». Ты знал, что у меня «фокус»» частое использование местоимений и местоименных наречий как индикатор импрессивной речи т. е. речи для себя. позволяющей снять состояние неопределенности - источника тревожности. Так тревожность $\mathrm{P}$ сигнализируется местоименными наречиями (Р: «ну там же, потому что у меня нет возможности выехать ...» Об эмоциональном волнении свидетельствует нарушение синтаксических конструкций, хотя предикат наиболее устойчивая к стрессу единица. К примеру, В: «А, чтоб вот этот вот...» или помещает описание в логику возможных миров Р: ... знаешь это в том случае, когда реально там знаешь допустим, ну и то это такая редкость...». Таким образом, современное 
состояние лингвопсихологического знания открывает вероятностные характеристики описания психического состояния субъектов речевой деятельности при решении задач, поставленных перед экспертом, по вявлению корреляций языкового кода( процесс опредмечивания) с психоэнергетическим состоянием субъекта знаковой активности. Для построения более широких вероятностных связей между психологическими и лингвистическими переменными необходимы масштабные эмпирические исследования по выявлению корреляций. Психологическая диспозиция личностных качеств оказывает влияние на знаковое конструирование. Однако это может выступать как гипотеза для будущих научных верификаций.

\section{Литература}

1. Спивак Д.Л. Измененные состояния сознания.- СПб. Ювента. 2000.-296 с..

2. Сухих С.А., Калашава А. Ш. Лингвопсихологический анализ скрытого воздействия в дискурсе/Психолингвистические аспекты изучения речевой деятельности./Урал. Гос. пед. ун-т.- Екатеринбург, 2004. вып.2.- с.205-216.

3. Сухих С.А.Коммуникативная компетентность личности в общении. Краснодар. 2016.

Теплякова А.П., Макаревская Ю.Э.

\section{ПРОБЛЕМА БЕЗОПАСНОСТИ РЕБЁНКА В ЭКСПЕРТНО-ПСИХОЛОГИЧЕСКИХ ИССЛЕДОВАНИЯХ ИНТЕРЕСОВ ДЕТЕЙ}

В законодательстве РФ нет определения термина «интерес ребенка» хотя указанный термин зачастую упоминается в нормативных актах. На практике это является проблемой в юриспруденции, так как нет четко регламентированного понятия, что же такое интересы ребёнка и что это понятие включает в себя. А для психологии это проблема наполнения этого содержания в диагностике, а так же в проведении психологического исследования, что непосредственно включает в себя интересы ребёнка.

Что же такое интересы ребёнка? Подход учёных к содержанию рассматриваемого понятия в целом един. Ю.Ф.Беспалов [1] видит интересы ребёнка в создании условий, необходимых для его содержания, благополучного развития. Именно термин «развитие» составляет основу определения понятия «интересы ребёнка». Оценка интересов ребёнка с точки зрения его развития (нравственного, духовного, физического) служит первым шагом в определении его истинных интересов как развивающейся личности.

Обращает на себя внимание авторская концепция интересов ребёнка, представленная О.И.Шолгиной в ее диссертационном исследовании [2]. В данной концепции, под интересами ребёнка следует понимать оптимальные и объективно обоснованные условия проживания, содержания и воспитания ребёнка, обеспечивающие его физическое, психическое, нравственное и духовное развитие.

С психологической точки зрения под интересами ребенка, в этой статье, мы рассматриваем: периодизацию психического развития, новообразование возраста, ведущий вид деятельности. Таким образом, мы, как психологи, можем написать в экспертном заключении, кто из родителей лучше и больше соблюдает интересы ребенка, и соблюдает ли их вовсе. Этим самым мы можем обеспечить безопасность ребенка, неважно с кем из родителей он останется, главное чтобы его интересы были соблюдены с психологической точки зрения. Говоря непосредственно об экспертной деятельности, то чаще всего этот вопрос возникает именно в высоко конфликтных разводах, когда соблюдение интересов является гарантией безопасности самого ребенка. Следует подчеркнуть, что у родителей в законе прописано, что они должны обеспечивать интересы своего ребёнка (СК РФ Статья 65. Осуществление родительских прав).

Одним из основных факторов безопасного развития ребёнка это семья. Ячейка общества, которая порождает единство интересов, задач, стандартов и взаимопонимание, или же 
основывается на них. Наиболее заметным явлением, характеризующим нарушения единства семьи, являются разводы. Особенно при разводе страдают дети, для которых он потенциальный фактор десоциализации, источник многочисленных проблем. Рост числа расторгнутых браков растёт, а значит, и детей в разведенных семьях. Исходя из ситуации выше, можно сказать, что тема данного исследования будет актуальной. Так же говоря об актуальности проблемы, стоит отметить статистику России, которая говорит нам о том, на тысячу браков приходится 700 разводов, следовательно, в это число входит и высоко конфликтные разводы супругов, которые напрямую сказываются на ребёнке.

Для примера рассмотрим возраст до 10 лет, поскольку в этом возрасте ребёнок не может высказать своего аргументированного мнения о том, с кем ему оставаться.

Под влиянием обучения и воспитания, психическое развитие ребенка протекает по определенным стадиям (этапам), соответствующим определенному возрастному периоду и задачей психолога в экспертном исследовании понять реализованы ли возможности ребенка в должной степени.

Первой из задач психолога является определения уровня психического развития, в том числе интеллекта. Говоря о задачах психолога, стоит так же отметить, что соответственно мы смотрим, нет ли у ребенка умственной отсталости, если нет умственной отсталости, но есть отставание в психическом развитии, то у нас есть уже момент, над которым нужно задуматься, так как возможна педагогическая запущенность. Соответственно, исходя их вышесказанного, мы можем говорить о том, насколько реализованы возможности ребёнка в плане психического развития. Далее мы рассмотрим эмоциональную сферу, следовательно, в каком состоянии находится ребенок, прибывая в условиях высоко конфликтного развода своих родителей. Говоря о состоянии, мы имеем в виду, присутствуют ли у него выраженные страхи, рассматриваем уровень тревожности, а так же наблюдаем общий фон благополучия эмоциональной составляющей ребёнка. По личностным особенностям мы будем говорить, только если идёт конкретизация вопросов по привязанности к одной из сторон родителя, с кем ребенку будет наиболее благополучно.

Таким образом, обосновывать интересы ребёнка предлагаем исходя из его возрастного периода, так как каждый возрастной период психика должна решать определённые задачи и по итогам решения этих задач мы говорим о том благополучно ли завершается период или нет. Так, к примеру, основываясь на периодизации психического развития Д.Б.Эльконина, в период младшего школьного возраста 7-10 лет, основными задачами психики, ее компонентами, является:

- увеличение словарного запаса до 7 тыс. слов у ребенка. При научении легко овладевает звуковым анализом слов. Ребенок прислушивается к звучанию слова. Потребность в общении младших школьников определяет развитие речи. Контекстная речь - показатель уровня развития ребенка. В письменной речи различают правильность орфографическую (правильное написание слов), грамматическую (построение предложений, образования морфологических форм) и пунктуационную (расстановка знаков препинания).

- мышление в младшем школьном возрасте становится доминирующей функцией, завершается наметившийся в дошкольном возрасте переход от наглядно-образного к словесно-логическому мышлению. К концу младшего школьного возраста проявляются индивидуальные различия в мышлении (теоретики, мыслители, художники).

- память развивается в двух направлениях - произвольности и осмысленности.

В учебной деятельности развиваются все виды памяти: долговременная, кратковременная и оперативная. Развитие памяти связано с необходимостью заучивать учебный материал. Активно формируется произвольное запоминание.

- дети способны концентрировать внимание, но у них еще преобладает непроизвольное внимание. Произвольность познавательных процессов возникает на пике волевого усилия (специального организует себя под воздействием требований). Внимание активизируется, но еще не стабильно. Удержание внимания возможно благодаря волевым усилиям и высокой мотивации. 
- восприятие также характеризуется непроизвольностью, хотя элементы произвольного восприятия встречаются уже в дошкольном возрасте. Восприятие отличается слабой дифференцированностью (путают предметы, их свойства). В младшем школьном возрасте нарастает ориентация на сенсорные эталоны формы, цвета, времени.

- воображение в своем развитии проходит две стадии: на первой - воссоздающее (репродуктивное), на второй - продуктивное. В первом классе воображение опирается на конкретные предметы, но с возрастом на первое место выступает слово, дающее простор фантазии.

В результате учебной деятельности возникают психические новообразования: произвольность психических процессов, рефлексия (личностная, интеллектуальная), внутренний план действий (планирование в уме, умение анализировать).

Исходя из возрастной периодизации, обобщая можно сказать, что младший школьный возраст - период накопления, впитывания знаний, период приобретения знаний по преимуществу. В этом возрасте подражание многим высказываниям и действиям является значимым условием интеллектуального развития. Особая внушаемость, впечатлительность, направленность умственной активности младших школьников на повторение, внутреннее принятие, создание подходящих условий для развития и обогащения психики.

Итак, исходя из предложенного материала выше, можно сделать определенный вывод чтобы обеспечить безопасность ребёнка в ситуации высококонфликтного развода родителей, мы предлагаем на основании определения ведущего вида деятельности, новообразования возраста ребенка, а также возрастной периодизации, рассматривать в понятии интересов ребёнка такие составляющее, как уровень психического развития интеллектуальный и эмоциональное состояние, как базовые необходимые компоненты.

\section{Литература}

1. Беспалов Ю.Ф. Судебная защита прав ребенка. Дис. канд. юрид. наук. Специальность 12.00 .03 - гражданское право; предпринимательское право; семейное право; международное частное право / РПА Минюста РФ. - М., 1997. - 172 с.

2. Шолгина О.И. Интересы ребенка как объект семейно-правового спора. Диссертация на соискание ученой степени кандидата юридических наук - М., 2011

Тучина О.Р., Лялюк А.В.

\section{ПРИМЕНЕНИЕ ПРИНЦИПОВ СУБЪЕКТНО-БЫТИЙНОГО ПОДХОДА ПРИ ИЗУЧЕНИИ РИСКОВ ОБРАЗОВАТЕЛЬНОЙ СРЕДЫ СОВРЕМЕННОГО ВУЗА}

В связи со значительными изменениями сегодняшней жизни важной проблемой современного общества стала проблема психологической безопасности личности и среды, вследствие чего возникла новая область теоретических и эмпирических исследований психология и педагогика безопасности [1;2]. Проблема психологической безопасности рассматривается в двух аспектах: как психолого-педагогическая безопасность личности и психолого-педагогическая безопасность среды. Образовательная система с этих позиций является наиболее значимой сферой, поскольку именно в рамках образовательной среды формируется личность человека, его ценностные ориентиры и особенности бытия в мире.

Психолого-педагогическая безопасность среды рассматривается как «состояние образовательной среды, свободное от проявлений психологического насилия во взаимодействии, способствующее удовлетворению потребностей в личностно доверительном общении, создающее референтную значимость среды и обеспечивающее психическое здоровье включенных в нее участников» [3, с. 111]. Существующие концепции психолого-педагогическая безопасности, выявление основных рисков, способов психологической защиты и совладания, а также выявление и апробация критериев экспертизы психолого-педагогическая безопасности основаны в основном на материале 
исследования образовательной системы школ. Проблема психологической безопасности образовательной системы современного вуза в данный момент представлена рядом эмпирических исследований, которым не хватает методологического обоснования и концептуализации [4].

Нам представляется перспективным для исследования проблем психолого-педагогической безопасности образовательной среды использование субъектного, в частности, субъектнобытийного подхода. Субъектно-бытийный подход к личности акцентирует внимание на способности человека изменять внешнее по законам внутреннего, переустраивать бытие в соответствии со структурой сложившихся личностных смыслов, т.е. так преобразовывать реальность внешнего мира, что он становится следствием объективирования субъективного, продолжением личности. Бытие в данном подходе является не только внешней причиной, обусловливающей становление и функционирование личности, пространства бытия личности непосредственно включаются в ее организацию. Категория «бытийное пространство личности» характеризует многомерность бытия человека, предполагает рассмотрение его как целостности, интегрирующей все аспекты и обусловленной целостностью личности, реализующей личностный смысл в создании и переустройстве бытия. Образовательная среда в данном подходе выступает в качестве объективной предпосылки развития личности и в то же время создается самим индивидом. Соответственно, риски образовательной среды рассматриваются не только как объективный фактор, определяемый особенностями образовательной системы, но и как субъективные представления участников образовательного процесса, которые формируют предпосылки данных рисков. Возникает необходимость эмпирического исследования представлений о рисках образовательной среды субъектов образовательного процесса, преподавателей и учащихся вуза.

Для выявления факторов риска образовательной среды участниками образовательного процесса в вузе респондентов-преподавателей вуза просили перечислить все факторы, негативно сказывающихся на личности студента и мешающих образовательному процессу. В качестве экспертов выступили преподаватели КубГТУ, 32 человека, стаж работы в вузе от 12 до 36 лет. На основании результатов исследования, используя метод контент-анализа, было выделено несколько категорий рисков образовательной среды современного вуза [5; 6].

Затем на основе результатов предыдущего этапа исследования была составлена анкета исследования рисков образовательной среды, в которой респондентов просили оценить по пятибалльной системе, насколько каждый из данных факторов представляет опасность для студентов. В исследовании приняли участие 547 студентов КубГТУ, 257 юношей и 290 девушек от 18 до 25 лет, средний возраст 19,6 лет и 267 преподавателей высшей школы, 106 мужчин и 161 женщина, средний возраст 45,3 года, средний стаж преподавания в вузе 17,5 лет.

Сравнительный анализ оценки факторов риска образовательной среды вуза с позиций преподавателей и студентов при помощи критерия Стьюдента $(\mathrm{p} \leq 0,05)$ показал следующие результаты.

Как показали результаты исследования, студенты в целом значимо выше оценивают большинство рисков образовательной среды вуза, чем преподаватели. Все выделенные в результате контент-анализа виды рисков студенты оценивают как средние и высокие, что говорит о наличии проблемы психолого-педагогической безопасности вузовской среды. Однако влияние большинства внешних рисков образовательной системы, обусловленных действием средовых факторов (социальными, политическими, идеологическими, экономическим факторами, воздействием СМИ) преподаватели оценивают значимо выше, чем студенты. К таким рискам относятся зависимость от соцсетей, негативное влияние радикальных «сайтов ненависти» в сети Интернет; влияние экстремисткой идеологии; утрата культурных традиций и привычных социальных норм (в межличностных отношениях, манере поведения); загрязнение языка (использование сленга, ненормативной лексики, словпаразитов и т.д.); формирование образцов поведения, чуждых нашей культуре. Значимо 
выше преподаватели оценивают и коррупционные риски, то есть создание в учебном заведении атмосферы, когда все вопросы можно решить за деньги.

Студенты значимо выше, чем преподаватели оценивают риски, связанные с организацией учебно-воспитательного процесса: большие учебные нагрузки; нехватка времени; неудобное расписание, информационно-психологические перегрузки; необходимость участвовать в неинтересных студенту внеучебных мероприятиях.

В оценке социально-психологических рисков, связанных с межличностными отношениями в контексте образовательной среды и особенностями педагогического общения, также наблюдается значимое расхождение мнений студентов и преподавателей. Обе группы респондентов считают серьезной угрозой возможность алкоголизации учащихся, наркоманию, вовлечения в криминальную деятельность. Однако студенты значимо выше оценивают такие факторы как оторванность обучения от реальной жизни; предвзятое отношение преподавателей к студентам; потеря студентами интереса к обучению из-за неинтересных, скучных занятия; низкая доступность информационных ресурсов; непонятное для студентов объяснение материала, неадекватная система контроля знаний, негативные отношения в студенческой группе, проблемы в отношениях с другими людьми, недооценивание преподавателями и однокурсниками способностей и возможностей студента, сексизм, события личной жизни (проблемы в отношениях с партнером, с друзьями, однокурсниками, родителями), беспорядочные половые связи, необдуманный ранний брак, нежелательная беременность. В свою очередь, преподаватели выше оценивают риски вовлечения учащихся в криминальную деятельность (наркоторговля, проституция и т. д.) и игроманию.

Студенты значимо выше, чем преподаватели, оценивают и риски, связанные со здоровьем и самочувствием учащихся, такие как эмоциональная напряженность, стресс, низкая физическая нагрузка, нездоровое питание, невозможность хорошо отдохнуть.

Значимые различия наблюдаются и в оценке рисков, обозначенных нами как собственно психологические, определяемые личностными особенностями субъектов образовательной среды: невозможность для студента реализовать себя в рамках университета; неумение самостоятельно решать свои проблемы в отрыве от семьи; проблемы с самоопределением после окончания университета, с самореализацией в данной профессии; слабое знание и учет своих способностей, склонностей и интересов; неясное представление о будущей профессии; отсутствие мотивации в выборе профессии; необоснованность мотивации в выборе учебного заведения; низкий уровень познавательной активности; недостаточная мотивация к личностно-профессиональной и творческой самореализации и самовыражению; отсутствие потребности в непрерывном образовании; неумение распределять время и организовать учебную работу.

Результаты исследования гендерных и возрастных особенностей представлений студентов и преподавателей о выраженности рисков образовательной среды вуза показали, что гендерных различий в оценке рисков нет, а связь оценки рисков с возрастом респондентов имеется. Результаты корреляционного анализа показали, что чем старше студент, тем выше он оценивает риски «зависимость от соцсетей», «загрязнение языка» и «формирование образцов поведения, чуждых нашей культуре» $(\mathrm{p} \leq 0,05)$. Также чем старше преподаватель и больше его педагогический стаж, тем выше он оценивает риск утраты культурных традиций и социальных норм в образовательной системе. Соответственно, в процессе приобретения жизненного опыта как для студентов, так и для преподавателей становится более значимым фактор сохранения культурной самобытности как составляющая субъективного благополучия.

На основании результатов эмпирического исследования можно сделать следующие выводы. Студенты значимо выше оценивают большинство рисков образовательной среды, чем преподаватели, особенно социально-психологические и собственно психологические риски. Значительной проблемой студенты считают и ситуацию с самоопределением после окончания университета и самореализацией в профессии, что расширяет границы 
проблематики психолого-педагогической безопасности, включая в эту область жизненные перспективы и представление о будущем. Преподаватели вуза считают наиболее серьезными риски, связанные с внешним воздействием на студентов и неумение учащихся противостоять внешнему воздействию, рассматривая студентов как социально незрелых личностей. При этом преподаватели высоко оценивают принципы и организацию учебно-воспитательного процесса в вузе и нее видят проблем студентов, связанных с адаптацией в образовательной среде, отношениям со сверстниками и недостаточной учебной мотивацией.

Таким образом, применение принципов субъектно-бытийного подхода позволяет рассмотреть проблему рисков образовательной среды вуза с разных позиций, создавая целостную картину основных проблем психолого-педагогической безопасности современного вуза.

\section{Литература}

1. Проблемы психологической безопасности/ отв. ред А.Л. Журавлев, Н.В. Тарабрина. М.: Изд-во «Институт психологии РАН», 2012.

2. Фоменко Г. Ю. Психология безопасности личности: теоретико-методологические основания институционализации // Человек. Сообщество. Управление. 2010. №1 . С. 83-99.

3. Безопасная образовательная среда: психолого-педагогические основы формирования, сопровождения и оценки: монография; под науч. ред. И.А. Баевой, С.В. Тарасова. СПб.: ЛОИРО, 2014. 269 с.

4. Арендачук И.В. Копинг-стратегии студентов как факторы преодоления рисков образовательной среды вуза // Национальная ассоциация ученых (НАУ). № (10), 2015. С. 87 90.

5. Лялюк A.В., Тучина О.Р. Риски образовательной среды современного вуза//Инновационные процессы в высшей школе: материалы международной научнопрактической конференции, посвященной 100-летию ФГБОУ ВО «Кубанский государственный технологический университет». Краснодар: Изд. ФГБОУ ВО «КубГТУ», 2018. С. $113-115$.

6. Лялюк А.В., Иванова Н.Г. Некоторые конструктивные решения обеспечения безопасности образовательной среды // Балтийский гуманитарный журнал. 2018. Т. 7. № 2(23). C. 243-246.

Фролов А.А.

\section{БЕЗОПАСНОСТЬ В СОВРЕМЕННОМ ОБЩЕСТВЕ: ДОСТОЯНИЕ КАЖДОГО ИЛИ ПРИВИЛЕГИЯ ИЗБРАННЫХ?}

«Что дозволено Юпитеру, не дозволено быку» крылатое латинское выражение [7]

Жизнь человека в современном обществе сегодня наполнена большим количеством угроз и опасностей. Казалось бы, развитие общества должно закономерно привести к снижению опасных факторов для его населения, увеличению средств защиты и повышению состояния безопасности. В самых общих чертах, можно сказать, что различные научные достижения общее состояние безопасности значительно повысили - в прошлое ушли массовые эпидемии и масштабные войны, был искоренен расовый и половой геноцид, доступными стали информационные ресурсы и технологии. Однако, если посмотреть детально, безопасность современности продолжает оставаться избирательной, неравной и привилегированной. В нашей статье мы не будем касаться глобальных мировых проблем, типа грядущих экологических и техногенных катастроф, демографического взрыва или затяжного экономического кризиса, а постараемся оценить степень бытовой защищенности человека в современном обществе и определить причины ее неравенства.

Здравоохранение. По данным министерства здравоохранения показатель смертности младенцев при рождении в России за последние пять лет снизился с 17,8 на 1000 родившихся 
в 1990 году до 5,9 на 1000 родившихся в 2018 году [3]. Изменился и средний возраст рожениц - произошло увеличение на пять лет с 25 лет по состоянию на 1990 год, до 30 на 2018 год [4]. Смертность рожениц во время родов также снизилась с 52,4 на 100000 живорожденных в 1991 году, до 7,3 в 2017 году [7]. Статистические данные указывают на повышение общего качества сферы медицинского обеспечения граждан нашей страны. При том, что сфера платного медицинского обслуживания продолжает набирать обороты и является доступной в настоящее время только для обеспеченной категории населения, не может не радовать тот факт, что общий уровень бесплатного медицинского обслуживания сферы акушерства и гинекологии за последние три десятилетия значительно повысился. Примечательно, что показатель причин смертности детей до 5 лет в зависимости от уровня доходов населения оказался ниже в семьях с низкими доходами и выше в семьях с высокими по причинам недоношенности, врожденных аномалий и травм, однако обратное соотношение наблюдается по причинам пневмонии, асфиксии при родах и неонатальном сепсисе. Эти данные демонстрируют, что качество медицинского обслуживания у более обеспеченных семей значительно выше общедоступного, поэтому и риски смертности, которым подвержены дети из малоимущих семей, у них ниже. Более обеспеченные семьи создают более комфортные условия жизни для своих детей. Вместе с тем, причины недоношенности и врожденных аномалий наблюдаются у беременных в слишком юном (до 18 лет) и слишком зрелом (до 35 лет) возрасте, заядлых курильщиц и пристрастившихся к алкоголю [1, 4].

Несколько иной является картина в сфере общего медицинского обслуживания населения. По данным Федеральной службы государственной статистики за последние три десятилетия общая численность специалистов-медиков в России существенно не изменилась. В 1990 году в стране насчитывалось 667,3 тысяч специалистов, в 2015 году это количество составило 673 тысячи медработников [5]. Несмотря на то, что общая численность населения страны за это время существенно не изменилось, сфера бесплатного и коммерческого здравоохранения в настоящее время сильно отличается. Контрастные различия касаются не только качества общего медицинского обслуживания, но и квалификации работающих специалистов. В частности, треть населения в 2017 году вынуждены обратиться в платные медицинские учреждения по причине сокращения времени попадания на прием и качества получаемых услуг [2]. В бесплатной поликлинике вы будете вынуждены записаться на прием, а затем еще отстоять очередь к специалисту непосредственно в день приема. И, в большинстве случаев, день приема не совпадает с днем обращения (в некоторых случаях ожидание может доходить до месяца). Кроме того, не редкими стали явления отсутствия необходимых специалистов в бесплатном учреждении и их наличие в частных организациях. Таким образом, качество здравоохранения в настоящее время очень сильно является зависимым от уровня достатка населения. Обеспеченный человек, чувствует себя более защищенным, он может себе позволить выбрать специалиста, у которого он будет обслуживаться, конкретное учреждение, город, в котором оно находится или даже страну.

Жилье. Обеспечить безопасность жизни и здоровья в своем жилище сегодня может далеко не каждый. И причина кроется также в уровне достатка, который позволяет повысить этот уровень защиты. Начиная непосредственно с вида жилья - будь это комната в коммуналке с местами общего пользования или квартира в фешенебельном доме с частной охраняемой придомовой территорией и консьержем, и заканчивая современными средствами охраны и противопожарной безопасности - все становится более доступным, если у тебя есть такая финансовая возможность. Как, никогда, сегодня актуально выражение: «Мой дом - моя крепость!» [6]. И чем прочнее эта крепость, тем более защищенным в ней чувствует себя человек. Вот только построить эту крепость себе может позволить далеко не каждый.

Безопасность на улице. Вспомните свое последнюю прогулку по городу - вы двигались пешком, передвигались на общественном транспорте или в личном автомобиле? У вас были при себе средства защиты от хулиганов или вас сопровождала частная охрана? Где и в какой ситуации вы будете себя чувствовать больше в безопасности - в общедоступном месте или 
зоне ограниченного посещения? И почему? Ответ также очевиден - у некоторых есть больше возможности чувствовать себя более защищенными в общественных местах исходя из собственных возможностей, чем у большинства остальных, которые могут полагаться только на собственные силы или, в лучшем случае, рассчитывать на силы находящихся рядом людей.

Образование. В наши дни человек с необходимым высшим или средне специальным образованием способен подняться на достаточный уровень жизни и безопасности в обществе, человек с общешкольным образованием или без него находится в низших слоях социальных страт. Наличие высшего образования при устройстве на работу сегодня рассматривается как обязательный критерий, а не как предпочтительный те же тридцать лет назад. В связи с чем, система современного образования была довольно быстро перестроена на коммерческие рельсы. С одной стороны, это можно рассматривать как закономерный шаг выживания системы в после перестроечный период при сокращении государственного финансирования. С другой стороны, это открыло дополнительные возможности для более обеспеченной части населения. Обучаться в престижном лицее и поступить в желаемый ВУЗ теперь гораздо проще тем, у кого на это есть дополнительные средства. Объем знаний обучающихся детей они, как показывает практика, существенно не увеличивают, однако обеспечивают получение гарантированного диплома при посредственных способностях за счет системы внебюджетного финансирования. Таким студентам не нужно корпеть над учебниками в стремлении получить высшую оценку, ведь родители оплачивают их минимальный уровень подготовки.

Подводя итоги размышлений, картина безопасности личности в обществе представляется неоднородной, можно сказать, двухуровневой - первый, базовый уровень, доступный по умолчанию для всех граждан государства, и второй, привилегированный, относящийся к обеспеченным слоям населения. Произведенные выводы не являются открытием, в связи с тем, что социальное неравенство в обществе насчитывает многовековую историю и до достижения безопасного настоящего для всех еще очень далеко. Однако, с сожалением приходиться констатировать, что технические и информационные открытия современности не столько устраняют существующие различия, сколько их усиливают.

\section{Литература}

1. Недоношенный ребёнок - шансы выжить: [Электронный pecypc]. URL: https://viline.tv/deti/article/nedonosennyj-rebenok-sansy-vyzit-na-raznyh-srokah (Дата обращения: 07.09.2018);

2. Нодельман В., Беришвили Н. Россияне считают платные медуслуги более качественными: [Электронный ресурс]. URL: https://iz.ru/708435/valeriia-nodelman-nataliiaberishvili/rossiiane-schitaiut-platnye-meduslugi-bolee-kachestvennymi (Дата обращения: 07.09.2018);

3. Список стран по уровню младенческой смертности: [Электронный ресурс]. URL: https://ru.wikipedia.org/wiki/Список_стран_по_уровню__ младенческой_смертности (Дата обращения: 07.09.2018);

4. Суханова Л.П. Статистика службы родовспоможения в России (по данным форм ГСН №13, 32, 47): [Электронный pecypc]. URL: http://mednet.ru/images/stories/files/ statistika/for_miac/LP_Suhanova_Rodovspomozhenie.pdf (Дата обращения: 07.09.2018);

5. Численность врачей по специальностям в России с 1970 по 2015 (Таблица): [Электронный ресурс]. URL: http://infotables.ru/statistika/72-obrazovanie-i-zdravookhranenie-vrossii/796-chislennost-vrachej-po-spetsialnostyam \#hcq=56b2p7r (Дата обращения: 07.09.2018);

6. Энциклопедический словарь крылатых слов и выражений. - М.: «Локид-Пресс». Вадим Серов. 2003.

7. Quod licet Iovi, non licet bovi: [Электронный pecypc]. URL: https://ru.wikipedia.org/wiki/Quod_licet_Iovi,_non_licet_bovi (Дата обращения: 07.09.2018). 


\section{ПРОБЛЕМА КОНСУЛЬТИРОВАНИЯ РОДИТЕЛЕЙ - УЧАСТНИКОВ ВЫСОКОКОНФЛИКНЫХ РАЗВОДОВ В ПОСТЭКСПЕРТНЫЙ ПЕРИОД СОПРОВОЖДЕНИЯ}

С каждым годом количество разводов возрастает. В России распадается каждый третий брак. Еще большее сожаление вызывает процент высококонфликтных разводов. Именно такие разводы, как правило, оказываются в поле зрения психологов-экспертов ввиду того, что возникающие споры о воспитании детей и порядке общения с ними решаются путем обращения в суд. Суд в свою очередь обращается за помощью к психологам и назначает судебную психологическую экспертизу или комплексную психолого-психиатрическую экспертизу в рамках производства по гражданскому делу.

После направления заключения в соответствующий орган работа психолога может быть окончена. Далее психолог может быть привлечен к дальнейшему психологическому сопровождению ребенка и его законных представителей: разработке рекомендаций по оптимизации отношений «ребенок-взрослый», организации коррекционно-развивающей работы.

Сопровождение родителей психологом, проводящим психологическую экспертизу и уже имевшим дело с данной семьей, имеет ряд преимуществ.

Во-первых, одна из сторон (либо оба родителя) уже знакомы со специалистом и чувствуют себя в большей безопасности в такой кризисной ситуации как развод, и им нет нужды еще раз проходить первичные этапы знакомства и выяснения запроса с новым специалистом.

Во-вторых, психолог в полной мере знаком с сутью проблемы, так как проводил экспертизу. Ему известна вся ситуация, а также особенности личности родителя (родителей)/ребенка и их взаимоотношения в семье. Это дает психологу большое преимущество и позволяет более успешно справится с задачей и максимально помочь семье пережить кризис.

В-третьих, психолог-эксперт в достаточной степени должен быть осведомлен в правовых вопросах, что также позволяет ему оказывать максимальную помощь семье в период бракоразводного процесса.

Психолог-эксперт, обсуждает со сторонами развода варианты психологической помощи (после завершения процессуальных действий) и, при необходимости, согласует привлечение другого специалиста-психолога.

Одним из видов психологической помощи, оказываемой разводящимся людям, является психологическое консультирование. Его важность определяется тем, что любой развод, даже по обоюдному согласию супругов, представляет собой серьезную травму, которая усугубляется необходимостью полной реорганизации жизни.

Консультирование тех, кто принял решение расторгнуть брак, отличается от других видов психологической коррекции ярко выраженной информирующей функцией. Поэтому специалисты, работающие с разводящимися супругами, должны быть хорошо осведомлены в области юридических аспектов развода и особенно в вопросах, связанных с детьми. Любой развод, даже желанный, - серьезная травма, которая усугубляется необходимостью полной реорганизации жизни и переживается иногда долгие годы.

Консультирование родителей в постэкспертный период сопровождения является необходимым условием для более безопасного прохождения этого сложного периода в жизни человека. В такие моменты люди часто находятся в депрессивном, агрессивном, стрессовом состоянии, при котором довольно сложно решать самостоятельно вопросы, касающиеся не только отношений между собой, но и тем более отношением с ребенком (детьми). 
Необходимо учитывать, что при высококонфликтных разводах в большей степени страдают дети. В такие моменты им нужна поддержка самых близких - родителей, которые либо заняты конфликтом друг с другом и не обращают внимания на ребенка, либо, еще хуже, используют его как прикрытие или возможность надавить, шантажировать супруга. В такие моменты психолог при сопровождении таких родителей может помочь им, направить, поддержать, а также обратить их внимание на ребенка и сгладить такой сложный период в их жизни.

Анализ постэкспертных ситуаций показал, что в период после процесса стороны (родители, включённые в высококонфликтный развод) чаще всего обращаются к психологу по вопросам переживаний вследствие несоблюдения одной из сторон решения суда о порядке общения с ребёнком. И, хотя на первый взгляд формулировка запроса выглядит как правовой вопрос, но обращения к психологу связаны именно с психологическими переживаниями негативного характера.

Поэтому мы полагаем, что данное направление психологического консультирования может выступать специфическим предметом исследования психологов и дать информацию о вариантах эффективного сопровождения сторон в периоды после высококонфликтного развода.

Литература:

1. Видра Д. Помощь разведенным родителям и их детям. М.: Изд-во института психотерапии, 2000. $400 \mathrm{c.}$

2. Канторович Я. А., Психология свидетельских показаний, Харьков.- 1925.

3. Русаковская О.А., Сафуанов Ф.С., Харитонова Н.К. Актуальные вопросы участия специалистов в судебных спорах о воспитании детей раздельно проживающими родителями // Психология и право. 2011. № 1.

4. Сафуанов Ф.С., Александров М.Ф. Использование психологических знаний в непроцессуальной форме при судебных спорах между родителями о воспитании ребенка // Юридическая психология. 2011. № 4.

5. Сафуанов Ф.С. Судебно-психологическая экспертиза [Текст]: учебник для академического бакалавриата / Ф.С. Сафуанов. - М.: Юрайт, 2014. -216 с.

Шиповская В.В.

\section{ЛИЧНОСТНАЯ БЕСПОМОЩНОСТЬ В АСПЕКТЕ ПРОБЛЕМЫ ВИКТИМНОСТИ СУБЪЕКТА}

Виктимизация как психологический процесс приобретения виктимности, создающий предпосылки для превращения личности в жертву (буллинга, преступлений, тоталитарных сект и религиозных движений, экстремистских организаций, травмирующих реформ и пр.), широко распространяется в обществе, оформляясь в результате взаимодействия микро- и макросоциальных детерминант и внутренних факторов - беспомощности, безнадежности, отчуждения, ущербной объектной коммуникации с миром. В связи с этим, М. Селигман отмечает, что современная психология по сути дела стала виктимологией [18].

Но следует задать вопрос, почему одни люди могут сопротивляться негативным воздействиям и преодолевать опасности, а другие, стремясь к самосохранению, выбирают путь пассивного подчинения обстоятельствам, который однозначно приводит к деградации и разрушению личности? Ответ на поставленный вопрос мы соотносим с субъектно-бытийным подходом, позволяющим в экзистенциально-онтологическом контексте анализировать психологические механизмы пассивности и подчинения, разрушающие личность и превращающие человека в жертву.

Рассматривая источники виктимности в контексте предпочитаемого модуса бытия (экстремального или предельного) [10], мы обращаемся к личности как к субъекту бытия. 
Субъектно-бытийная методология, где личностное бытие рассматривается как следствие субъектной активности, саморегуляции и самоорганизации $[2 ; 3 ; 4 ; 8]$, дает возможность рассмотреть процесс виктимизации в онтологическом аспекте, в контексте многопланового рассмотрения различных факторов, его обусловливающих.

Вариаций форм виктимности очень много. Информацию о различных способах проявления виктимности - некритичности, излишней доверчивости/самонадеянности, нежелании преодолевать собственное бессилие и активно сопротивляться негативным обстоятельствам мы находим в библейских сюжетах, древнегреческих мифах [7], а также в сказках, где описаны разнообразные виктимологические ситуации и их заложники.

Несмотря на то, что практически всегда есть альтернатива - подчиниться или оказать сопротивление, превозмочь страдания, герои этих мифов и сказок склоняются перед преследователем. Причем, этот экзистенциальный выбор делают они сами, вследствие страха, который сковывает их волю и приводит к поражению или смерти. Анализ архетипических сюжетов, образов и ситуаций, где герои попадают в ловушку и становятся жертвами, открывает существенный признак феномена виктимности - внутреннее бессилие, социальный инфантилизм, покорность обстоятельствам, неадекватное тестирование реальности.

Французский психолог и социолог Жак Семлен, размышляя о причинах насилия и способах его преодоления, считает, что человек перед лицом опасности всегда выбирает один из трех вариантов: 1) полностью принимает сторону угнетателя, проявляя готовность к сотрудничеству; 2) не желая делать окончательный выбор, приспосабливается к системе, замыкаясь в спасительных приземленных ценностях и чувствуя себя в псевдобезопасности; 3) уверенный в том, что можно изменить свой образ жизни, избирает путь сопротивления и тем самым спасает человеческое достоинство [1, С. 76-77]. Третий вариант, препятствующий виктимности, предполагает большую духовную работу по осознании своего достоинства и способности действовать.

Реальная угроза виктимизации касается преимущественно тех, кто реализует модус беспомощности $[13 ; 16 ; 17]$ - самый непродуктивный способ совладания со сложностью и неопределенностью, связанный с пассивной, пораженческой позицией, общим итогом которого становится неуспех во всех жизненных сферах. Фундамент такого патологического, деструктивного модуса бытия формируется в детские годы под воздействием негативной социализации, прежде всего, травмирующих семейных факторов - эмоционального отчуждения матери, гиперопеки/гипоопеки [14].

Личностная беспомощность, при которой сильно снижаются шансы обнаружить в себе личностные ресурсы сопротивления травматическим обстоятельствам, проявляется в негативном прогнозировании собственной субъектной активности, субъективном ощущении утраты влияния на повседневные события, в переоценке личностных ресурсов и требований ситуации, оцениваемой как безвариантная и неподконтрольная [15]. Равнодушие, бездеятельность, боязнь трудностей и испытаний, конформизм и неспособность оказать активную помощь другим, неумение выделить и осмыслить сложную ситуацию, исходя из анализа системы разноуровневых противоречий, являются индикаторами беспомощзности.

Проявления беспомощности, при которой опасность виктимизации многократно возрастает, зависят от специфики вызывающих ее ситуаций. Если обратиться к характеристикам ситуации, то именно ее высокая неопределенность, где требуется большая вариативность индивидуальных стратегий и поведенческих практик, у субъектов с модусом беспомощности вызывает панику, непереносимость, шок и пассивную капитуляцию.

Анализ поведения человека в граничных ситуациях дает точное и яркое представление о его личности и способности к сопротивлению. В работах В. Франкла применительно к ситуации концлагеря убедительно показано, как трудно, но возможно сохранить личностную автономию и не потерять достоинство в ситуации чрезвычайной и реальной угрозы для жизни. 
Необычная ситуация всегда вызывает чувство страха, которую А. Кемпински определяет как «дезинтеграционный страх», поскольку он вызывается нарушением существующей структуры интеракции. Структура интеракции позволяет предвидеть события, планировать свою активность и в ходе нового события, разрушаясь, формируется заново. Существует определенная граница толерантности к травматичной ситуации, за которой наступает паническая реакция страха и беспомощности, где одно усиливает и поддерживает другое: чувство паники парализует целевую активность, а невозможность действия усиливает страх [5, с. 19]. Разрушение личности, по мнению 3.И. Рябикиной, «связано с нарушением ее целостности, ее расслоением, распадом, сегрегацией отдельных функций, паттернов, систем поведения» [9, с. 251].

А. Кемпински в связи с этим пишет о жуткости и концлагеря, которая ощущалась особенно сильно при первом столкновении с ним. У большинства узников, которых буквально вырвали из привычного и комфортного жизненного мира, наступала кратковременная психическая реакция растерянности, подавленности, беспомощности, на фоне чувств страха, ужаса и одиночества [5].

Капитуляция перед неотвратимой опасностью вызывала две разновидности психогенной смерти: большое число заключенных умерло вскоре после поступления, что говорит о принятии решения отказаться от любого сопротивления обстоятельствам («Я не хочу и не могу в этом участвовать»). Другая форма беспомощной капитуляции получила название «мусульманской стадии». Эта стадия обычно наступала спустя некоторое время после нахождения в концентрационном лагере, когда приходили к истощению эмоциональные и физические ресурсы заключенных. Покорность обстоятельствам приводила человека к состоянию роботизации и психической закрытости, когда заключенные, фактически, теряли человеческий облик. Такому состоянию часто предшествовала деперсонализация, которая представляла собой попытку отрицания реальности и онемения всей эмоциональной сферы [6].

Сопоставляя обе формы психогенной смерти, В. Франкл считает, что они были вызваны потерей смысла жизни, которая является подлинной трагедией для человека. Вместе с тем, пишет В. Франкл, были люди, которые в этих невыносимых условиях бытия смогли выжить, поскольку смогли увидеть смысл даже в этой трагической ситуации, осмыслить свою жизнь в контексте ценностей отношения. Совесть помогала заключенным осознавать и отыскивать уникальный смысл, кроющийся, по сути, в каждой ситуации $[11 ; 12]$.

Именно тернистый путь сопротивления обстоятельствам, предполагающий доверие к себе и веру в бога, позволили трансцендировать ужасы существования, придать страданию смысл, и более того, трансформировать себя из экзистенциально больного человека в экзистенциально здорового. В результате подобного преобразования своей личности заключенные смогли спасти свою жизнь и жизни своих товарищей, жить полноценной жизнью после освобождения.

Приверженность нравственному, религиозному идеалу, преобразование разрушительных социальных противоречий в развивающие (самотрансценденция) препятствует формированию виктимности. Соответственно, мера и ценностная направленность преодоления заданных обстоятельств не только проявляет специфику повседневных практик, но и формирует способ организации субъектной активности личности.

В эмпирическом исследовании мы изучали последствия переживания беспомощности и пессимизма для личности, находящейся на этапе самоопределения. Предполагалось, что личностная беспомощность, самоизоляция и пессимизм препятствует становлению и устойчивости субъектной позиции, становится фактором виктимизации.

Обнаружено, что подростки с выраженной беспомощностью неспособны к продуктивным контактам и сотрудничеству, что говорит о неразвитости социальных чувств, отсутствии социального интереса. Склонность к неконструктивному разрешению конфликтов в сфере личностно-эмоциональных взаимоотношений приводят к закономерному результату деструктивности и дисгармоничности всех бытийных пространств личности. Примитивность 
смысложизненных установок и целей, отрицание высших ценностей, некомпетентность в ситуациях межличностного взаимодействия препятствуют пониманию складывающихся сложных обстоятельств, контролю над ними, не позволяют разрешать и преобразовывать противоречия. В центре этих бытийных противоречий оказывается проблема, связанная $c$ формообразованием модуса бытия личности. Следовательно, анализируя беспомощность и сопутствующие ей феномены (пессимизм, агрессивность, манипулятивность), мы выходим на потенциал субъектности и можем установить, в какой мере личность подвержена виктимности.

Представляется чрезвычайно востребованным разработка и последующее внедрение специальных техник превентивной работы с потенциальными жертвами, в том числе буллинга, кибербуллинга, деструктивных сект, а также усовершенствование технологий психологической поддержки с пострадавшими - реальными жертвами насилия, манипуляции и пр. Эти гуманистические технологии должны быть нацелены на преодоление экзистенциальной беспомощности, достижение автономии, сохранение достоинства личности и понимание субъектом персональной ответственности.

Таким образом, раскрытие созидательного потенциала субъектности и сильных сторон личности подрывает веру в то, что субъект всегда будет жертвой жизненных обстоятельств, вследствие чего появляется гордость за свою жизнь и снижается вероятность появления личностной виктимности.

\section{Литература}

1. Глобальные проблемы и общечеловеческие ценности / Пер. с англ. и фр. М.: Прогресс, 1990. $495 \mathrm{c}$.

2. Гусейнов А.Ш. Психология протестной активности личности / монография. Краснодар: КГУФКСТ. 2017. 488 с.

3. Гусейнов А.Ш., Рябикина 3.И., Фоменко Г.Ю., Шиповская В.В. Феномен протестной активности личности: субъектно-бытийная интерпретация // Российский психологический журнал. Том 14, № 4, 2017. С. 78-96.

4. Гусейнов А.Ш., Фоменко Г.Ю., Рябикина З.И. Протестная активность личности в контексте субъектно-бытийного подхода // Человек. Сообщество. Управление. 2015. (16) №3. C. 6-21.

5. Кемпински А. Экзистенциальная психотерапия. М., 1998. 320 с.

6. Кристал Г. Интеграция и самоисцеление. Аффект, травма и алекситимия. М.: Институт общегуманитарных исследований. 2006. 800 с.

7. Кун Н.А. Легенды и мифы Древней Греции и Древнего Рима. М: АСТ. 2017. 504 с.

8. Рябикина 3.И. Психология саморегуляции с позиции субъектно-бытийного подхода // Психология саморегуляции в XXI веке. СПб.; М.: Нестор-История, 2011. С. 126-141.

9. Рябикина 3.И. Субъектно-бытийный подход к пониманию личности: содержание и теоретико-методологические основания / Знаков В.В., Рябикина З.И. Психология человеческого бытия. - Смысл, 2017. 416 с. С. 195-315.

10. Фоменко Г.Ю. Модусы бытия личности: к вопросу о содержательных основаниях дифференциации // V съезд Общероссийской общественной организации «Российское психологическое общество». Материалы участников съезда. Т. 3. М.: Российское психологическое общество, 2012. с. 327.

11. Франкл В. Доктор и душа СПб.: Ювента, 1997. 285 с.

12. Франкл В. Человек в поисках смысла. - М.: Прогресс, 1990. - 368 с.

13. Шиповская В.В. Деструктивные аспекты проявления личностной беспомощности: междисциплинарный подход / Психология опасности и безопасности. В 2-х книгах. Книга вторая: Психологические модели субъектности и безопасности социального субъекта (Ч.3, Ч.4) / Под ред. С.Н. Тесля, И.Б. Шуванова. Сочи, РИЦ СГУ, 2012. С. 253-267.

14. Шиповская В.В. Беспомощность: теория, эксперименты, практика. Краснодар: ИЭиУ МиСС, 2009. 245 c. 
15. Шиповская В.В. Отчуждение и экзистенциальная беспомощность подростков как показатели неаутентичности личностного бытия // Личность и бытие: человек как субъект социокультурной реальности: материалы Всероссийской научно-практической конференции / под ред. 3.И. Рябикиной и В.В. Знакова. Краснодар: Кубанский гос. ун-т, 2016. С. 270-273.

16. Шиповская В.В. Беспомощность как фактор формирования экстремистских установок в подростковой среде // Казанский педагогический журнал, 2017. № 5 (124). С. 125-131.

17. Шиповская В.В. Модус преодоления и модус беспомощности как разные способы формообразования бытия личности // Материалы съезда Российского психологического общества / сост. Л.В. Артищева; под ред. А.О. Прохорова, Л.М. Попова, Л.Ф. Баяновой и др. - Казань: Изд-во Казан. ун-та, 2017. - Т. 3. - 104 с. С. 69-71.

18. Sheldon K.M., King L. Why positive psychology is necessary. American Psychologist, 56, 2001. P. 216-217. 


\title{
ЧАСТЬ ІІ. МАТЕРИАЛЫ КРУГЛОГО СТОЛА «СУБЬЕКТНЫЙ ПОДХОД К РАССМОТРЕНИЮ ПРОБЛЕМ ЛИЧНОСТИ И ЕЕ БЫТИЯ: ОТВЕТ НА ВЫЗОВЫ СОВРЕМЕННОСТИ».
}

Андриенко Т.А., Лабунская В.А., Шкурко Т.А.

\section{СУБЪЕКТНО-ЛИЧНОСТНЫЕ КОМПОНЕНТЫ «МНОГОФАКТОРНОЙ МОДЕЛИ ИЗУЧЕНИЯ ОТНОШЕНИЯ К ВНЕШНЕМУ ОБЛИКУ ФРУСТРАЦИИ ЦЕННОСТИ ВНЕШНЕГО ОБЛИКА НЕГАТИВНЫМИ ОЦЕНКАМИ ДРУГИХ*}

\begin{abstract}
* Исследование выполнено при поддержке Российского научного фонда, проект № 17-18-01260 «Социальная психология внешнего облика: функции, значимость, удовлетворенность, обеспокоенность, интерпретации в межличностном и внутригрупповом взаимодействии в молодежной среде»
\end{abstract}

Введение. В современной психологии внешнего облика уделяется огромное внимание изучению различных феноменов, сопряженных с внешним обликом человека. Первое место занимают исследования, в которых рассматривается проблема удовлетворенности внешним обликом, а также работы, в которых анализируется влияние оценок и самооценок внешнего облика на удовлетворенность и обеспокоенность внешним обликом (обзоры этих работ представлены в наших публикациях [6,20,21]).

Необходимо, еще раз подчеркнуть, что в обыденной жизни оценка Другого - это установление взаимосвязей между внешним обликом и психологическими, социальнопсихологическими особенностями личности, что такого рода оценки являются значимыми, эмоционально-насыщенными феноменами, регулирующими переживания и взаимоотношения людей различных социальных групп, что знак и содержание оценок зависят от «социального фокуса воспринимающего, его перцептивных умений и предпринимаемых действий» [13,с.47]. В этом контексте ставится вопрос об особенностях личности наблюдателя, вопрос об адекватности межличностного восприятия [2]. При всей важности постановки данных вопросов, понимания роли «социального фокуса» в возникновении определенного знака оценки личности на основе ее внешнего облика, отношения к внешнему облику, важно согласиться с тем, что оценка внешнего облика всегда будет пристрастной, недостаточно адекватной, не совпадающей с самооценками, следовательно, будет в той или иной мере фрустрировать человека, на которого направлены эти оценки, порой восприниматься, как негативные, заставляющие выбирать виды ответных реакций в процессе взаимодействия.

Учитывая эмоциональную нагруженность оценок внешнего облика, функциональную значимость внешнего облика в различных сферах взаимодействия, исследователи обращаются к изучению обратной связи $[17,18]$, которую дают Другие, вглядываясь во внешний облик человека, к рассмотрению комментариев $[15,19]$, направленных на внешний облик другого человека. В исследовании L. J.Carriere, A.S.Kluck [15] установлено, что существуют значимые положительные корреляции между негативными комментариями и мерой неудовлетворенности телом, позитивные замечания, направленные на внешний облик человека, на его вес, образуют взаимосвязи с показателями удовлетворенности взаимоотношениями.

Постоянно отмечается, что, несмотря на «социальное давление», большую роль в восприятии, интерпретации, отношении к внешнему облику играют социальнопсихологические, личностные факторы, так называемая «новая субъектность», порожденная современными условиями бытия. Негативное отношение к своему внешнему облику, к его физическому компоненту обусловлено, по мнению исследователей [14], высоким уровнем 
нейротизма, а экстравертированность и добросовестность способствуют формированию положительного образа своего внешнего облика. Пристальное внимание к физическим аспектам внешнего облика, постоянная «объективизация» внешнего облика, в том числе за счет посылаемой обратной связи, включающей оценки внешнего облика, влияет на снижение удовлетворенности внешним обликом, на формирование «стыдливого» отношения к нему [22]. Разработанные психометрические процедуры указывают на то, что такие составляющие отношения к внешнему облику, как стыд, вина, «подлинная» и «высокомерная» гордость являются взаимосвязанными [16]. Иными словами, представленность внешнего облика в пространстве бытия человека может увеличивать обеспокоенность им, в частности, за счет негативного оценивания и эскалации фрустратрационных реакций на эти оценки, приводить к поиску способов, приемов снижения фрустрации, вызванной оценками внешнего облика.

Методология исследования. Проблема изучения чувства неловкости, ассоциированного с внешним обликом, формирования тревоги, обеспокоенности, неудовлетворенности им, традиционно, рассматривается в контексте взаимовлияний макро и микро социальных факторов $[1,3,9,11,12]$. Нами была предпринята попытка систематизации различных факторов, определяющих оценки, самооценки внешнего облика, переживаний, связанных с ним [5,7,20,21]. Одна из первых эмпирических моделей изучения отношения к внешнему облику была разработана нами совместно с Е.В. Капитановой [4]. Уже в этой «эмпирической модели» в качестве факторов, определяющих отношение к внешнему облику, в частности, удовлетворенность и обеспокоенность им, рассматривались оценки внешнего облика друзьями и родителями, а также групповые оценки внешнего облика, оценки внешнего облика «значимыми/не значимыми оценщиками внешнего облика - членами группы». Как показало исследование [7], оценки значимыми другими, представления молодых людей о том, как оценивался родителями, друзьями их внешний облик, являются сильнейшими факторами удовлетворенности своим внешним обликом. Иными словами, в этом исследовании были получены данные, которые указывают на роль оценок внешнего облика Другими в формировании отношения к своему внешнему облику. Вместе с этим, такой тип исследований, раскрывая взаимосвязи между переживаниями, связанными со своим внешним обликом, не учитывает обратную реакцию объекта оценки, негативностьпозитивность оценивания внешнего облика и ее влияние на отношение к внешнему облику. В рамках предлагаемой нами в настоящее время «многофакторной модели изучения отношения к внешнему облику» (см. фрагмент этой «модели» в [8]), в центре которой находится такой фактор, как «ценность внешнего облика», предпринята попытка совмещения субъектно-личностных факторов с социокультурными и социальнопсихологическими факторами. В качестве субъектно-личностного фактора в данной статье рассматривается уровень фрустрации ценности внешнего облика, сопровождаемый спектром переживания, вызванных негативными оценками Другого.

В исследовании проверялась гипотеза о влиянии уровня выраженности фрустрации на негативные оценки внешнего облика Другими на обеспокоенность, удовлетворенность внешним обликом, на самооценки компонентов и характеристик внешнего облика. В исследовании приняли участие 66 человек: 24 мужчины и 42 женщины в возрасте от 25 до 35 лет. Выбор данного возрастного диапазона обусловлен повышением сензитивности к внешнему облику, усилением выраженности «телоцентрации» и приданием функциональной значимости внешнего облика в связи с выстраиванием профессиональной карьеры и формирования семейных и иных близких отношений.

Методы исследования: 1.«Вербальный фрустрационный тест» Л.Н. Собчик [10], в который входит наряду с другими ценностями такая ценность, как «внешний вид». С помощью шкалы «внешний вид» диагностируется выраженность фрустрации ценности внешнего облика, круг лиц, оказывающих наибольшее фрустрационное влияние, тип реакции в ситуации фрустрации, иными словами, тип реакции на негативные оценки внешнего облика значимыми и незначимыми другими. Процедура обследования включает в себя не только ответы - высказывания (Что бы я сказал?), но и описание участником 
исследования, переживаемых при этом чувств. Оценка степени фрустрации ценности внешнего облика складывается из суммарных показателей двух категорий: высказывания и чувства. Традиционно, рассматриваются следующие показатели: усредненная оценка степени агрессивности по каждой ценностной категории, в нашем исследовании - это ценностная категория «Внешний облик»; величина агрессии по отношению к мужчинам, фрустрирующим ценность внешнего облика, и величина агрессии по отношению к женщинам, фрустрирующим ценность внешнего облика. 2.Опросник «Оценочносодержательная интерпретация своего внешнего облика», который включает шкалы, соответствующие нашему представлению о много компонентной структуре внешнего облика. Шкалы: эстетические оценки лица; тела; оформления внешнего облика; экспрессивного поведения; интегральные характеристики внешнего облика - шкалы: оценки привлекательности своего внешнего облика для противоположного пола; феминности маскулинности внешнего облика. Респондентам предлагается оценить на основе десяти бальной системы степень соответствия эстетических параметров различных компонентов внешнего облика своему внешнему облику. В исследовании применялись мужской и женский варианты опросника. На основе выше описанной процедуры определялись уровни следующих видов самооценок: 1) самооценка лица; 2)самооценка телосложения; 3) самооценка оформления внешнего облика; 4) самооценка экспрессивного поведения; 5) самооценка привлекательности внешнего облика для противоположного пола; 6) самооценка феминности/маскулинности внешнего облика. Интегральная самооценка внешнего облика рассчитывалась на основе суммирования баллов по каждому виду самооценок и деления суммы баллов на число видов самооценок. 3.Анкета: «Отношение к своему внешнему облику: удовлетворенность и обеспокоенность» Данная анкета включает 12 шкал. Обеспокоенность внешним обликом оценивалась на основе шкал, которые включали вопросы о том, насколько часто участник исследования испытывает чувства смущения, неловкости, скованности из-за своего внешнего облика в различных ситуациях взаимодействия? Удовлетворенность внешним обликом определялась на основе шкал, которые включали вопросы о том, насколько участник исследования согласен с тем, что его внешний облик производит приятное впечатление на окружающих; или, например, утверждение: «Мои близкие считают меня привлекательным». Согласие с тем или иным утверждением оценивалось участниками исследования в диапазоне от 1 до 10 баллов. На основе суммирования оценок по двум типам шкал рассчитывались индексы удовлетворенности и обеспокоенности своим внешним обликом.

Математические процедуры: корреляционный анализ, однофакторный дисперсионный анализ, Т - критерий парных выборок, критерий Манна-Уитни.

Результаты и выводы

1.В соответствии с критериями, приведенными в тесте Л.Н. Собчак, в группе участников исследования преобладают те, которые имеют усредненные оценки степени агрессивности в диапазоне от 3 до 4 баллов (75\% участников исследования). В целом, по выборке М=3,3; минимальный показатель $=2,2$; максимальный $=4,6$. Величина агрессии по отношению к мужчинам, фрустрирующим ценность внешнего облика, и величина агрессии по отношению к женщинам, фрустрирующим ценность внешнего облика, значимо отличается (T=-1,936 при $\mathrm{p}=0,05)$. Выраженность агрессивной реакции выше, если фрустрируют ценность внешнего облика женщины. Обращает на себя внимание тот факт, что мера вербальной агрессии (высказывания в ответ на фрустрацию ценности внешнего облика) значимо ниже, чем мера агрессивности, представленная в чувствах и переживаниях объекта негативных оценок $(\mathrm{T}=-5,617 ; \mathrm{p}=0,000)$. Следуя интерпретации оценочных баллов, представленных в тесте Л.И. Собчак, можно сказать, что переживания участников исследования наполнены раздражением и обидой, порой они испытывают гнев (4 балла и выше; 18\% участников исследования). У них появляются чувство неловкости (от 3 до 4 баллов; 60,6\% участников исследования), стыда и смущения (от 2 до 3 баллов; 21\% участников исследования), актуализирующиеся в ответ на фрустрацию ценности их внешнего облика. Гендерный 
фактор не оказывает влияния на выраженность спектра переживаний. U статистика указывает на отсутствие значимых различий между мужчинами и женщинами как по усредненным показателям оценки степени агрессивности, так и по показателям выраженности агрессии в отношении мужчин и женщин, фрустрирующих ценность внешнего облика, по показателям вербальной агрессии (высказывания в ответ на фрустрацию ценности внешнего облика), мерой агрессивности, представленной в чувствах и переживаниях объекта негативных оценок. Можно отметить тенденцию: у женщин все представленные показатели фрустрации ценности внешнего облика несколько выше, чем у мужчин. Женщины испытывают более глубокую фрустрацию ценности внешнего облика и в связи с этим с большей силой проявляют агрессию в ответ на негативные оценки внешнего облика (гневаются, раздражаются, обижаются, стыдятся и смущаются).

2.Интегральная самооценка внешнего облика у участников исследования выше среднего $(\mathrm{M}=7,2)$. Они также достаточно высоко оценивают привлекательность своего внешнего облика для противоположного пола $(\mathrm{M}=7,3)$, феминность или маскулинность внешнего облика $(\mathrm{M}=7,7)$. Гендерный фактор не оказывает существенного влияния на уровень самооценок и характеристик внешнего облика. При этом U статистика указывает на то, что интегральная самооценка внешнего облика, оценки привлекательности своего внешнего облика для противоположного пола, феминности/маскулинности внешнего облика у женщин выше, чем у мужчин.

3.Результаты нашего исследования еще раз подтверждают, что современные молодые люди имеют ниже среднего уровень обеспокоенности внешним обликом $(\mathrm{M}=4,73)$ и выше среднего уровень удовлетворенности им $(\mathrm{M}=7,0)$, исходя из 10-бальной системы оценок. Вместе с этим, уровень удовлетворенности статистически значимо выше, чем уровень обеспокоенности внешним обликом $(\mathrm{T}=-7,23$ при $\mathrm{p}=0,000)$. Значимые гендерные различия в выраженности обеспокоенности и удовлетворенности внешним обликом отсутствуют. При этом, необходимо отметить, что показатель $U$, касающийся различий в выраженности обеспокоенности внешним обликом, свидетельствует о том, что данный показатель выше у женщин $(\mathrm{U}=388,500 ; \mathrm{p}=0,123)$. Результаты этой части исследования указывают на то, что молодые люди - участники исследования, достаточно высоко оценивают различные компоненты своего внешнего облика, они удовлетворены им и не обеспокоены своим внешним обликом.

4.Корреляционный анализ демонстрирует значимые взаимосвязи между самооценкой внешнего облика и удовлетворенностью им $\left(\mathrm{r}=, 633^{* *} \mathrm{p}=, 000\right)$, между самооценкой внешнего облика и обеспокоенностью им $\left(\mathrm{r}=-, 362^{* *} ; \mathrm{p}=, 003\right)$. В тоже время отсутствуют значимые корреляционные взаимосвязи между перечисленными выше показателями и усредненными оценками степени агрессивности, вызванной фрустрацией ценности внешнего облика другими людьми, величиной агрессии по отношению к мужчинам и женщинам, фрустрирующим ценность внешнего облика. Вместе с этим, однофакторный дисперсионный анализ обнаруживает умеренное влияние усредненных оценок степени агрессивности, вызванной фрустрацией ценности внешнего облика другими людьми, а также величины агрессии по отношению к женщинам на удовлетворенность внешним обликом ( $\mathrm{F}=1,539$, $\mathrm{p}=0,111 ; \mathrm{F}=1,252 ; \mathrm{p}=0,272)$. Величина агрессии по отношению к мужчинам, фрустрирующим ценность внешнего облика, оказывает воздействие на обеспокоенность внешним обликом $\mathrm{F}=1,321 ; \mathrm{p}=0,235)$.

5.На все изучаемые показатели отношения к внешнему облику (на самооценки внешнего облика, на обеспокоенность и удовлетворенность внешним обликом) оказывает умеренное влияние величина агрессии, которая была выражена участниками исследования посредством описания чувств, которые они переживали в момент фрустрации ценности их внешнего облика $(\mathrm{F}=1,247 \mathrm{p}=0,261 ; \mathrm{F}=1,063 \mathrm{p}=0,424 ; \mathrm{F}=1,268 \mathrm{p}=0,245)$.

Заключение. Таким образом, можно констатировать, что величина фрустрационных реакций на негативные оценки внешнего облика Другими у большинства участников исследования выражается демонстрацией раздражительности, обиды, стыда, смущения, 
неловкости. Эти переживания появляются, несмотря на то, что они удовлетворены своим внешним обликом, достаточно высоко его оценивают. Молодые люди, испытывая негативные чувства, проявляют агрессию не столько открыто вербально, сколько в скрываемых переживаниях, возникающих в момент фрустрации ценности внешнего облика. Демонстрация вербальной агрессии в ответ на фрустрацию ценности внешнего облика не столько отличается от переживаний, испытываемых в момент негативной оценки внешнего облика, сколько сдвигается спектр агрессивных высказываний в сторону признания вины за свой внешний облик, самообвинения, высказывания оправдательных аргументов. Исходя из этих фактов, можно сделать вывод о том, что в ситуации негативного оценивания внешнего облика, фрустрации ценности внешнего блика, молодые люди - участники исследования, маскируют свое возмущенное, гневливое отношение к Другим, негативно оценивающим их внешний облик. Обозначенный участниками исследований круг переживаний рисует более адекватную картину меры и глубины фрустрации ценности внешнего облика. Эти чувства переживания оказывают влияние на самооценки внешнего облика, на удовлетворенность и обеспокоенность им.

Подводя итоги выполненного исследования, мы констатируем, что выдвинутая нами гипотеза не нашла четкого математического подтверждения на основе корреляционного анализа. Однако, выдвинутая нами гипотеза не может быть опровергнута, так как она подтверждается качественным анализом переживаний участников исследований, описанных ими в момент фрустрации Другими ценности их внешнего облика, а также результатами однофакторного дисперсионного анализа. Субъектный фактор - переживания участников исследования, вызванные негативными оценками их внешнего облика, оказывает влияние на самооценки внешнего облика, на удовлетворенность внешним обликом, на обеспокоенность им. Представленность личностно-субъектных факторов в «многофакторной модели изучения отношения к внешнему облику» предполагает наряду с известными количественными методами, обращение к качественным методам, позволяющим проникнуть в переживания субъекта, которые связаны с его внешним обликом.

\section{Литература}

1. Арина Г.А. Мартынов С.Е. Средства массовой информации как фактор возникновения озабоченности собственной внешностью в юношеском возрасте //Культурно- историческая психология,2009.№ 4. С. 105 -114.

2. Барабанщиков $B$. А.Восприятие личностных особенностей человека по выражению его лица//Социальный и эмоциональный интеллект: От процессов к измерениям. М.: «Институт психологии РАН».2009. С.40-59

3. Дурнева М. Ю., Мешкова Т. А. Влияние социокультурных стандартов привлекательности на формирование отношения к телу и пищевого поведения у девушек подросткового и юношеского возраста // Психологическая наука и образование. 2013. №2. С. 25-34.

4. Капитанова Е. В. Социально-психологические факторы удовлетворенности студентов своим внешним обликом. дисс. ... канд. психол. наук : 19.00.05. -Ростов н/Д., 2017. 212 с.

5. Лабунская В. А., Дроздова И. И. Теоретико-эмпирический анализ влияния социокультурных и социально-психологических факторов на оценки и самооценки молодых людей внешнего облика//Российский психологический журнал. 2017.Т. 14. №2. С.202-226.

6. Лабунская B.А., Капитанова E.B. Обеспокоенность и удовлетворенность студентов своим внешним обликом как предикторы самооценок его компонентов и характеристик // Российский психологический журнал. 2016. Т. 13. № 1. С. 167-183.

7. Лабунская В.А., Капитанова Е.В. Самооценка и оценка внешнего облика членов студенческой группы как предикторы отношений межличностной значимости // Международный научный журнал «Социальная психология и общество. 2016. Том 7. № 1. С. 72-87. 
8. Лабунская В.А., Сериков Г.В. Теоретические основы и методические подходы к изучению феномена «ценность внешнего облика»// Международный научный журнал «Социальная психология и общество. 2018. Том 9. № 3. (в печати).

9. Погонцева Д.В. К проблеме оценки Другого по внешнему облику // Грузинский Электронный Научный Журнал: Образовательные науки (GESJ: Education Science and Psychology). 2011. No.1(18) [Электронный pecypc]. URL: http://gesj.internetacademy.org.ge/download.php?id=1864.pdf\&t=1 [2011.06.30] C. 3-8.

10. Собчик Л. Н. Вербальный фрустрационный тест. СПб.: Речь, 2002. 24 с.

11. Тарханова П.М. Исследование влияния макро и микросоциальных факторов на уровень физического перфекционизма и эмоционального благополучия у молодежи// Культурно историческая психология, 2014, № 1, С.88-94.

12. Шалыгина О.В., Холмогорова А.Б. «Телоцентрированность» современной культуры и ее последствия для психического здоровья детей, подростков и молодежи//Консультативная психология и психотерапия,2015, № 4 (88) С.36-68.

13. Янчук В.А. Межличностная аттракция и детерминирующие ее факторы // Адукацыя і выхаванне. 1998. № 5. С. 53-61.

14. Allen M. S. ,Walter E. E. Personality and body image: A systematic review// Body Image, 2016. Vol.19, December, pp. 79-88.

15. Carriere L. J., Kluck A.S. Appearance commentary from romantic partners: Evaluation of an adapted measure//Body Image, 2014.Vol. 11. Issue 2, pp. 137-145.

16. Castonguay A. L., Sabiston C. M., Crocker P. E., Mack D. E. Development and validation of the Body and Appearance Self-Conscious Emotions Scale (BASES) //Body Image Vol. 11. Issue 2, March 2014, pp.126-136.

17. Dian A.de Vries, Kühne R. Facebook and self-perception: Individual susceptibility to negative social comparison on Facebook// Personality and Individual, Differences, 2015. Vol. 86. November. pp. 217-221.

18. Goldsmith K. M., Byers E. S. Perceived impact of body feedback from romantic partners on young adults' body image and sexual well-being//Body Image, 2016. Vol. 17. June. pp. 161-170.

19. Herbozo S, Thompson J.K. Development and validation of the verbal commentary on physical appearance scale: Considering both positive and negative commentary// Body Image, 2006. December 3(4).pp.335-44.

20. Labunskaya V., Shkurko T. Impact of appearance components evaluation on overall satisfaction and concern with one's appearance in youth// 4th International Multidisciplinary Scientific Conference on Social Sciences and Arts SGEM 2017 (2017 г.). Conference Proceedings, 2017. Book 3. Vol 2. pp. 173-180.

21. Labunskaya V., Shkurko T. The components of appearance of a person as the tokens of his age//4th International Multidisciplinary Scientific Conference on Social Sciences and Arts SGEM 2017. Conference Proceedings, 2017, Book 3. Vol 2. Pp. 363-370.

22. Noser A., Zeigler-Hill V. Investing in the ideal: Does objectified body consciousness mediate the association between appearance contingent self-worth and appearance self-esteem in women?//Body Image, 2014. Vol. 11. Issue 2. March, pp. 119-125.

Гижсиикий В.В., Негрий В.A

\section{ОСОБЕННОСТИ ПСИХОЭМОЦИОНАЛЬНОЙ И МОТИВАЦИОННОЙ СФЕР СТУДЕНТОВ, ПРЕДРАСПОЛОЖЕННЫХ К НАУЧНОЙ ДЕЯТЕЛЬНОСТИ}

В настоящее время в период активно развивающихся технологий, и как следствие изменение образа науки и учёного в сознании людей, представляется актуальным изучение различных психологических аспектов учащихся, чья деятельность связана с наукой. В настоящее время растёт интерес молодёжи к науке, и в то же время для них открываются 
новые возможности в различных организациях и предприятиях, готовых разрушить старые стереотипы "бедной и бесперспективной" науки. В связи с этим видится актуальным изучение психологических особенностей студентов, предрасположенных к работе в науке, а также дальнейшая их поддержка.

Основной целью исследования стало выявление студентов, предрасположенных к научной деятельности, и сравнение их с другими студентами по ряду психологических характеристик (по показателям депрессии, тревоги и мотивационной сферы).

В исследовании приняло участие 73 студента физического факультета МГУ имени М.В. Ломоносова, все они прошли батарею следующих методик:

1. Опросники на выявление уровня беспокойства (тревоги): The Penn State Worry Questionnaire (PSWQ) и GAD-7.

2. Опросники на депрессию: опросник Зунга и PHQ-9.

3. Опросник учебной мотивации Т.О. Гордеевой.

4. Шкала внутренних и внешних жизненных целей (Т.Кассер, Р.Райан).

5. Незаконченные предложения.

Достижение цели по выявления психологических особенностей студентов склонных к научной деятельности включало три этапа:

1. На основании результатов, полученных по шкале внутренних и внешних целей (Т. Кассер, Р. Райан) необходимо было выявить кумулятивный показатель целей, связанных с научной деятельностью. Для решения данной задачи был произведен расчет среднего по шкалам важности научной деятельности (для студента), вероятности достижения в ней успеха и субъективной оценки студента своих достижений в науке.

2. С помощью методов описательной статистики (квартили) были выявлены студенты с высокими по кумулятивному баллу целей научной деятельности. Эту группу студентов мы обозначили как студентов предпочитающих научную деятельность (ПНД).

3. В рамках третьего этапа проводилось сравнение двух групп студентов по психологическим характеристикам с помощью t-критерия.

Сравнение по показателям на беспокойство: студенты с высокими показателями по кумулятивному баллу испытывают меньшую тревогу, чем остальные студенты (опросник the penn state worry questionnaire - значимые результаты, GAD-7 - на уровне тенденции). Студенты, предпочитающие научную деятельность, меньше, чем остальные студенты склонны испытывать и переживать чувство беспокойства и тревоги.

Сравнение по показателям на депрессию: студенты с высокими показателями по кумулятивному баллу испытывают меньше депрессивных переживаний, чем остальные студенты (PHQ - 9 - значимые результаты). По опроснику Зунга наоборот - значимых различий нет. Интересно отметить, что при качественном анализе данных, полученных опросником Зунга: самые высокие показатели имели те же студенты, что и с высокими показателями опросника PHQ-9. Можно предположить, что студенты, предпочитающие научную деятельность, меньше, чем остальные студенты склонны к депрессивным переживаниям.

Сравнение по показателям на мотивацию: студенты с высокими показателями по кумулятивному баллу имеют более высокие показатели по внутренним мотивам и идентифицированной регуляции, а также значительно ниже по экстернальной регуляции и амотивации (значимые результаты).

Ряд отечественных и зарубежных исследований показывают, что внутренние мотивы являются оптимальными учебными мотивами, выступающими предикторами высоких академических достижений, настойчивости, психологического благополучия (Deci, Ryan, 1985, 2000, 2008; Гордеева, 2013; Чирков, 1991; Vallerand, 1997 и др.). В связи с этим и исходя из полученных данных можно заключить, что студенты, предпочитающие научную деятельность, имеют более высокие показатели по внутренним мотивам в отличие от остальных студентов, а, следовательно, могут быть более успешны в академических достижениях, настойчивы и в целом психологически благополучны. Но несмотря на 
продуктивность внутренних мотивов для процесса учения, построение учебного процесса исключительно на данных мотивах невозможно.

Студенты, предпочитающие научную деятельность, в отличие от остальных студентов чаще проявляют идентифицированную регуляцию. Идентифицированная регуляция проявляется в том, что индивид принимает цели деятельности и осознает их значимость. В данном случае выполнение деятельности студентами происходит не для достижения внешних по отношению к ней целей (как при экстернальной регуляции) и не из-за требований общества (как при интроецированной регуляции), а по причине ощущения субъектом ее высокой значимости. Студент с идентифицированной регуляцией учится в ВУЗе потому, что знания и умения представляют для него высокую ценность. При этом учебный процесс может не приносить удовольствие, поскольку для учащегося важен именно результат (знания, умения).

Студенты, предпочитающие научную деятельность, меньше чем остальные студенты проявляют экстернальную регуляцию. При экстернальной регуляции внешние стимулы (оценки, награды и наказания за успеваемость) направляют и придают смысл выполнению учебных заданий и посещению университета. Вместе с тем, учащиеся не чувствуют себя автономными субъектами деятельности, так как их деятельность контролируется стимулами, заданными другими людьми. При экстернальной регуляции процесс деятельности не приносит удовольствия, сама деятельность не вызывает интерес, а осуществляется в связи с ожиданием внешних поощрений или, наоборот, санкций.

Студентам, предпочитающим научную деятельность, также не свойственна в отличии от остальных студентов возможность переживания отсутствия любой мотивации - амотивация. У данной группы студентов показатели значительно ниже.

Сравнение по шкале внутренних и внешних жизненных целей (Т.Кассер, Р.Райан): студенты, предпочитающие научную деятельность, имеют значимо более высокие результаты по шкалам: помощь людям, личностный рост, физическое здоровье, социальное признание. В целом у этих студентов показатели выше по всем пунктам. Таким образом, можно заключить, что студенты, предпочитающие научную деятельность, в большей степени, чем остальные студенты, стремятся помогать другим людям, заинтересованы в собственном развитии и личностном росте, стремятся заботиться о собственном здоровье и хотели бы получить признание в обществе.

Выводы:

Студенты, предпочитающие научную деятельность, и остальные студенты различаются по психологическим характеристикам:

1. Студенты, предпочитающие научную деятельность, меньше, чем остальные студенты склонны испытывать и переживать чувство беспокойства и тревоги.

2. Студенты, предпочитающие научную деятельность, меньше, чем остальные студенты склонны к депрессивным переживаниям.

3. Студенты, предпочитающие научную деятельность, имеют более высокие показатели по внутренним мотивам и идентифицированной регуляции, а также более низкие по экстернальной регуляции и амотивации.

4. Студенты, предпочитающие научную деятельность, имеют значимо более высокие результаты по шкалам: помощь людям, личностный рост, физическое здоровье, социальное признание.

Исходя из полученных выводов можно заключить, что студенты, предпочитающие научную деятельность, по сравнению с остальными студентами в целом более психологически благополучны. У них менее выражены показатели таких негативных переживаний как беспокойство, тревога и депрессия. Мотивационная сфера у таких студентов представлена внутренними мотивами и идентифицированной регуляциях, в то время как у остальных присутствует в большей степени - экстернальная регуляция и амотивация. Жизненные цели студентов, предпочитающих научную деятельность, связаны с помощью другим людям, личностным ростом, заботой о собственном здоровье и 
социальным признанием.

Мы надеемся, что изучение индивидуальных особенностей, способствующих к успешной научной деятельности, не только позволит работодателям найти своих талантливых умов, но и приведёт к созданию благоприятных условий и стимулирующих программ по развитию научного интереса и склонности к науке у современной молодежи.

\section{Литература}

1. Гижицкий В. В. Внутренние и внешние мотивы учебной деятельности как факторы академической успешности старшеклассников : Дис. ‥ канд.психол.наук: 19.00.07/ Гижицкий Виктор Владимирович; Московский государственный университет. - М., 2016. $200 \mathrm{c}$.

2. Гижицкий В. В., Гордеева Т. О. Мотивация самоуважения и уважения другими как факторы академических достижений и настойчивости в учебной деятельности // Психологический журнал/2016. - Т. 37, № 2. - С. 57-68.

3. Гижицкий В. В., Гордеева Т. О. Стратегии учебного поведения как медиаторы влияния мотивов на академические достижения // Ученые записки Орловского государственного университета. - 2015. - Т. 2, № 65. - С. 253-259.

4. Гордеева Т.О. Мотивация учебной деятельности школьников и студентов: структура, механизмы, условия развития : Дис. ... д-р.психол.наук: 19.00.07/ Гордеева Тамара Олеговна; Московский государственный университет. - М., 2013. - 444 с.

5. Deci E.L., Ryan R.M. Self-determination theory: A macrotheory of human motivation, development and health // Canadian Psychology, 2008b. - V. 49. - P. 182-185.

Горская Г.Б., Егорова В.С.

\section{СРЕДОВЫЕ ФАКТОРЫ ТВОРЧЕСКОЙ САМОРЕАЛИЗАЦИИ ЛИЧНОСТИ: ПРОТИВОРЕЧИЯ И РЕСУРСЫ ИХ ПРЕОДОЛЕНИЯ}

Вхождение человека во взаимодействие с окружающим миром в большинстве случаев актуализирует противоречие между требованиями среды и его возможностями [1]. Это противоречие усиливается особенностями современного общества. Оно все чаще характеризуется как транзитивное, отличающееся высоким уровнем неопределенности, стремительностью, многовекторностью и слабой предсказуемостью происходящих изменений [7], [8]. Рост вероятности трудностей включения человека в жизненный мир стал причиной обращения к средовым факторам самореализации личности.

Понимание значимости изменений жизненного мира для становления личности и успешности ее включения во взаимодействие с окружающим миром прослеживается в высказывании А.Маслоу [9] о том, что как никогда стремительное движение человеческой жизни существенно изменяет взаимодействие человека с миром, а это требует появления нового человека. Его главными отличительными чертами, по мнению А.Маслоу, является готовность и способность комфортно чувствовать себя в условиях постоянных перемен, при решении новых, не встречавшихся в предшествующем опыте задач. На значимость радикальных и стремительных перемен жизненного мира как фактора самореализации личности достаточно давно обратили внимание В.П.Зинченко и Е.Б.Моргунов [5], подчеркивая, что к резким переструктурированиям окружающего мира большинство людей может быть не готовым. Признаком понимания значимости средовых факторов для накопления и приумножения человеческого капитала является оформление макропсихологии как области психологии, предметом которой является преломление в сознании отдельных людей макросоциальных явлений, которые длительное время рассматривались скорее как сфера социологии [6].

За десятилетия, которые прошли со времени размышлений А.Маслоу о психологических факторах готовности человека к взаимодействию с современным жизненным миром, 
произошло осмысление многих аспектов проблемы. Это касается, в частности, детализации представлений о ресурсах готовности человека к жизни в постоянно изменяющихся условиях. Одним из проявлений этих изменений является появление концепций индивидуальной адаптируемости личности к условиям жизни и самореализации [13]. Она рассматривается как многокомпонентный феномен, включающий параметры ценностносмысловой сферы личности, способности и опыт, а также устойчивость к неопределенности, способность сопротивляться стрессам, креативность, готовность к взаимодействию с другими людьми, физическую подготовленность. Особым направлением анализа этого феномена является его рассмотрение применительно к профессиональной самореализации человека [12]. В контексте представляемого исследования важно то, что профессиональная адаптируемость способствует не только решению текущих задач профессионального развития, восприятию ситуации профессионального становления как не содержащего угроз безопасности, но и успешному управлению построением профессиональной карьеры в целом [12].

Важным для анализа средовых регуляторов деятельности человека является точное понимание того, какова структура социальной среды, что именно в ней воспринимается им как важное и значимое. С этой точки зрения представляется целесообразным принять во внимание характеристику психологического пространства личности, данную А.Л. Журавлевым и А.Б. Купрейченко [6]. Они рассматривают психологическое пространство личности как сформированную субъектом систему позитивно, нейтрально или негативно значимых объектов или явлений. Эти объекты и явления находятся во взаимосвязях друг с другом, выполняют определенные функции в соответствии с принятыми в социальной среде нормами и правилами.

Представление о сложной структуре психологического пространства личности вызывает необходимость в концептуальных основаниях для выделения компонентов психологического пространства и взаимосвязей между ними. К наиболее очевидным представляется в связи с этим обращение к экологическим концепциям психического развития, наиболее авторитетной из которых является концепция У.Бронфенбреннера [11]. Сделанное У.Бронфенбреннером разделение компонентов жизненной среды человека на микро-, мезо-, эко- и макросреду дает возможность обосновать направления исследования средовых факторов благополучного и конструктивного включения личности в социум. Именно с таких позиций были проведено исследования средовых факторов раскрытия личностью своих возможностей в творческой деятельности. Целью этого исследования было установление значимых средовых факторов включения художников в социальный контекст творческой самореализации и выявление необходимых для этого личностных ресурсов.

Представляемое исследование было посвящено проблеме готовности художников к творческой реализации в присущем данной сфере деятельности социальном контексте. Исходными для исследования готовности студентов - будущих художников к включению в социальный контекст творческой самореализации были следующие положения:

- профессиональная деятельность художника не связана с нормативно задаваемыми способами и критериями успешности деятельности, как в большинстве трудовых профессий;

- неотъемлемой чертой деятельности художника является противоречие между значимостью творческой индивидуальности и необходимостью принимать во внимание сложившиеся в обществе критерии профессиональной успешности;

- свойственное художникам стремление к персонализации порождает противоречие между стремлением обрести понимающую аудиторию и опасением негативных мнений и оценок со стороны окружающих, которое является причиной трудностей социальнопсихологической адаптации;

- приобретение молодыми людьми профессии художника часто не одобряется родителями, рассматривающими ее как ненадежную, не обещающую жизненного благополучия; 
- профессия художника содержит высокий риск несоответствия между вложенными усилиями на получение профессии и степенью профессиональной реализации и признания.

Перечисленные особенности профессии художника являются фактором риска эмоциональных перегрузок и развития неблагоприятных эмоциональных состояний [10].

Обусловленные спецификой профессии особенности включения художников в контекст творческой самореализации осложняются его такими современными особенностями, как сочетание снижения ограничений свободы творчества с низким уровнем социальной поддержки художников, со стремительными изменениями конъюнктуры художественного рынка. В особенностях социального контекста творческой самореализации художника просматриваются влияния всех компонентов жизненного мира современного человека, выделенных У.Бронфенбреннером от микросреды до макросреды, что подтверждается данными многих исследований [2]. В связи с перечисленными особенностями социального контекста художественного творчества возникает вопрос о том, какие из них особенно значимы для начинающих художников и какими личностными ресурсами они располагают для включения в современный социальный контекст творческой самореализации. На значимость нахождения ответов на перечисленные вопросы указывают исследователи подготовки будущих художников к профессиональной деятельности [3].

В исследовании особенности включения в социальный контекст студентов-художников профессиональной самореализации сопоставлялись с аналогичными параметрами студентовэкономистов. Их профессия отличается от профессии художников наличием социально заданных образцов и критериев профессиональной деятельности, признанием ценности профессии как ресурса материального благополучия, одобрительным отношением родителей к профессиональному выбору детей. В исследовании приняли участие студенты Краснодарского художественного училища (57 женщин и 60 мужчин) и студенты автономной некоммерческой организации высшего профессионального образования «Кубанский институт международного предпринимательства и менеджмента» (33 женщины и 45 мужчин). Возраст участников исследования составлял от 17 до 22 лет.

Результаты исследования подтвердили предположение о том, что специфика социальнопсихологических условий включения художников в контекст творческой самореализации отражается на восприятии ими социального окружения, параметрах социальнопсихологической адаптации и самоотношения. Согласно данным исследования, студентыхудожники достоверно уступают студентам - экономистам по всем параметрам социальнопсихологической адаптации, хотя и у тех, и у других показатели социально-психологической адаптации находятся в пределах нормы. Причем заслуживает внимания тот факт, что у студентов-экономистов достоверно выше, чем у художников показатели как адаптивных, так и дезадаптивных проявлений социально-психологической адаптации. Такое соотношение показателей говорит о большей активности взаимодействия с социумом студентовэкономистов, которое становится для них источником и позитивного, и негативного опыта.

Для студентов-художников характерна меньшая активность контактов с социумом при несомненной ориентации на него. Основанием для такой характеристики отношения художников к взаимодействию с социумом являются многочисленные положительные корреляционные связи показателей социально-психологической адаптации с показателем социоцентрической мотивации, с одной стороны, и положительные корреляционные связи эгоцентрической мотивации с дезадаптивными параметрами адаптации к социуму. Еще одним аргументом в пользу противоречивого отношения художников к взаимодействию с социумом является демонстрируемая художниками невысокая значимость ближайшего социального окружения, особенно, семейного, при многочисленных положительных корреляционных связях показателей значимости родителей и других членов социального окружения с параметрами мотивации учебной деятельности.

Противоречивость отношения художников к социальному окружению и взаимодействию с ним сочетается у них с критичностью отношения к себе, которое накладывает отпечаток на взаимодействие с социальным окружением. Его примером является многочисленные 
корреляционные связи показателя непринятия себя с параметрами деструктивных проявлений ответственности

В группе студентов-художников прослеживаются более ярко выраженные гендерные различия по параметрам социально-психологическо адаптации по сравнению с группой студентов-экономистов. По показателям социально-психологической адаптации мужчиныхудожники уступают девушкам. Такое соотношение показателей является отражением давления гендерного стереотипа мужественности, предполагающего успешность как его наиболее существенный признак. Культ успеха, как показывают исследования, становится источником тревоги и депрессии, снижения самооценки [24].

Полученные в исследовании данные анализировались с точки зрения того, какими ресурсами располагают будущие художники для принятия, осознания ситуации включения в процесс творческой самореализации. Согласно результатом исследования, основным ресурсом оказывается устойчивая внутренняя мотивация приобретения профессии художника. По показателям внутренней мотивации учебной деятельности художники достоверно превосходят студентов-экономистов. Следовательно, выбор профессии является осознанным личным решением художников, что обусловлено ранним включением в ее освоение. Ограничителями включения в профессиональную деятельность являются для художников чрезмерная критичность самоотношения и амбивалентное отношение к социальному окружению.

Истоки как ресурсов, так и ограничений конструктивного включения художников в контекст профессиональной самореализации в значительной степени обусловлены ранним включением в освоение профессии. Прохождение с детского возраста всех ступеней профессионального развития с высокой вероятностью выводит на уровень профессионального образования тех юных художников, которые воспринимают творческую деятельность как личностно значимую. В то же время для художественных школ, как и для других образовательных учреждений для детей, одаренных в той или иной области, характерна ситуация возникновения монокритерия межличностного сравнения, которым являются успехи в избранной сфере творческой самореализации. Последствием воздействия на становление самосознания монокритерия межличностного сравнения с высокой вероятностью оказывается высокая критичность самоотношения и снижение самооценки у тех учащихся художественных школ, которые не демонстрируют высокой степени соответствия основному критерию межличностного сравнения.

Связанное с монокритерием межличностного сравнения повышение конкуренции во взаимоотношениях вызывает недоверчивое и настороженное отношение к социальному окружению. Следовательно, с ранних этапов включения в освоение профессии художника у ее субъектов появляются психологические предпосылки, затрудняющие принятие свойственных профессии противоречий включения в социальный контекст творческой самореализации. Специалисты в области художественного образования, с одной стороны, осознают данную проблему, с другой стороны, видят ее решение в расширении компетентности студентов-художников в плане технологии ведения переговоров, оформления договоров с заказчиками и решения других задач взаимодействия с профессиональным социальным окружением. Тем самым, образовательная стратегия ведет к возникновению несоответствия между психологическим смыслом трудностей включения молодых художников в контекст творческой самореализации и средствами ее решения. Из поля зрения специалистов выпадает основное условие включения в социальный контекст творческой самореализации: личностная готовность к нему.

Современные условия амплифицируют проблемы включения художников в социальный контекст творческой самореализации, усиливая множественность детерминации закономерных противоречий этого процесса. В связи с этим становится более очевидной значимость личностных ресурсов противостояния им. Это отчетливо продемонстрировали 90-е годы прошлого столетия, когда представители многих творческих профессий столкнулись с проблемой собственной невостребованности. Далеко не всем в этих условиях 
удалось противостоять возникшим трудностям, избежать депрессии и других форм дезадаптации. Усиление миграционных процессов выявило еще один фактор, усиливающий трудности профессиональной самореализации художников: попытки найти себя не на родине, а в других странах обнаружили существенные трудности включения в непривычные социальные реалии и достижения признания в новой ситуации.

Ресурсом готовности к самореализации художников в современном социальном контексте является, прежде всего, способность осознать и принять противоречивые условия этого процесса. Это требует личностной зрелости и профессиональной психологической культуры во всех ее составляющих: когнитивных, эмоциональных, коммуникативных, регуляторных.

\section{Литература}

1. Абульханова К.А. Рубинштейновская категория субъекта и ее различные методологические значения. //Психология индивидуального и группового субъекта / Под ред. А.В. Брушлинского, М.И. Воловиковой. М.: ПЭР СЭ. 2002. С. 34 - 53.

2. Горская Г.Б., Егорова В.С. Социально-средовые ресурсы включения художника в процесс творческой самореализации. //Человек. Сообщество. Управление. 2014, № 4, с.103117.

3. Грибкова О.В., Ушакова О.Б. Значение научно-инновационной подготовки в профессиональном становлении будущих специалистов в вузе. //Искусство и образование, 2017, № 3, c.44-51.

4. Журавлев А.Л., Купрейченко А.Б. Социально-психологическое пространство самоопределяющегося субъекта: понимание, характеристики, виды./Вестник практической психологии образования. 2007. № 2(11). С. 7-13.

5. Зинченко В.П., Моргунов Е.Б. Человек развивающийся. Очерки российской психологии. М.: Тивола, 1994. 304 с.

6. Макропсихология современного российского общества. /Под ред. А.Л. Журавлева, А.В. Юревича. М.: Изд-во «Институт психологии РАН». 2009. - 352 с.

7. Марцинковская Т.Л. Транзитивное общество как психологический феномен. //Современная социальная психология: теоретические подходы и прикладные исследования. 2013. № 2. Сю5-17.

8. Марютина Т.М. Индивидуальная адаптируемость в транзитивном обществе. //Психологические исследования. 2018. Т.18. № 57. С.1.

9. Маслоу А. Новые рубежи человеческой природы. М.: Издательство «Смысл». 1999. $425 \mathrm{c}$.

10. Холмогорова А.Б., Гаранян Н.Г. Культура, эмоции и психическое здоровье. //Вопросы психологии, 1999, № 2, с.61-74.

11. Bronfenbrenner U. The ecology of human development. Cambridge, MA.: 1979, Harvard university press. $352 \mathrm{p}$.

12. Chong S.H., Leong F.T.L. Antecedents of career adaptability in strategic career management. //Journal of career assessoment, 2017. V.25. Issue 2. P.268-280.

Ployhart R.E., Bliese P.D. Individual adaptability (I-ADAPT) theory: conceptualyzing the antecedents, consequences, and measurement of individual differences in adaptability. //Advances in human performance and cognitive engineering research. 2006. V.6. P.3-39.

Деева Н.A.

\section{ПРОБЛЕМА ЖИЗНЕННОЙ УСПЕШНОСТИ В ИЗМЕНЯЮЩЕЙСЯ СОЦИОКУЛЬТУРНОЙ РЕАЛЬНОСТИ}

В последнее время в психологических исследованиях все большую актуальность приобретает проблематика изучения жизненной успешности, связанная с исследованием ее 
феноменологических особенностей и проработкой концептуальных оснований $[1 ; 3 ; 4 ; 5 ; 6]$. Популярность данного проблемного поля обусловлена рядом взаимосвязанных факторов.

Bo-nервых, интерес человечества к успеху и успешности присутствует на протяжении исторического развития общества. Как отмечают современные исследователи, основы изучения успеха и успешности человека начали оформляться уже в античной философии, где счастье человека связывалось с его реальными достижениями в какой-либо области [2;3]. Успех - это есть показатель субъектности, а успешность ее необходимый атрибут, который участвует в процессе саморегуляции. Субъект достигая успеха в чем-либо соприкасается с результатом, как с некой границей, отражаясь от которой подтверждает свое существование.

Bo-вторых, содержательное наполнение понимания успешности взаимосвязано со складывающимися социокультурными условиями и превалирующими философскими и научными парадигмами. На сегодняшний день в изучении успешности наиболее четко выделяются социально-философский, научно-психологический и практико-прагматический подходы общим основанием для которых является понимание жизненной успешности как метасистемного образования определяющего и представляющего основные ценностные ориентиры и стратегии жизни как общества, так и человека, и являющегося точкой отсчета для субъективного выбора «жизненных координат» личности [4].

$B$-mретьих, на современном этапе развития общества происходит изменение феноменологии жизненной успешности. На сегодняшний день социокультурную реальность уже привычно характеризуют такими признаками как изменчивость, противоречивость и неопределенность. Можно сказать, что мы живем в парадоксальную эпоху иллюзорного многообразия. Так, насыщенное информационное поле манифестирует человеку множество, казалось бы, открытых возможностей, предоставляет многообразие выбора в достижении успеха. Однако, такое многообразие и текучесть создает ситуацию неопределенности и иллюзорности существования. В таких условиях сложно определить координаты, найти точки отсчета для личного успеха. При этом, совершенно конкретно общество и государство делает запрос к человеку: «быть успешным», «достигать», «добиваться лучших результатов», «совершать прорывы, победы». Таким образом, обществу нужен успешный человек, но успешный в чем?

Анализ проведенных ранее исследований, а также результаты собственной работы показывают противоречивость полученных данных и разнообразие представлений о жизненной успешности у различных категорий граждан России. Приведем пример на выборке юношеского возраста. В подавляющем количестве исследований подчеркивается, что представления об успешности в юношеском возрасте характеризуются материальноэгоистической направленностью и исключением из поля успешности духовно-нравственной составляющей. То есть, успешный человек - это материально обеспеченный карьерист, с активной жизненной позицией, который ради собственной выгоды готов на все (О.В. Гребенникова 2016, Н.И. Нефедова 2003-2004, Н.Н. Седова 2016). В проведенном же нами исследовании мы получили данные другого характера (Н.А. Деева, 2017). Для респондентов, принимавших участие в исследовании жизненная успешность представляется как умение добиваться своих целей в различных сферах жизни при этом соблюдая душевный комфорт и гармонию с окружающей реальностью. В качестве составляющих жизненной успешности четко выделились три категории: ценности, жизненная позиция и личностные ресурсы. Среди ценностей в равной степени выделялись как материально-эгоистические, так и социально-альтруистические. При исследовании ценностных ориентаций абстрактного современного успешного человека, при помощи ранжирования респондентами определены такие наиболее значимые ориентиры: саморазвитие, семья и независимость. Наименее важными считаются социальный статус, престиж, получение удовлетворения от процесса. Жизненная позиция характеризуется активностью, самодостаточностью, душевным комфортом. Личностные ресурсы определяются такими качествами как владение информацией, планирование времени, прогрессивность, мобильность, коммуникабельность, 
осмысленность жизни. Как видим, представления о жизненной успешности среди представителей юношеского возраста весьма неоднородны.

Ситуация осложняется еще и тем, что человеку, как субъекту необходимо не только быть успешным в чем-то, но и сохранять свою целостность, находить оптимальные границы взаимодействия внутреннего и внешнего мира. Нужно адаптироваться, самореализовываться, «находить себя», успевать осмысливать происходящее, ставить и достигать цели.

$B$-четвертых, три предыдущих фактора актуализируют поиск подходов и концепций, которые бы наиболее продуктивно раскрывали значение жизненной успешности в общественном развитии. Так, проблема успешности приобретает новую проблематизацию, происходит наиболее глубокое осмысление ее как психологического феномена, определения ее видов, критериев и функций. Эту тенденцию можно проследить в научнопсихологических исследованиях последнего десятилетия, где особое внимание уделяется следующим аспектам: определение сущностных характеристик, концепта и предметной области жизненной успешности (Н.В. Гафарова 2015, Н.В. Головчанова 2010, Н.А. Деева 2017, С.Ю. Ключников 2003); социальные и личные представления об успехе, успешности и успешной личности (Дворецкая М.Я., Лощакова А.Б. 2016, Ю.В. Курицкая 2012, Н.В. Розенберг 2001); выявление и обоснование факторов (Т.Г. Логвинова 2016) и наиболее значимых детерминант успешности (Н.В. Головчанова 2010, С.Ю. Ключников 2003, Л.Н. Щербакова 2006). Таким образом, в современной отечественной психологии очерчивается проблема целостного и глубокого понимания жизненной успешности как интегративного образования, встроенного в систему саморегуляции.

$B$-nятых, Жизненная успешность как феномен отражает основные ценностные тенденции и устремления личности и общества и, наряду с этим, является неким субъективным регулятивом, связанным с самооценочными психологическими образованиями и во многом определяющим траекторию становления личности, в том числе в духовно-нравственном аспекте. Исходя из этого, методологической основой, позволяющей наиболее конструктивно подойти к изучению данного феномена представляется синтез регулятивного и ресурсного подходов, которые реализуют принципы субъектности и системности. Жизненная успешность понимается как интегративный метаресурс в системе саморегуляции, осуществляющий функцию рефлексивного сопоставления социальных и индивидуальных представлений о жизненной успешности с целью построения собственной жизненной программы и выступает: 1) как совокупность особых рефлексивных механизмов, функционирующих в ценностно-смысловом пространстве личности в иерархической взаимосвязи «цель-ценность-бытие» и направленных на понимание соотношения цели и результата деятельности с учетом их социальной значимости и бытийной осмысленности; 2) как интегральное свойство личности, состоящее из структурно-функциональных блоков личностных качеств, обеспечивающих направленность, волевую регуляцию, рефлексию и социально-психологическую сторону функционирования механизмов жизненной успешности; 3) как состояние, возникающее в процессе достижения цели и оценивания результата, сопровождающегося позитивным тоном, оказывающим активизирующее влияние на личность [4]. Соответственно, сформированность механизмов жизненной успешности, оформленность и содержательная наполненность как интегрального свойства и зрелость состояния определяют особенности ее функционирования как метаресурса в системе саморегуляции.

Приведем пример. Изучение механизмов жизненной успешности в юношеском возрасте позволило выявить проблему сформированности рефлексивно-аксиологического механизма, связанную с осознанием значимости для личности, выполняемой общественно значимой деятельности. Рефлексивно-аксиологический механизм раскрывается в конструировании личностью своего взаимодействия с социальной реальностью на основании ценностей как социальных и внутриличностных образований при осуществлении значимой социально оцениваемой целенаправленной активности. В этом случае происходит своего рода объединение внешнего и внутреннего миров, «движение ценностей», когда под воздействием 
социума личность оформляет и изменяет свои ценностные ориентиры, а также через свою деятельность влияет на ценностные ориентации общества, порой создает и включает ценности в социальную плоскость. Именно рефлексивно-аксиологический механизм дает возможность человеку осознать значимость своих целей, результатов, жизни, деятельности, понять, зачем он нужен в этом мире, оценить и осмыслить свой успех. Отметим, что в данном случае, масштабы деятельности, вклада в ход развития общества могут быть оценены как с позиции самого человека (сугубо субъективно), так и с позиций общества и культуры (более объективный подход). Это может проявляться в недостаточном осознании значимости своей деятельности для себя и для общества.

Таким образом, существующие проблемы жизненной успешности субъекта в изменяющейся социокультурной реальности совершенно четко оформляют запрос к психологической науке. Результаты теоретических и эмпирических исследований структурно-функциональной организации и содержания жизненной успешности современного человека могут послужить основанием для лучшего понимания саморегуляции и системы психологических ресурсов. На основании полученных данных представляется возможность построения наиболее эффективных программ личностного роста, помогающих определить человеку координаты жизненной успешности, обрести субъктность.

\section{Литература}

1. Гафарова Н.В., Черняева Ю.Е. Анализ содержания концепта "Жизненная успешность" как основа разработки исследовательской методики // Современная психодиагностика России. Преодоление кризиса. Челябинск, 2015. С. 35-39.

2. Головчанова, Н.С. Жизненная успешность как предмет психологического исследования и психологического консультирования [Текст] / Головчанова Н.С. // Вестник Ярославского государственного университета им. П.Г. Демидова, 2009, №3 (9). - С. 47-50.

3. Дворецкая М.Я., Лощакова А.Б. Образ успешности в современных психологических исследованиях // Интернет-журнал «Мир науки» 2016, Том 4, номер 2 http://mirnauki.com/PDF/09PSMN216.pdf (доступ свободный).

4. Деева Н.А. Жизненная успешность: механизм, свойство, состояние. Контексты понимания // Современные исследования социальных проблем 2017, Том 8, № 11, С. 22-45. http://ej.soc-journal.ru

5. Левченко В.В. Секреты успеха и успешности современного человека [Электронный ресурс] : монография / В.В. Левченко. - М. : ФЛИНТА, 2014. — 259 с.

6. Логвинова Т.Г. Жизненная успешность как психологический феномен // Образование и общество. 2016. Т.3. № 98. С.75-80.

Дёмин А.Н.

\section{ПСИХОЛОГИЧЕСКАЯ ГОТОВНОСТЬ К ПРЕОДОЛЕНИЮ КРЕДИТНОЙ ЗАДОЛЖЕННОСТИ*}

\section{* Исследование выполнено при финансовой поддержке РФФИ в рамках научно- исследовательского проекта № 18-013-01176}

Положение дел в области оказания и использования кредитных услуг насыщено проблемами, в том числе психологического порядка, способствует росту социальной неопределённости и формированию социальных групп с высоким уровнем финансовой напряженности и фрустрированности. Появились «регионы-лидеры» по доле просроченной задолженности среди населения (например, Кабардино-Балкарская Республика, КарачаевоЧеркесская Республика, Краснодарский край, Омская и Кемеровская области, Республика Бурятия, Ставропольский край). 
Анализ зарубежной литературы свидетельствует о том, что исследования кредитной активности населения эволюционируют в сторону понимания её как особой линии жизненного пути, которой могут быть поставлены в соответствие, с одной стороны, специфические жизненные ситуации «взятие - использование - возврат кредита», имеющие свои содержательные границы [7], с другой - обобщённые понятийные конструкции.

Одно из таких обобщённых понятий - «психологическая готовность к преодолению кредитной задолженности». В последние годы понятие готовности используется при изучении разных форм экономический активности человека: готовность к предпринимательской деятельности (С.Т. Джанерьян) и экономической самореализации (Д.А. Китова), готовность к управленческой деятельности (Е.Б. Филинкова); появились работы, посвящённые готовности к заимствованию (М.А. Гагарина) и поручительству при займах (А.Ю. Алексеева).

На наш взгляд, при обсуждении понятия «психологическая готовность» в сфере кредитнозаёмной активности недостаточно просто заимствовать общую структуру готовности, тем более что у разных авторов она варьирует по своему составу. Требуется перевод общепсихологических представлений в данную сферу жизни человека с учётом специфики этой сферы и при сохранении главной функции готовности (мобилизация и использование ресурсов на требуемом для решения задачи уровне).

Выделим четыре аспекта готовности к преодолению кредитной задолженности: «своевременность личности» (К.А. Абульханова); отношение к кредитам; отношение к труду и потреблению; характеристики социальной сети/доступность социальной поддержки.

\section{Своевременность личности.}

Согласно К.А. Абульхановой, это качество определяет меру соответствия активности личности жизненным ситуациям [1]. Оно является составной частью регуляции деятельности в объективном времени, влияет на непрерывность жизненной линии. С нашей точки зрения, конкретными формами проявления своевременности в изучаемых ситуациях выступают финансовый самоконтроль, финансовая самоэффективность, локус контроля в финансовой сфере. Они обеспечивают соотнесение желаний, планов - с одной стороны, и личностных и временных ресурсов - с другой, в конкретных обстоятельствах при принятии финансовых и потребительских решений. Такое понимание исходит из работ [5, 6, 9 и др.]. В исследованиях были выявлены интересные факты: самоконтроль (если быть точным - склонность к импульсивным покупкам как его составляющая) оказался более значимым предиктором задержек, чем финансовая грамотность; люди с выраженной импульсивностью в большей степени склонны к использованию магазинных карт, предоставляющих возможность отсрочки платежа, каталогов для заказов по почте, краткосрочных кредитов под высокий процент и т.п. Открытым остаётся вопрос о приоритетности влияния на финансовые решения общего самоконтроля и специального (т.е. в конкретной сфере жизни) самоконтроля, общей самоэффективности и специальной самоэффективности.

Структура финансового самоконтроля может включать особенности планирования расходов, финансовую выдержку, способность к детальной проработке условий принимаемых решений и др. параметры. В настоящее время данный вопрос нами прорабатывается в рамках создания соответствующего психометрического инструмента.

\section{Отношение к кредитам.}

Оно включает аффективно-мотивационный, когнитивный (осведомлённость о кредитах) и поведенческий (выбор и реализация способов совладания с кредитной задолженностью) компоненты [4]. Понятие отношения к кредитам развивает традицию В.Н. Мясищева, С.Л. Рубинштейна, рассматривавших отношение как генерализованную характеристику личности; в этом случае преодолевается широко распространённое одномерное понимание кредитных/долговых аттитюдов (позитивное или негативное отношение к займу и т.п.). В уже проведённых исследованиях установлены пять составляющих аффективно-мотивационного компонента: получение удовольствия от использования кредита; превращение мечты в реальность; настороженное отношение к кредитам; принятие кредита как нормы жизни; ориентация на целевое «крупное» использование денег. Как оказалось, настороженное 
отношение к кредитам является предиктором их своевременного возврата [3]. Ещё один компонент отношения к кредитам - выбор способа совладания с трудностями также связан с возвратом кредита. В частности, выбор избегающего поведения существенно уменьшает вероятность своевременного возврата кредита. По-видимому, сочетание этих двух факторов (настороженное отношение и избегающее поведение) принципиально важно для предсказания статуса плательщика и может использоваться при решении различных практических задач.

\section{Отношение к труду и психологическая структура занятости.}

Кредитование - это опережающее потребление, когда «товар сначала покупают, а затем уже выкупают своим трудом» [2]. Поскольку соотношение социальных процессов труда и потребления стремительно меняется, можно предположить, что отношение к труду (ценностное - инструментальное) будет одним из факторов дифференциации «должников» и «плательщиков» (т.е. своевременно выплачивающих кредит)».

Несмотря на огромное количество работ, посвящённых трудовой деятельности как таковой, мы имеем значительно меньше психологических (именно психологических, а не социальноэкономических) разработок, посвящённых социальным и психологическим функциям труда, их эволюции и взаимодействию с досугом, потреблением, отношениями собственности и т.д. Вероятно, на уровне анализа социальных и психологических функций труда могут быть получены зависимости, важные для понимания кредитно-заёмной активности. Зарубежные исследования демонстрируют связь между состоянием должников и психологической структурой трудовой занятости, рассматриваемой через призму модели М. Яходы. Это означает, что структурирование времени жизни, приобретение социального статуса и другие социопсихологические функции труда могут влиять на кредитно-заёмную активность человека.

В целом мы предполагаем, что отношение к труду (приверженность труду как ценности) и психологическая структура занятости влияют на процесс и результативность преодоления кредитной задолженности.

\section{Доступность социальной поддержки.}

В литературе накоплены результаты, свидетельствующие о роли социальной поддержки в преодолении трудных ситуаций. Выявлено, что лица с высоким уровнем ожидаемой помощи более точно и позитивно оценивают себя и других, они используют более эффективные стратегии совладания и более эффективны в межличностном плане; ожидаемую помощь можно рассматривать в качестве проявления социального оптимизма, т.е. как особую личностную характеристику [8]. Гипотетически различные параметры социальной сети и ожидаемой социальной поддержки как одного из ресурсов личности могут влиять как на решения о заимствовании денежных средств, так и на поведение, направленное на возврат займов.

Нами подучены данные, свидетельствующие о том, что отсутствие выраженного стремления разделить ответственность за выплату кредита со своими родными, близкими, коллегами и трезвая оценка своей социальной сети являются важными факторами преодоления финансовых затруднений, связанных с возвратом кредита. Аналогичные данные получены при исследовании безработных, которые смогли достаточно быстро восстановить свою занятость. Возможно, мы имеем дело с некоторой универсальной закономерностью экономической активности личности.

В заключение отметим, что обращение к понятию «психологическая готовность к преодолению кредитной задолженности», во-первых, позволяет получить теоретический инструмент для анализа кредитно-заёмной активности человека и - одновременно - для анализа личности в ситуациях возникновения и преодоления противоречий. Его преимущество - в интегральности, способности объединить частные факторы и переменные.

Во-вторых, появляется возможность объединения общепсихологического и экономикопсихологического подходов к изучению феномена готовности - важной составляющей психической активности в целом. 
В-третьих, открываются дополнительные возможности для прикладных психологических исследований и разработок на финансовых рынках, в частности, для формирования культуры финансового поведения личности. Она включает в себя не только экономическую составляющую (финансовая грамотность, о повышении которой сейчас много говорят), но и психологическую составляющую, которая обеспечивает понимание рисков и возможностей своей модели поведения.

\section{Литература}

1. Абульханова К.А. Личность как субъект жизненного пути // Время как фактор изменений личности. Минск: ЕГУ, 2003. С. 24-65.

2. Бодрийяр Ж. Система вещей. М.: Рудомино, 2001.

3. Дёмин А.Н., Киреева О.В. Психологические факторы возврата кредита // Вопросы психологии. 2018. № 3.

4. Дёмин А.Н., Киреева О.В., Педанова Е. Ю. Разработка опросника отношения к кредитам и его психометрическое обоснование // Человек. Сообщество. Управление. Краснодар. 2016. Т. 17. №4. С. 153-166.

5. AchtzigerA., Hubert M., Kenning P., Raab R., Reisch L. Debt out of control: The links between self-control, compulsive buying, and real debts // Journal of Economic Psychology. 2015. V. 49. P. 141-149.

6. Gathergood J. Self-control, financial literacy and consumer over-indebtedness // Journal of Economic Psychology. 2012. V. 33(3). P. 590-602.

7. Kamleitner B., Hoelzl E., Kirchler E. Credit use: Psychological perspectives on a multifaceted phenomenon // International Journal of Psychology. 2012. V. 47(1). P. 1-27.

8. Pierce G.R., Sarason I.G., Sarason B.R. Coping and social support // Handbook of coping: theory, research, applications / Ed. by M. Zeidner and N.S. Endler. N.Y.: John Wiley \& Sons, 1996. P. 434-451.

9. Webley P., Nyhus E. K. Life-cycle and dispositional routes into problem debt // British Journal of Psychology. 2001. V. 92(3). P. 423-446.

Дёмин А.Н., Киреева О.В., Педанова Е.Ю.

\section{ЭМПИРИЧЕСКИЕ ПРЕДПОСЫЛКИ РАЗРАБОТКИ ОПРОСНИКА «ФИНАНСОВЫЙ САМОКОНТРОЛЬ ЛИЧНОСТИ»*}

\section{* Исследование выполнено при финансовой поддержке отделения гуманитарных и общественных наук РФФИ в рамках научно-исследовательского проекта № 18-013-01176 А.}

Проблема финансового самоконтроля в настоящее время является одним из распространенных запросов в психологическом консультировании. Способность личности осознанно подходить к выбору и реализации разнообразных форм финансового поведения (таких, как кредитование и возврат долга, накопление и сбережение, инвестирование, расходование денежных средств и т.п.) является одним из значимых качеств зрелой личности [2]. В условиях экономической нестабильности данный ресурс личности приобретает особое значение: выбранные личностью финансовые стратегии отражаются на возможностях самореализации в различных сферах жизнедеятельности.

В рамках психологических исследований изучается роль самоконтроля при реализации финансовой активности и подчеркивается его регулирующая роль. Традиционно финансовый самоконтроль исследователи связывают с негативными последствиями потребительского поведения, в том числе с возникновением проблемной задолженности (Gathergood, 2012; Achtziger et al., 2015). 
Теоретический анализ показал, что финансовый самоконтроль представляет собой часть системы саморегуляции личностью финансового поведения, которая связана с управлением результативностью и оптимальностью реализации замысла активности. Согласно подходу О.А.Конопкина, самоконтроль выступает как регуляторное звено, реализующее оценку текущих и конечных результатов относительно системы принятых субъектом критериев успеха, предоставляющим информацию о степени соответствия между запрограммированным ходом деятельности, ее этапными и конечными результатами и реальным ходом их достижения [3]. В работах зарубежных авторов выделяется такие основные проявления самоконтроля, как приверженность цели, способность не откликаться на соблазны, консистентность планирования (Webley, Nyhus, 2008).

Можно выделить несколько существенных составляющих, отражающих наличие у личности самоконтроля:

- постановка цели в соответствие со специфическим замыслом, идеей деятельности,

- готовность соответствовать этому замыслу, предполагающая уверенность в правильности цели и необходимости ее достичь, наличие и отчетливость приоритетности данной цели, по сравнению с другими целями,

- знание факторов результативности и оптимальности (ресурсов и условий) и способность видеть свои ресурсы,

- видение возможных этапов, динамики и возможной вариативности развития ситуации (включенность цели в более широкий жизненный контекст),

- усилия, направленные на соподчинение потребностей и перераспределение ресурсов в соответствии с замыслом.

Полагаем, что феномен самоконтроля личности является многомерным явлением, содержащим процессуальный и регуляторно-личностный компоненты. Он включает способность индивида управлять своим поведением и эмоциями, обдуманно реагировать на происходящие события и прерывать действия, обусловленные нежелательными импульсами и эмоциями [1].

Обобщая подходы к трактовке феномена самоконтроля и делая акцент на специфике финансовой ситуации, сформулируем следующее определение понятия «финансовый самоконтроль»: способность индивида управлять своим финансовым поведением и эмоциями в ситуации потребления, инвестирования, займа и сбережения денежных средств, обдуманно реагировать на происходящие события в ситуации финансового поведения и прерывать действия потребления, инвестирования, займа и сбережения денежных средств, обусловленные нежелательными импульсами и эмоциями [2]. Следовательно, в нашем исследовании подчеркивается, что финансовый самоконтроль проявляется как в потребительском поведении, так и в кредитно-заёмной и сберегательной активности человека.

В данной статье рассмотрим эмпирические индикаторы, которые составят основу опросника, измеряющего финансовый самоконтроль.

Для выявления показателей финансового самоконтроля использовались данные полуструктурированных интервью с заемщиками, которые не смогли вовремя вернуть долг по кредиту, демонстрируя при этом разное отношение к займам, разные формы и способы преодоления возникших затруднений.

На основе проведенного контент-анализа полученных с помощью интервью данных в структуру финансового самоконтроля были включены следующие компоненты:

- Планирование расходов.

Так, респондент 12 указывал, что «(трудности) Изредка бывают, но я надеюсь еще наладить всё. А справляюсь сам, пару раз шабашил, чтобы деньгами разжиться и продолжать развивать бизнес.... Вот как раз планирую взять кредит побольше, чтобы этот закрыть и остальные деньги вложить в работу». 
В отличие от него, респондент 17 указывал на наличие трудностей в планировании расходов: «... Не привык я, что рассчитывать на всю зарплату нельзя. Денег теперь еще больше не хватает...».

Другая опрошенная (респондент 18) демонстрировала сложности с прогнозированием финансовой ситуации: «Должна признаться, не так хорошо, как я планировала. Бизнес приносит доход, но не стабильный, поэтому иногда с выплатой возникают сложности... Это мы как-то не предусмотрели».

Показатели уровня выраженности способности распределять расходы отражены в ответах респондента 33: «Всё время находятся проблемы. То туда деньги нужны, то сюда. А надо ещё и на выплату кредита отложить. Это не первый раз, когда я беру кредит. В прошлый раз было ещё хуже, чем сейчас. Боялась, что всё повторится. Пришлось в тот раз даже машину продать, чтобы выплатить... Сложности есть, потому что деньги не всегда есть. Занимала у знакомых, чтобы взнос делать в срок...».

В ответах респондентов обращает на себя внимание то, что заемщики, пытаясь решить свои финансовые проблемы с помощью кредитных средств, сталкиваются с новыми трудностями, связанными с необходимостью учитывать и распределять расходы не только на нужды своей семьи, но на выплату долга по кредиту. Самоконтроль в данном случае позволяет планировать и регулировать распределение расходов.

- Захваченность процессом покупок.

Респондент 16 ярко демонстрирует данные особенности в поведении: «Потому что мечту исполнить решила. Всю жизнь о сережках мечтала с алмазами и сапфирами. А денег не хватало. Проснулась с мыслью о том, что вот хочу. Пошла да сделала.... Это (кредит) как-то даже в плане финансов себя дисциплинировать помогло».

В данном случае у испытуемого фиксируется низкий уровень самоконтроля в сфере потребительского поведения, что приводит к импульсивным тратам и к долговому поведению.

- Финансовая выдержка.

В ответах респондента 22 этот компонент финансового самоконтроля наглядно показан: «...зарплаты на всё стало не хватать. Пришлось сильно урезать траты, так и справляюсь... Поездка была прекрасной, но теперь с этими выплатами много мороки». Подобная ситуация присутствует и в ответах респондента 33: «Помня о том времени сложно брать новый, но очень хотелось всё-таки поехать в отпуск за город. Меня все ещё и отговаривали, мать даже пыталась мне запретить брать кредит. Но в первый день отпуска я всё же сделала это... Сложность одна, и это нехватка денег. Но я с этим смирилась и стараюсь жить по средствам... Стараюсь чаще вспоминать поездку и не думать о сложностях».

- Готовность к сбережениям демонстрируют следующие ответы: «Сначала проходило хорошо, я выплачивала понемногу, но меньше, чем нужно. Я ведь делала вклад, но проценты всё равно набежали. ... Сложности начались тогда, когда проценты набежали. До этого все отлично было. Теперь вот продаю квартиру и машины, чтобы рассчитаться с долгами и к маме перееду». Самоконтроль помогает личности создавать ресурсную базу.

- Когнитивная проработка финансовых решений. В ответах другого респондента также говорится: «На самом деле сложно было решить все-таки брать или не брать. Отец и муж против были, хотели, чтобы скопили сначала, а потом уже покупали машину. А цены то на них растут быстро, в отличие от зарплат, как тут скопишь? Пугали тем, что, пытаясь отдать кредит, потом и машину продать придется, и полдома. Зря пугали, к слову. Да, этот год был ужасен, но не на столько». Видно, что данный компонент самоконтроля позволяет на этапе вхождения на рынок кредитных услуг принимать решения и исполнять их, несмотря на возникающие трудности.

Таким образом, выделенные эмпирические индикаторы продолжают цикл исследований финансовой активности. Представленные в статье компоненты финансового самоконтроля будут приняты за основу для формирования шкал и суждений при разработке опросника для измерения финансового самоконтроля личности. 


\section{Литература}

1. Гордеева Т.О., Осин Е.Н., Сучков Д.Д., Иванова Т.Ю., Сычев О.А., Бобров В.В. Самоконтроль как ресурс личности: диагностика и связи с успешностью, настойчивостью и благополучием // Культурно-историческая психология. - 2016. - Т. 12. № 2. - С. 46-58. doi:10.17759/chp.2016120205.

2. Киреева О. В., Дёмин А. Н. Финансовый самоконтроль как предпосылка эффективного финансового поведения // Актуальные проблемы реализации социального, профессионального и личностного ресурсов человека. Материалы VI Всероссийской научнопрактической конференции с международным участием, посвященной 15-летию кафедры социальной работы, психологии и педагогики высшего образования Факультета управления и психологии КубГУ / под ред. Е. В. Харитоновой. - Краснодар: КубГУ, Парабеллум, 2018. С. $66-69$.

3. Конопкин О.А. Психическая саморегуляция произвольной активности человека (структурно-функциональный аспект) // Вопросы психологии. - 1995. - №1. - С. 5-12.

Ермолова В.O.

\section{ГЕНДЕРНАЯ ИДЕНТИЧНОСТЬ ПОДРОСТКА В УСЛОВИЯХ ВИРТУАЛИЗАЦИИ БЫТИЯ}

Научная рефлексия современных реалий информационной глобализации общества и такого ключевого социального явления как виртуализация бытия сегодня становиться центром изучения всех социальных наук. В условиях прогрессирующей виртуализации бытия, многие процессы развития и становления личности проходят под влиянием явлений, происходящих в виртуальном мире, то есть в сфере интернет-коммуникаций. Одним из центральных вопросов является изучение особенностей процесса идентичности личности в этих условиях. В центре нашего внимания, прежде всего, личностный аспект этого вопроса, а именно исследование новых методов интернет-коммуникации, восприятие субъектом способов коммуникации, изучение механизмов этого вида общения и изменений, происходящих с субъектом в результате такого рода коммуникаций.

Рассматривая в качестве субъекта изучения личность подростка, мы отмечаем тот факт, что именно современное поколение подростков впервые проходит все этапы развития своей личности в условиях быстроменяющейся социокультурной реальности, где многие аспекты бытия переходят в виртуальную реальность. Являясь активным пользователем интернет-коммуникаций, подросток сам становиться центром преобразования своего виртуального бытия. В глобальном понимании, это все приводит к тому, что современные тенденции в поле интернет-коммуникаций приходят и уходят стихийно, оставаясь для исследователей не предсказуемым, и их последствия становятся главным интересом для научного изучения. Одна из таких тенденций - это появление и популяризация в поле интернет-коммуникаций проблемы гендерной идентичности подростка.

Возможности, которые открывают для подростка коммуникации в интернете, безграничны, они позволяют пользователю создавать «виртуальное Я», то «Я», которое может частично или полностью отличаться от реального «Я». Экспериментируя со своей самопрезентацией на различных коммуникативных площадках, пользователь может легко подменивать как индикаторы своего внешнего облика, возраста, статуса, этнической принадлежности, так и индикаторы пола. Максимальное количество вариантов для самовыражения, начиная от себя реального, до экспериментов с кардинальным самоизменением, приводят подростка в состояние некой неопределенности и потери своего реального «Я». Даже такой очевидный реальный аспект социальной категоризации как половая принадлежность, становится под вопросом и возникает проблема гендерной идентичности подростка. 
Для рассмотрения данной проблемы стоит выделить несколько характерных черт интернет-коммуникации:

- виртуальная самопрезентация личности носит, как правило, компенсаторный характер, являясь реализацией своего идеального «Я», построенного под влиянием современных интернет-тенденций, которые задают, в том числе гендерные образцы поведения;

- анонимность, которая позволяет, уйти от персонального уровня личностной идентификации к общему, социальному уровню, проявляя во внешнем поведении при этом максимальную ориентированность и зависимость от социального одобрения;

- интернет-площадки выступают в качестве искусственной среды общения, отличительными чертами которых можно выделить размытые нечеткие и редуцированные образы субъектов общения, которые зачастую не являются отражением их реального «Я»;

- в результате индивидуально-личностного обмена социальными ролями в виртуальной среде и потребности в максимально креативной самопрезентации, у подростков зачастую стирается реальность гендерной самопрезентации, происходит потеря социальных ориентиров, строится иллюзорная реальность обретения навыков построения социальных отношений и личной индентичности.

На сегодняшний день по данным лечебно-профилактического центра Tavistock and Portman NHS Foundation Trust в Лондоне, более 1500 детей ежегодно обращаются к специалистам за помощью в определении своей гендерной принадлежности. Также отмечается рост числа детей, обратившихся в центр, и приводится статистика, согласно которой наблюдается диспропорция между числом девочек и мальчиков, число первых становится практически в 2 раза больше.[2] Доктор центра Бернадет Рен отмечает, что раннее при открытии центра подростки, родившиеся мальчиками, чаще обращались с проблемой гендерной идентичности, нежели подростки, родившиеся девочками. Это объясняется тем, что внешний вид девочек, которые выглядят по-мальчишески, является социально приемлемым. Но сейчас мировой социум становится более толерантным и к тем, и к другим.

Усугубляет проблему определения гендерной принадлежности подростка, развитие его в условиях информационной глобализации, информационной свободы и толерантности, а также популяризации в поле интернет-коммуникаций личностей с девиантным поведением.

C 2016 года отслеживается тенденция, пропагандируемая в интернет-среде, трансгендерный переход, то есть смену пола человека на противоположный. Причем в авангарде модного явления все чаще выступают дети и подростки, изъявляющие желание «поменять тело». Несмотря на то, что врачи-педиатры называют это опасным отклонением от нормы, приводящим к увеличению суицида, и бьют тревогу, в массовой интернеткультуре и западных медиа идет агрессивный пиар трансгендеров. В некоторых штатах США их право на «другое тело» и вовсе по закону может сделать любой ребенок, начиная с 15 лет.

В марте 2016 американская коллегия педиатров выпустила обращение под громким названием «гендерная идеология», в котором несколько сотен врачей призывает законодательную власть отменить нормы, позволяющие детям менять пол. Педиатры утверждают, что узаконенное отклонение приводит к массовым нарушениям психики детей.

На сегодняшний день трансгендерность рассматривается как психологическое расстройство, поскольку с биологической точки зрения «изменить пол невозможно». Это подтверждает и большинство исследований, посвящённых поведению подростков. 80\% детей, идентифицирующих себя с противоположным полом, на самом деле находятся на определённой стадии развития. Это не является гендерной дисфорией, но этапом становления личности, который довольно быстро заканчивается.

Тем не менее, в действительности существуют некие отклонения от нормы, которые в последние несколько лет участились в несколько раз. Виной тому постоянное раздувание 
проблемы в интернет-среде, а также пропаганда трансгендерности, проникшая в массовую культуру.

По данным центра медицины в Канаде, если в 2009-2010 году только 19 подростков хотели сменить пол, то в 2018 году эта цифра достигла 87 человек. При этом в 20 случаях возраст детей не превышал 4 лет.

После рассмотрения статистики возникает вопрос о причинах такого роста. Ответ прост - пропаганда трансгендерности в интернет-культуре.

Журналисты издания National Geographic побывали в восьми странах и выслушали истории 800 детей в возрасте до 10 лет, испытывающих трудности с гендерной идентификацией на фоне всеобщей вовлеченности в интернет-коммуникации.

В настоящее время выделяют несколько подходов, в рамках которых анализируется гендер в практиках конструирования виртуальной идентичности [4]:

- дискурсивный, когда гендер воспринимается по тому, как он конструируется из текстов и речи. С другой стороны, гендер сам по себе является социально конструируемым концептом - системой социальных смыслов, которые структурируют и предопределяют то, как мы смотрим на окружающий нас мир и воспринимаем его;

- этнометодологический, при котором первостепенное внимание уделяется тому, какие способы используют члены речевого сообщества, чтобы именно гендер структурировал их взаимодействие и был неотъемлемой частью окружающей их жизни;

- перформативный, когда гендер рассматривается как результат или следствие многократных перформативных действий, осуществляемых в рамках определенного культурного контекста. По мнению Т. В. Барчуновой, важным аспектом перформативной теории гендера является стремление объяснить, как происходит изменение идентичности, при котором идентичность понимается как практика означивания [1, с. 145];

- теория гендерных субкультур, которая применяется при изучении особенностей мужского и женского коммуникативных стилей, а также при анализе презентационных практик и виртуальной идентичности (словообразование псевдонимов в чатах, блогах, изучение лингвистического дизайна персональных веб-страниц и пр.);

- киберфеминизм, актуализирующий такие базовые понятия для всей гендерной теории, как виртуальный гендер, виртуальная идентичность, кибер-насилие и пр. В связи с этим пересматриваются и приобретают дополнительные смыслы базовые термины гендерных исследований: мужественность, женственность, гендерный стереотип, гендерная роль и гендерная идентичность. Е. И. Горошко указывает на то, что безусловным отличием киберфеминизма от феминизма является предлагаемая им чрезвычайно расширенная палитра выборов женских самоидентификационных и презентационных практик [5, с. 364].

Ю. В. Епанова в качестве важных следствий применения идей перформативной теории гендера Дж. Батлер при исследовании виртуальной идентичности видит два момента. Во-первых, снимается проблема истинности или ложности интернет-репрезентаций личности, поскольку вне этих репрезентаций идентичность просто не существует: мы есть только то, что мы репрезентируем. Во-вторых, подобный механизм является универсальным, а не ограничивается виртуальным пространством, что позволяет преодолевать рамки «своеобразной традиции экзотизации, весьма распространенной в рассуждениях как об Интернет в целом, так и об Интернет-репрезентациях личности в целом» [8, с. 91].

Онлайн-сообщества позволяют подросткам в безопасной среде исследовать собственную личность, завязывать отношения и делиться своими чувствами.

Результаты пилотного исследования можно изложить в четырех пунктах.

1. Социальная сеть действительно представляет собой площадку для управления впечатлением других, разыгрывания перформанса, в том числе и гендерного, которое возможно лишь с помощью таких ресурсов или системы социальных значений сайта, как коммуникация, использование фотографий, возможность комментирования и оценивания, а индивидуальные настройки приватности, создание границ для аудитории подчеркивают 
тождественность данных практик границам выбранной системы социальной сети, что верифицирует сформулированное определение виртуальной идентичности.

2. В каждом случае конструирования гендерной идентичности на сайте и использования гендерных маркеров своей страницы точкой отсчета подростков были их представления и убеждения о современных гендерных стереотипах и ролях, о соответствующих их гендеру ожиданиях со стороны других пользователей и т. п., что подтверждает сформулированное определение виртуальной гендерной идентичности.

3. Благодаря различным опциям сайта подростки заявляют о себе как о разностороннем человеке, указывая различные направления своей деятельности, начиная от ученика, спортсмена и музыканта, заканчивая описанием себя как сторонника определенного политического устройства или религии. Но в каждом случае юноши и девушки конструируют такой образ, который будет интересен и желателен подразумеваемой аудитории, одобряем ею. Конечно, встречаются исключения, но они лишь подтверждают общее правило.

4. Поскольку виртуальная гендерная идентичность социально желательна, логично предположить, что и самопрезентация на страницах сайта будет иметь традиционно гендерную коннотацию. Однако данное утверждение характерно лишь для особенностей композиции аватаров и выбора онлайн-сообществ, которые действительно имеют гендерную специфику. Следовательно, способами выражения собственной гендерной идентичности подростков в социальной сети стали наиболее наблюдаемые опции сайта: 1) аватары и возникающее одобрение противоположности мужских и женских символических значений презентации как следствие наблюдения за гендерными особенностями композиции главных фотографий профилей; 2) подписки на публичные страницы и онлайн-сообщества. Вопреки значимости для подростков личной информации на сайте, цитат, стены и статусов данные мультимедийные функции социальной сети практически не имеют ключевого значения при выражении собственной гендерной идентичности.

Согласно недавнему масштабному исследованию подростков, большинству испытуемых из мальчиков (88\%) и девочек (75\%) свойственны в равной степени признаки как маскулинности, так и фемининности, что указывает на принадлежность к андрогиннам. Андрогиния понимается как эмансипация обоих полов, интеграция женского эмоционально экспрессивного стиля с мужским инструментальным стилем деятельности. Преобладание андрогинии в наших группах испытуемых характеризуется тем, что в подростковом возрасте выстраивается собственная картина мир, свой новый образ Я и поэтому подросток не ограничивается пассивным усвоением гендерных норм и ролей, а стремится самостоятельно осмыслить и формировать свою гендерную идентичность. Андрогинность весьма благоприятна для успешной социализации личности. Индивиды обладающие одновременно маскулинными и фемининными чертами при адекватном половом самосознании и отчетливой половой идентичности позволяют себе менее жестко придерживаться полоролевым нормам, быть свободными от социальных стереотипов, свободнее переходить от традиционного женских занятий к мужским и наоборот.

У 12\% испытуемых из мальчиков выявлено преобладание маскулинности над фемининностью. Таким старшим подросткам мальчикам свойственно идентифицировать себя с маскулинными чертами, приписывать себе чисто мужские качества, такие как храбрость, властность, враждебность, агрессивность и т.д. У 20\% испытуемых девочек явно наблюдается преобладание фемининности над маскулинностью. Таким старшим подросткам девочкам свойственно приписывать себе женские черты такие как: чувствительность, нежность, конформность, эмоциональность и т.д.

Таким образом, полученные результаты, возможно объяснить тем, что существовавшие ранее традиционные образцы мужественности и женственности в современных условиях во многом изменились и продолжают меняться. Это создает серьезные трудности для подростка, пытающегося интегрировать в личности различные социальные роли, образцы поведения и черты. Подросток, выстраивая собственную картину 
мира, свой новый образ «Я», не ограничивается пассивным усвоением гендерных норм и ролей, а стремится самостоятельно и активно осмысливать и формировать свою гендерную идентичность.

\section{Литература}

1. Барчунова Т. В. Перформативная концепция гендера // Слов. гендерных терминов. М.: Информация XXI век, 2002. 256 с.

2. Батлер Дж. Гендерное беспокойство // Антология гендерной теории. Минск: Пропилеи, 2000. Гл. 1 : Субъекты пола/гендера/желания. С. 297-347.

3. Белинская Е. П. Интернет и идентификационные структуры личности. URL: http://cyberpsy.ru/2011/02/belinskaya-e-p-internet-i-identifikacionnye-struktury-lichnosti/ _ (дата обращения: 13.08.2012).

4. Горошко Е. И. Интернет-коммуникации в гендерном измерении // Вестн. Пермского ун-та. Пермь, 2006. Вып. 3: Язык - культура - цивилизация. С. 219-229.

5. Горошко Е. И. Информационно-коммуникативное общество в гендерном измерении. Харьков: ФЛП Либуркина Л. М., 2009. 816 с.

6. Горошко Е. И. Коммуникативная виртуальная идентичность: гендерный анализ // Филол. заметки / Пермский гос. ун-т. Пермь; Скопье; Любляна; Загреб, 2009. Вып. 7, ч. 2. С. 93-105.

7. Гофман И. Представление себя другим в повседневной жизни. М.: КАНОН-прессЦ : Кучково поле, 2000. 304 с.

8. Епанова Ю. В. Интернет-репрезентация идентичности в контексте перформативной теории Дж. Батлер // Вестн. СамГУ. 2009. № 1. С. 87-92.

9. Жичкина А. Е. Взаимосвязь идентичности и поведения в Интернете пользователей юношеского возраста: дис. ... канд. психол. наук. М., 2001. 199 с. $224 \mathrm{c}$.

10. Кузнецова Ю.М., Чудова Н. В. Психология жителей Интернета. -М. : ЛКИ, 2008.

11. Мид Дж. Интернализованные другие и самость // Американская социологическая мысль: тексты / под ред. В. И. Добренькова.- М.: Междунар. ун-т бизнеса и управления, 1996. C. $222-224$.

12. Митина О. В., Войскунский А. Е. Интернет в гендерном измерении // Введение в гендерные исследования. -М.: Аспект-Пресс, 2005. С. 204-216

13. Парсонс Т. Аналитический подход к теории социальной стратификации // O структуре социального действия. -М.: Академ. проект, 2000. С. 280-310.

14. Черняева К. О. Культурная идентификация в условиях глобализации: случай социальных сетей: дис. ... канд. социол. наук. Саратов, 2010. 141 с.

15. Шютц А. Основной аргумент «Идей II» Гуссерля // Смысловая структура повседневного мира. -М.: Обществ. мнение, 2003. С. 10-34.

Кара Ж.Ю.

\section{ЛИЧНОСТЬ В ЭПОХУ ВИРТУАЛЬНОЙ РЕАЛЬНОСТИ}

Мир вокруг нас меняется. Это вообще постоянно подвижная константа. Но... Современный мир стремительно меняется. И это ощутимо и заметно как никогда. Ни в какие другие периоды человечества не было так видно этих изменений.

Сегодня прогресс достиг действительно небывалых высот, а новое поколение способно использовать такие возможности, о которых еще 10-15 лет назад люди лишь мечтали. То, что было мистикой и волшебством, сегодня стало техническим прогрессом, реальностью нас окружающей.

К одним из самых значимых феноменов эпохи можно отнести виртуализацию всех сфер человека и общества. В свете происходящих в социуме изменений чрезвычайно актуальным 
представляется осмысление виртуальной реальности как глобального и универсального феномена. Эта проблема требует междисциплинарного исследования, так как затрагивает все области жизни человека, а так же социальные, образовательные, культурные, технические и др. процессы. Анализ феномена виртуальности требует оригинальных, новых подходов и меняет онтологические представления (классические, неклассические) о мире, о реальности, о способах существования пространственно-временных объектов. Согласие с тем, что есть виртуальный мир предполагает и принятие новой научной парадигмы, а именно постнеклассической, определяющей объектами своего рассмотрения нелинейность, нестабильность, индетерминированность, поливариантность, полионтичность как неотъемлемые характеристики бытия. Отличительной чертой XX в. под воздействием информационных технологий выступило формирование принципиально иной социокультурной среды, получившей название информационного общества. Специфика информационного общества выражается в том, что компьютеризация обеспечивает любому человеку широкий доступ к разнообразным источникам информации. Согласно определению социолога Д.Белла, информационное общество характеризует специфику постиндустриальной стадии развития человечества, при которой основой определения социальной структуры становится информация и, в особенности, доступ к ней.

Но, возникает вопрос, развитие новых технологий не заменит ли человека вообще. Или изменит его до неузнаваемости. Или мир и реальность будут другими. [1]

Трансформация общества в информатизационное в значительной мере влияет на изменения происходящие в новых поколениях. Размывание границ между реальностями стало характерной чертой формирования мировоззрения детей практически с раннего детства. И ребенок погружается в этот придуманный мир, в котором привычнее, спокойнее, прогнозируемо. Виртуальная реальность, есть искусственная реальность, создаваемая человеком техническими средствами. Находясь внутри этой реальности человек, самоопределяется, встраивается в новый мир, примеряя другой образ себя.

Если рассматривать с позиции аддикции, то вымышленный мир таит в себе опасность захвата над разумом. Современные условия жизни, развитие науки, в частности психологии, в постнеклассицизме указывают на центрацию такого аспекта как саморазвитие (самоорганизующиеся системы). В тоже время есть два ключевых направления в развитии науки - динамический анализ развития психологии (саморазвитие) и системное переопределение науки. Выход на иной системный уровень развития науки позволяет преодолеть существующие противоречия, в рамках одной системы, продолжая развивать тему человека как предмета психологической науки.

Родоначальник отечественной «виртуалистики» психолог Н.А.Носов придерживается мнения о существовании «многоуровневой» реальности и рассматривает ее в контексте полионтичной парадигмы. Выход на первое место значимости спонтанных, единичных, развивающихся явлений указывает на значимость виртуального во многих сферах жизни, и оно становится сопоставимым по своей значимости с константным. Соответственно значимость виртуального и константного в мире изменилась. «В обозримом будущем мир в целом и каждый его фрагмент будет все более виртуализироваться, т.е. будет происходить повышение значимости виртуальности. Виртуалистика - новое мировоззрение, соответствующее наступающей эпохе цивилизации, причем не только западной или восточной, но и любой из существующих на Земле». [2]

Появление нового подхода в постнеклассической парадигме приводит нас к новому новому типу и подходов в науке и новых практик. Понятие «многомерный мир человека» («многомерное пространство жизни») является одним из центральных в методологии системной психологии. Приняв, стоящую за этим понятием психологическую реальность, мы получаем выход к таким характеристикам сознания, как хронотопичность, дальнодействие, континуальность, оставляя психологическую мысль замкнутой в пределах абсолютно аморфной «сферы сознания», «псевдотопологической» по определению. [3] 
Последовательность восхождения сознания на более высокие уровни системной организации совпадает с этапами становления многомерного мира человека в рамках системной психологии. Движущим механизмом «человекообразования» выступает взаимодействие человека со «значимыми другими», с культурой, с организацией пространства жизни, имеющее собственные смысловые и ценностные измерения (являющимися результатом проекции в мир человеческих ожиданий, потребностей и возможностей).

Обозначим некоторые направления проводимых исследований отражающие общую тенденцию изучения психологических особенностей личности в эпоху виртуальной реальности. Конечно, развитие виртуального мира имеет положительный аспект. Использование технологий виртуальной реальности в разных областях психологии свидетельствуют о возможности высокой эффективности и в некоторых случаях преимуществом перед традиционными методами. Возможно использование виртуальной реальности для формирования установок, коммуникативных навыков. Ученые приводят данные исследований влияния обучающих и коррекционных ВР-технологий на личностное функционирование и развитие, показывают возможность применения коррекционных и развивающих ВР-программ в системе непрерывного образования. [3] В другом исследовании, применение обучающих, коррекционных, дидактических программ в виртуальной реальности оказывает влияние на модификацию функциональных личностных черт, интеллектуальных способностей, когнитивного стиля личности (В.В. Селиванов, Л.Н. Селиванова). [4]

Но, в то же время, изучая влияние виртуальной реальности на личность, отметим, что практическая всеобщая доступность технических средств, интернета несет в себе и большую проблему. Любой человек может создать свою собственную виртуальную реальность и полностью в нее погрузиться, нервничать из-за вынужденного выхода из неё, как можно реже покидать свой нереальный мир. Так в исследовании Н.В. Коптевой указывается на изучение общих чувств бытия при разной интернет-зависимости. Объясняется тот факт, что с ростом симптоматики интернет-зависимости происходит снижение проявления онтологической уверенности на уровне собственного воплощенного Я (переживание личностной автономии и связь с миром и другими); снижение уверенности в собственном теле по сравнению с Я-виртуальным (раскол целостного Я); нарушение границ между Я и неЯ как основными «составляющими» бытия-в-мире; увеличивается проявления ложного Я (неуверенность). Исследователь отмечает симптоматику зависимости, проявляющуюся в неполном объеме, в приверженности виртуальной интернет-реальности имеющей компульсивный, вынужденный характер. Другой особенностью зависимости, проявляющуюся в неполном объеме, можно указать полный уход в мир, сконструированный им самим (свобода в не свободе). [6]

Интернет-пользователи, склонные к интернет-зависимому поведению, могут характеризоваться сниженным уровнем уверенности в себе, повышенным уровнем тревожности, фрустрации, ригидности, вспыльчивостью, эмоциональной неустойчивостью, раздражительностью. Проявляется существенная личностная деформация и значительные изменения иерархии ценностей человека и как следствие, уход к иллюзорно компенсаторной деятельности, наблюдаются повышенные риски развития наркотической, алкогольной и других видов аддикций. следует отметить, что при Интернет-аддикции сам компьютер или гаджет уходит на второй план и выступает связующим звеном между пользователем и Интернетом. Интернет - это один из многих аддиктивных агентов, который при определенных обстоятельствах может быть заменен на другой. Для интернет-аддикции характерны следующие составляющие: 1) чрезмерное использование Интернета, часто - с потерей чувства времени или пренебрежением базовыми потребностями, 2) синдром отмены, включая злость, напряжение и/или депрессию, когда компьютер недоступен, 3) толерантность, включая потребность в лучшем компьютерном оборудовании, большем количестве компьютерных программ, увеличении периода времени, проводимого за 
компьютером и 4) негативные последствия, включая споры, ложь, проблемы с учебой и отдыхом, социальную изоляцию и утомление. [7]

В других исследованиях, в частности на информационном портале о профилактике и лечении аддикции «Интернет-зависимость», наблюдается в процентном соотношении веера развития зависимости. Развитие традиционных форм зависимого поведения занимает несколько лет, а у $25 \%$ интернет-аддиктов формирование зависимости от интернета происходит через 6 месяцев после начала использования интернета, у 58\% - в течение следующих 6 месяцев, а у 17\% - через год. Исследователи указывают на то, что интернетзависимость стала мировым феноменом, и находится пока в умеренных границах, но уже сейчас наблюдаются страны, в которых «доля сильно и абсолютно зависимых пользователей становится статистически значимой». [8] Чтобы эта тенденция не приняла угрожающий характер, профилактика и борьба с интернет-зависимостью должна стать одним из приоритетных направлений государственной политики.

\section{Литература}

1. Белл, Д. Социальные рамки информационного общества // Новая технократическая волна на Западе / под ред. П. С. Гуревича. М., 1986. 451 с.

2. Носов Н.А. Виртуальная психология. М., 2000.

3. Клочко В.Е. Постнеклассическая наука и проблема объяснения в психологии. Методология и история психологии. 2008. Том 3. Выпуск 1. С.165

4. Меньшикова Г.Я., Зинченко Ю.П., Ковалев А.И., Шайгерова Л.А. Новые информационные технологии в социальных исследованиях: постнеклассическая парадигма. Национальный психологический журнал №3(19)/2015.С. 25-34

5. Селиванов В.В., Селиванова Л.Н. влияние средств виртуальной реальности на формирование личности. Непрерывное образование: ХХІ ВЕК. Выпуск 2 №14.2016. С.1-21

6. Коптева Н. В. Онтологическая уверенность при разной выраженности интернетзависимого поведения. Сибирский психологический журнал, №. 65, 2017, С. 6-21.

7. Кара Ж.Ю., Туз Р.О. Психологические аспекты интернет-аддикции. Южно-Российская межрегиональная научно-практическая конференция-выставка «Информационные технологии в образовании-2015» 11-12 ноября 2015

8. Варламова С., Гончарова Е., Соколова И. Интернет-зависимость молодежи мегаполисов: критерии и типология.

Князева Г.Н., Князева Е.В., Чепелева Л.М.

\section{СУБЪЕКТНЫЙ ПОДХОД К САМОДВИЖЕНИЮ СОВРЕМЕННОЙ ЛИЧНОСТИ КАК СУБЪЕКТА ОБРАЗОВАНИЯ}

Особым психическим механизмом, центрирующим, объединяющим все процессы самости личности, обозначенные первой частью слова «само», в том числе и «самообразование», является акмеологическое самодвижение. Изначально понимаем его как «само-систему» целостную и всеобъемлющую свойства субъекта непрерывного образования. Акмеологическое самодвижение выступает основополагающим мега-фактором вузовского и постдипломного образования и самообразования.

Один из основных законов непрерывного образования полагает акмеологическое самодвижение профессионала, будущего и состоявшегося, как профессионала-созидателя, творца, ваятеля. Именно это свойство обеспечивает постижение субъектом вершин профессионализма и продуктивности деятельности в процессе личностнопрофессионального самосовершенствования.

Философское понимание самодвижения как способа саморазвития предполагает обращение к вопросу развития психики. Так, А.В. Брушлинский отмечает, что в психологии сложились два подхода к развитию психики: культурно-исторический и знаково- 
центристский. Но в них существует несогласованность природного и социального, то есть культурного, по его мнению.

А.В.Брушлинский, подчеркивая единство природного и социального, утверждает подход субъектно-деятельностный. Для акмеологического самодвижения он имеет особое значение. А также посылка С.Л.Рубинштейна о том, что существует не только «зависимость сознания от бытия, от жизни...», но и «обратная зависимость бытия, жизни людей от сознания».

Ученые отмечают, что в триаде «активность - движение - развитие» осуществляется самоизменение в силу собственного действия субъекта и личность как система является социально обусловленной.

Субъектный подход к самодвижению человека как субъекта образования и самообразования рассматривает его с позиций Я-концепции человека в единстве четырех ипостасей: как индивида (продукт онтогенеза), личности (совокупность социально-значимых качеств), индивидуальности (уникальность и неповторимость свойств), субъекта деятельности (по Б.Г. Ананьеву). Человек трансформируется в социальной действительности, во взаимоотношениях изменяются его взгляды на социальную реальность и содержание собственного «Я», совершенствуется способность к систематическому самообразованию.

Подчеркнем, что главная, активная форма отношений личности как субъекта деятельности с миром в контексте акмеологического самодвижения - преодоление внутренних и внешних барьеров. Это ведущий механизм акмеологического становления.

Самостоятельность мышления и поведения «преодолевающего» человека в социуме обусловлены направленностью поведения к цели, стремлением превзойти среду и овладеть ею, реализуя социальный интерес (А. Адлер).

Психологическое понимание субъектного подхода к акмеологическому самодвижению субъекта образования на современном этапе обусловлено важнейшими методологическими положениями. Прежде всего, это: «Незнание движения необходимо влечет за собой незнание природы» (Аристотель). А также: «Самодвижение - собственное, внутренне необходимое изменение системы, порожденное противоречиями системы, опосредующей внешние факторы» (Ф.Ф. Вяккерев).

Современное цифровое образование с его цифровыми ресурсами сегодня органично дополняет внеурочную проектную учебную деятельность обучающихся, помогает развивать их познавательный и профильный интерес, поддерживая и организуя их самость.

Большую роль в образовательном процессе играет быстрый и простой доступ к сайтам музеев, сайтам ведущих библиотек, ссылки на электронные библиотеки.

Интерес к самосовершенствованию подкрепляют конкурсы и олимпиады, конференции и симпозиумы, организованные в сети Интернет.

Сегодня трудно не согласиться с тем, что намного легче учиться с помощью компьютера, так как это освоенная и удобная среда для современной молодежи. Компьютер - это не только инструмент для самообучения, быстрый способ получения нужной информации, это еще и продвижение от догматики до высокого уровня критического мышления. Процесс цифрового обучения отходит от общепринятых стандартов академического материала и повышает у обучающихся уровень критического типа мышления. Данное мышление необходимо для того, чтобы усвоить большое количество получаемой информации, отобрать в массе больших массивов данных ценную информацию.

Знание же компьютерных технологий повышает скорость самообучения, так как позволяет грамотно составлять запросы для наиболее релевантного отбора системами поиска нужной и полезной информации. Продуктивные результаты поиска, в свою очередь, делают самообразование более эффективным, а обучающихся более самостоятельными в получении верных выводов на основе анализа самостоятельно полученной информации.

Чтобы цифровое образование позитивно дополняло традиционное, необходимо и при создании электронных образовательных ресурсов обращать внимание на индивидуальные 
особенности каждого субъекта образовательного процесса, включая игровые моменты, моделирование ситуаций, ориентированность на возраст и т.д.

Цифровую грамотность подрастающего поколения следует использовать и развивать в целях быстрого усвоения ими получаемого материала. Цифровая среда богата различными новыми методами самообразования, в том числе коллективного. С помощью подключения к процессу обучения различных социальных сетей и видов онлайн-обучения, а также связанных с этим инструментов преподаватели могут раскрыть коллективный потенциал всех учеников и студентов. В этом случае будет использоваться самоорганизующийся обмен информацией между субъектами всего образовательного пространства.

К рассмотренной нами ранее способности преподавателя к реализации на высшем, акмеологическом, уровне следующих функций: а) «педагогического аристократизма» непременно добиться выполнения студентом «всего положенного» при соблюдении максимально уважительного отношения к нему (по принципу А.С. Макаренко: «Как можно больше требовательности к ученику и, вместе с тем, как можно больше уважения к нему»; б) «педагогического педантизма» - неукоснительного соблюдения точности 2 начала и завершения каждого учебного занятия (по принципу: «пунктуальность - порождение ответственности», «точность - вежливость королей»); в) реализации акмеологического подхода к обучению - ориентация на высший уровень самоорганизации деятельности студента под управлением преподавателя-предметника (оказание помощи каждому студенту в конструировании АСД (Авторской Системы Деятельности)) [1; с. 59] в современной образовательной системе добавляется еще одна важная функция - умение моделировать цифровое образовательное пространство, которое поможет осуществлять связь между приложениями, позволит импортировать данные для последующей обработки, и применять различные виды анализа, что, в свою очередь, приведет к максимальной автоматизации исследовательской деятельности [2; с. 38] всех субъектов образовательной системы. Значимость этой функции как основы личностно-профессионального самодвижения особенно проявляется в образовательном процессе магистратуры [3; с. 46]. Как сам процесс обучения по программе магистратуры, так и написание магистерской диссертации ориентированы на большую часть самостоятельной работы, на извлечение всех внутренних ресурсов обучающихся, их самоорганизации и ориентированности на результат.

Акмеологичность как проблема образования и его постоянной модернизации осуществляется с позиций акмеологического подхода, включающего системный, личностноориентированный, субъектно-деятельностный [4; с. 127].

Согласно положению 3.И. Рябикиной о том, что «в контексте бытийного подхода рассмотрение структуры личности предполагает, что бытие не только выступает внешней причиной, обусловливающей становление личности и её функционирование, но пространства бытия личности непосредственно включаются в её организацию» [5; с. 6], сегодня невозможно игнорировать цифровое пространство бытия личности. Следует только совершенствовать и использовать возможности цифрового образования для достижения акме в становлении личности.

\section{Литература}

1. Князева Г.Н., Князева Е.В., Чепелева Л.М., Блинова Т.В. Акмеолого-педагогическое сопровождение преподавания учебных дисциплин в вузе: воспитательный аспект. Научные труды Кубанского государственного технологического университета. 2014. № S4. C. 59-61.

2. Грушевский С.П., Князева Е.В. Развитие навыков информационного моделирования как активный метод профессионального обучения студентов гуманитарных специальностей. Экономические и гуманитарные исследования регионов. 2014. № 1. С. 108.

3. Князева Г.Н., Князева Е.В., Чепелева Л.М. Акмеологическая теория в профессиональной подготовке магистрантов средствами интерактивных методов обучения. Совет ректоров. 2013. № 2. С. 45-50. 
4. Князева Г.Н., Князева Е.В., Чепелева Л.М. Акмеологичность как условие модернизации образовательного процесса в вузе. Международный журнал экспериментального образования. 2013. № 4-1. С. 125-127.

5. Рябикина 3.И. Личность как субъект бытия и со-бытия: психологический аспект анализа // Личность и бытие: субъектный подход. Личность как субъект бытия: теоретикометодологические основания анализа: материалы III Всерос. науч.-практ. конф. Краснодар: Кубанский гос. ун-т, 2005.

Кругликова А.Ю.

\section{СОБЫТИЙНЫЙ ПОДХОД В ГРУППАХ СЕМЕЙНОЙ ЛОГОПСИХОТЕРАПИИ ДЛЯ ДОШКОЛЬНИКОВ}

На сегодняшний день актуальность проблемы своевременной логопсихокоррекции заикания у дошкольников обусловлена тем, что заиканием страдает примерно 1,5-2,5\% от всей детской популяции, включая подростков. Увеличение стажа заикания приводит к усугублению у детей отрицательных психических состояний, связанных с неудачным опытом общения, что провоцирует закрепление негативных черт характера (тревожность, страх речи, неуверенность в себе, необщительность) и нарастание трудностей адаптации и полноценной самореализации. У родителей заикающихся детей обычно отсутствует единое понимание проблемы заикания, что влечет разобщенность в их подходе к ребенку и к выбору методов и средств лечения. Это еще больше невротизирует семейную атмосферу, утяжеляя степень выраженности психологической надстройки заикания у детей. Отказ от раннего вмешательства хронифицирует речевой дефект и создает предрасположенность к возможным рецидивам в связи с последующим школьным обучением. Всё вышесказанное убеждает: преодоление заикания необходимо начинать уже в дошкольном возрасте, когда психика податлива, стаж заикания небольшой, а сопутствующие ему негативные черты пока еще не приобрели устойчивую форму.

Заикание (логоневроз) является вариантом нарушения темпоритма речи с выраженной психологической компонентой, вследствие чего на фоне повышенной тревожности возникают трудности в формировании всех сторон общения: коммуникативной, интерактивной и перцептивной. В связи с этим возрастает значимость разработки комплексных программ, построенных на интеграции и взаимопроникновении психологических, педагогических и психотерапевтических методов воздействия. Примером особого комплексного подхода в преодолении заикания у детей, подростков и взрослых является система семейной групповой логопсихотерапии Н.Л. Карповой - модификация методики групповой логопсихотерапии Ю.Б. Некрасовой, опирающейся на метод эмочионально-стрессовой психотерапии К.М. Дубровского, в которой заикание рассматривается как нарушение речевого общения [2]. Специфика указанной системы состоит в непосредственном и активном участии родителей и родственников заикающихся в работе социореабилитационной группы.

Семейные, в том числе детско-родительские отношения, особенно в дошкольном возрасте, выступают в роли наиболее значимых, их исследованию посвящены труды А.Я. Варга, А.И. Захарова, Н.Л. Карповой, А.И. Спиваковской, Д.Б. Эльконина, Э.Г. Эйдемиллера и В.В. Юстицкиса и др. [5]. Авторы рассматривают различные сферы детско-родительских отношений, их влияние на формирование личности ребенка, на выбор определенных моделей поведения и речевых стратегий при нормативном и нарушенном развитии, в том числе речевом. Необходимость включения семьи в реабилитационный процесс во многом определяется и тем фактом, что с середины прошлого столетия представление о неврозе как о болезни личности дополняется представлением о неврозе как о болезни семьи. В этом случае детско-родительские отношения становятся дисфункциональными и оказывают 
влияние на формирование в семье патогенных ситуаций, создавая опасность невротического развития личности, как это часто и бывает при заикании. По мнению Г.К. Ушакова, решающее влияние семьи определяется тем, что: 1) семья на ранних этапах развития человека является единственной, а позже одной из наиболее важных социальных групп, в которые он включен; 2) семейные отношения многосторонни и зависимы друг от друга: изменения одних вызывают «цепную реакцию» изменений во всех других; 3) члены семьи по отношению к различным внутрисемейным влияниям отличаются особой открытостью и, следовательно, уязвимостью [5; с. 35].

Адаптированный вариант семейной групповой логопсихотерапии для детей дошкольного возраста Н.В. Глуховой более 15 лет реализуется в муниципальном бюджетном дошкольном образовательном учреждении «Детский сад «Здоровый ребенок» г. Таганрога в группе компенсирующей направленности для детей, страдающих заиканием [1]. В семейной групповой логопсихотерапии для дошкольников детско-родительские отношения являются важным объектом воздействия, в связи с чем коррекционно-образовательный процесс в группе осуществляется по 4-м блокам: «Работа с детьми», «Работа с родителями», «Совместная работа с детьми и родителями», «Взаимодействие сотрудников».

Преодоление заикания у детей дошкольного возраста осуществляется поэтапно [1].

I этап - пропедевтический (сентябрь - октябрь, длительность 4-6 недель). Данный этап строится на динамической логопсихотерапевтической диагностике личностных и коммуникативно-речевых характеристик заикающегося ребенка, изучении его семьи.

II этап - мотивационно-установочный - игровой вариант сеанса эмоционально-стрессовой психотерапии (в конце октября), на котором присутствуют и родители.

III этап - активная семейная групповая логопсихотерапия (конец октября - апрель, длительность 6,5-7 месяцев); работа направлена на формирование и закрепление навыков речевого общения на фоне саногенных (оздоравливающих) психических состояний. Включает 2 периода: 1) «погружение» в систему логопсихотерапии - курс интенсивных ежедневных занятий в течение 7-10 дней с детьми и родителями; 2) период основного цикла коррекционных занятий с детьми и систематических занятий психолога с родителями.

IV этап - контрольно-поддерживающий (май, в течение 1 месяца); направлен на закрепление приобретенных навыков общения. Проверяется их устойчивость, гибкость, способность к психоречевой саморегуляции в бытовых и коммуникативных ситуациях.

Ключевым в реализации системы семейной групповой логопсихотерапии выступает логопсихотерапевтический подход, который интегрирует и другие подходы: семейно- $u$ личностно-ориентированный, личностно-деятельностный, возрастной и др. Научнопрактический анализ работы в дошкольных группах семейной логопсихотерапии, осуществляемой в режиме психолого-педагогического эксперимента, позволяет расширить представления об использовании и других инновационных подходов в коррекционнообразовательной практике. К ним относится и событийный подход.

О значимости событий в жизни человека неоднократно писал А.С. Макаренко: яркие и волнующие, они вызывают у детей позитивный эмоциональный отклик, создают ноту оптимизма и побуждают становиться лучше. Подобное отношение к событиям школьной жизни разделял и В.А. Сухомлинский, отмечая, что их многообразие, богатство и логика взаимоотношений призваны создавать особую воспитательную атмосферу школы - «живое общение», «живые дорожки от сердца к сердцу». Для обозначения такой среды педагог ввел понятие уклада, который, в отличие от целенаправленных, отрепетированных и потому формальных мероприятий, всегда - живая событийность, пересечение неформальных пространств «живого» общения с детьми, отвечающих потребностям каждого ребенка.

Отметим, что в полной мере идеи событийного подхода впервые стали «оживать» в пространстве российского (советского) образования в конце 80-90-х гг. прошлого столетия. Его теоретическое обоснование содержится в теории общего психического развития В.И. Слободчикова и соответствующей ей возрастной периодизации [4; с. 40]. Согласно автору, общий ход психического развития человека совершается как прохождение им 
последовательных ступеней развития субъектности в со-бытийной общности, «внутри которой и образуются собственно человеческие способности, позволяющие индивиду, вопервых, входить в различные общности и приобщаться к определенным формам культуры, а во-вторых, выходить из общности, индивидуализироваться и самому творить новые формы, т.е. быть само-бытным» [4; с. 40]. Исходя из этого, главным вектором развития человека выступает становление его субъектом собственного развития, а пространством - событийная общность - подлинный субъект развития и саморазвития в период становления личности ребенка.

Со-бытийность (бытие с другими) является основой формирования собственного культурного опыта ребенка, посредством различных событий ребенок приобщается к социокультурным процессам. Событие создает подлинную ситуацию развития, что позволяет ребенку действительно «встать в отношение» к окружающей среде, к собственной жизнедеятельности. В современной образовательной практике событийный подход рассматривается как продуктивная технология организации и осуществления значимых событий в жизни детского коллектива и отдельной личности.

Рассмотрим использование событийного подхода в практике семейной групповой логопсихотерапии для дошкольников, где одним из объектов коррекционнопсихологического воздействия со стороны специалистов выступает со-бытийная общность «дети - родители - педагоги». В качестве примера проанализируем организацию недели «погружения в семейную логопсихотерапию», которая предстает как цикл ежедневных интегрированных занятий (событий) на III этапе логопсихокоррекции [3]. Цель данного периода - создание у всех участников группы мотивационной включенности в предстоящий активный логопсихотерапевтический процесс, вызывание устойчивых позитивных психических состояний и формирование на базе общегрупповой деятельности единого детско-взрослого коллектива. Неделя «погружения» позволяет: детям - войти в игровую ситуацию преодоления речевых и психологических трудностей; родителям - глубже понимать своего ребенка, его проблемы, ресурсы свои и семьи в целом для активной помощи; педагогам - изучить «психологический портрет» ребенка, семьи, каждого родителя и определить наиболее эффективные стратегии и методы воздействия в соответствии с потребностями и возможностями участников процесса. В процессе работы объектом пристального внимания и субъектом реализации всех задач является формирующаяся разновозрастная детско-родительская группа.

«Погружение» всех членов семьи одновременно в единый логопсихотерапевтический процесс позволяет ввести всю семью в единый речевой режим, единое «смысловое поле» и единую (близкую) динамику состояний. На совместных детско-родительских встречах у родителей дошкольников появляется возможность «прожить» совместно со своим ребенком значимые события (вхождение в новый коллектив, первые контакты, освоение правил речевого общения, встреча с различными образовательными областями, первый опыт речи на публике и пр.). Это позволяет им «прочувствовать» речевые трудности своего ребенка в разных ситуациях общения, понаблюдать детей, преодолевших заикание, и увидеть возможные перспективы для своего ребёнка.

В свою очередь, заикающиеся дошкольники от 3-х до 7-ми лет, находясь в разновозрастном взросло-детском коллективе, вступают в многообразное и разноуровневое общение как со сверстниками, так и с детьми старше или младше (братья и сестры заикающихся), также и с взрослыми участниками, включая чужих родителей, дедушек и бабушек и других родственников. Возрастной градиент группы обычно находится в пределах от 1 года до 65-70 лет. В подобных условиях своеобразного коммуникативно-речевого тренинга дошкольники имеют возможность овладевать речевыми умениями и эффективными коммуникативными стратегиями. Это способствует повышению их уверенности в себе и расширяет субъектные возможности: самостоятельность, активность, инициативность, готовность к выбору, способность сотрудничать и взаимодействовать с людьми разного возраста, уровня образования, социального положения и жизненного опыта. 
Введение речевого режима - полного стиля произношения - предполагает соблюдение особых правил речи, минимизирующих/устраняющих число запинок и судорог. Учитывая конкретность мышления и образность восприятия дошкольников, знакомство с «необычным языком» происходит спонтанно, с помощью игровых приемов и посредством подражания. При этом правильная организация речевой среды в детском саду должна поддерживаться такой же речевой средой в семье. В данный период с детьми и родителями на общих и раздельных занятиях организуется работа по постановке диафрагмального дыхания, голоса, отработке навыков замедленной плавной речи, интонации, навыков саморегуляции с использованием логопсихотерапевтических технологий.

Предлагая различные формы работы в качестве значимых событий, педагоги и специалисты планируют совместные детско-родительские занятия, например, «Семейные планеты», «Правила речи», «Моя семья», «Наша группа». На тематических занятиях с психологом («Дракон заикания», «Семейное воспитание», «Детские страхи»), в процессе проективного рисования («Мой ребенок в образе растения (животного)», «Кувшин состояний», «Герб семьи») родители обсуждают особенности и потребности своего ребенка, проблемы детско-родительских отношений в семье, участвуют в анкетировании и тестировании. Опираясь на полученные данные, педагоги уточняют наиболее оптимальный путь социореабилитации заикающегося ребенка и членов его семьи, разработают для воспитанников индивидуальные программы развития, включающие коррекционную, развивающую, воспитательную и общеобразовательную работу в детском саду.

В конце недели «погружения» подготавливается яркое событие, позволяющее интегрировать все достижения детей и взрослых, полученные в ходе работы. Обычно это праздничное действо, где каждой семье предоставляется возможность публично представить всех ее членов в любой форме: драматизация сказки, разыгрывание стихотворения, творческое выступление с включением музыки, вокала, игры на музыкальных инструментах. Организация итогового события реализуется как совместный тематический проект, например, «Мир увлечений», «Путешествие в Страну Красивой Речи», «В мире сказок», «Огни цирка» и т.п. Единственное требование - показать освоенность полного стиля произношения, навыка публичного выступления и творческий подход, приветствуется самостоятельность и творческая активность семьи. Цикл занятий - событий, соответствующих неделе «погружения», подробно описан в коллективном сборнике «Семейная групповая логопсихотерапия для дошкольников: 15 лет спустя» [3; с. 149-174].

Реализуя событийный подход в дошкольных группах семейной логопсихотерапии, его организаторы учитывают принципиальные положения о роли со-бытийной общности и значимых событий в развитии личности (по В.И. Слободчикову):

1) со-бытийная общность - это система отношений, где, независимо от возраста, возникают и развиваются субъектные качества человека, позволяющие ему приобщаться к культуре, индивидуализироваться и творчески проявлять свою субъектность;

2) члены со-бытийной общности (дети и родители) в пространстве значимого события испытывают высокое эмоционально-интеллектуальное напряжение, ощущают единство и сопричастность, общность психических состояний, переживаний и смыслов, вследствие чего формируется чувство «Мы», «Мы - группа», «Мы как одна семья»;

3) каждое организуемое событие имеет «деятельностный фундамент», представляя завершенное действие от мотива до результата с последующей рефлексией и выходом на другие события, созданием «продукта совместной деятельности», что требует активного сотрудничества и со-творчества всех участников со-бытийной общности;

4) событие предполагает определенную внутреннюю (эмоциональную и нравственную) работу детей и родителей - переживание и со-переживание, творческое проживание событие - при этом получают новый опыт, знания, познавая свои возможности и способности; для этого события организуются так, чтобы все участники являлись не столько зрителями, сколько его реальными участниками. 
Организация недели «погружения» как череды эмоционально значимых, несущих коррекционно-развивающий потенциал событий в пространстве со-бытийной общности детей и взрослых, позволяет достичь важных результатов в самом начале активной работы по преодолению заикания. У детей: а) уменьшается число запинок, снимается излишняя мышечная напряженность; б) формируется легкость и свобода в общении, самостоятельность и инициативность; в) развивается умение использовать разнообразные речевые и психологические средства для поддержания общения; г) реализуется возможность выражать в речи свое эмоциональное состояние.

Родители детей также проходят свой путь личностного роста: а) осознают причины, вызывающие заикание, и те характеристики детско-родительских отношений, которые его усугубляют; б) лучше понимают и принимают своего ребенка и свою роль в преодолении речевого нарушения, получая навыки, как помогать и поддерживать сына или дочь в ситуациях затруднений; в) обретают веру в способности и возможности своего ребёнка; г) овладевают навыками полноценного диалогического общения в семье, д) начинают ценить себя, уважать свои личностные и творческие потребности. Все это улучшает детскородительские отношения.

Анализ работы по системе семейной групповой логопсихотерапии с заикающимися дошкольниками на примере недели «погружения» в рамках событийного подхода позволяет сделать выводы:

1. Событийный подход способствует развитию субъектности как взрослых, так и детей дошкольного возраста: активизирует стремление к самостоятельности, развивает творческое отношение к собственной деятельности, открывает возможности для осуществления выбора в пределах возрастных возможностей, формирует позитивные психические состояния как основу для преодоления речевых и психологических проблем.

2. Каждое событие актуализирует мотивацию и готовность к целенаправленной, эмоционально окрашенной деятельности: потребность в достижении нового опыта, постановка цели, выбор средств, концентрация внимания на последовательном выполнении действий, проверка правильности решения, оценка результата.

3. Со-бытийность, представленная как взаимоотношения и взаимодействие детей и взрослых, способствует повышению мотивации к саморазвитию и самообразованию. В событийной детско-взрослой общности возникает пространство взаимообогащения и взаимоподдержки, столь необходимой для преодоления заикания у дошкольников.

4. Участники логопсихотерапевтического процесса, независимо от возраста, являются равноправными участниками, каждый из которых вносит свой вклад (деятельностный, эмоциональный, познавательный) в формирование и развитие со-бытийной общности, которая сама становится пространством, обладающим развивающим потенциалом.

5. Каждое реализованное событие является результатом сотрудничества и сотворчества детей и взрослых (педагогов и родителей). Эмоционально значимое событие предстает как со-бытие (бытие с другими) взрослых и детей, в пространстве которого посредством диалога происходит взаимопересечение детской и взрослой культур, обогащение нормами, ценностями, смыслами (общие, индивидуально-личностные).

6. Неделя «погружения в семейную групповую логопсихотерапию», организованная как цикл эмоционально-насыщенных событий, запускает процесс преодоления заикания у детей, a также коррекции детско-родительских отношений, в результате чего оказывается позитивное воздействие как на устранение симптома, так и на гармонизацию эмоциональноличностного развития дошкольника.

\section{Литература}

1. Глухова Н.В. Семейная групповая логопсихотерапия для заикающихся дошкольников в условиях детского сада. Программа / Под ред. Н.Л. Карповой. - Таганрог, 2005. - 142 с.

2. Семейная групповая логопсихотерапия: исследование заикания / Под ред. Н.Л. Карповой. - СПб.: Нестор-История , 2011. - 328 с. 
3. Семейная групповая логопсихотерапия для дошкольников: 15 лет спустя / ред.-сост. А.Ю. Кругликова. - Таганрог: изд-во «Нюанс», 2017. - 242 с.

4. Слободчиков В.И., Цукерман Г.А. Интегральная периодизация общего психического развития // Вопр. психол. 1996. № 5. С. 38-50.

5. Эйдемиллер Э.Г., Добряков И.В., Никольская И.М. Семейный диагноз и семейная психотерапия. Учеб. пособие для врачей и психологов. СПб.: Речь, 2003. - 336 с.

Крутелева Л.Ю.

\section{ВЗАИМОСВЯЗЬ ДЕТСКО-РОДИТЕЛЬСКИХ ОТНОШЕНИЙ И СЕМЕЙНЫХ СЦЕНАРИЕВ У ЖЕНЩИН СРЕДНЕГО ВОЗРАСТА}

В современной науке уже давно доказано, что формирование ценностно-смысловой сферы, а на ее основе и личности, и характера человека происходит в раннем детстве. Семья, как первый и главный транслятор духовных ценностей и моделей поведения, несет в себе основной массив смыслов и традиций, которые передаются из поколения в поколение.

Довольно часто в бытовом контексте можно услышать такие фразы, как: «все мы родом из детства» или «раненный в детстве», что указывает не только на ведущую роль семьи в воспитании ребенка, но и на некоторый неуспех родителей в данном процессе. Микрокультура взаимоотношений в семье (между супругами, между родителями и детьми) определяет те модели и взгляды на семью, на роли супругов, на воспитание детей и т.п., которые в дальнейшем дети будут использовать при построении своей собственной семьи.

В психологии достаточно много работ как российских, так и зарубежных ученых посвящено вопросам воспитания детей и детско-родительских отношений (А. Адлер, Дж. Боулби, А.Я. Варга, Л.С. Выготский, Ю.Б. Гиппенрейтер, Р. Дрейкус, В.И. Дружинин, Т.В. Корнеева, Я. Корчак, А.С. Макаренко, Л.Ф. Обухова, Л.В. Петрановская, К. Роджерс, А. Фрейд, Д.Б. Эльконин, Э. Эриксон и многие другие). Тем не менее, такие аспекты, как влияние взаимоотношений отца и матери и их отношения к дочери на формирование личностных характеристик у дочери и ее будущих семейных сценариев остаются не достаточно изученными и представлены в научной литературе только частично (Ж.Н. Дюльдина, К.В. Морозова; О.Г. Исупова; О.А. Карабанова, О.В. Трофимова; С.В. Мерзлякова; Т.В. Пфау, Т.В. Садолина; С.А. Сероветникова, Н.А. Рачковская; М.Р. Хабибулина; К. Бартоломеус, Д.У. Риггз и другие) [1-11].

В связи с этим, совместно со А.А. Спивак, нами было проведено исследование, в котором приняли участие женщины двух возрастных групп (20-35 лет и 36-50 лет), условно обозначенные как группа «девушки» (28 человек) и группа «женщины» (25 человек).

В качестве методического инструментария нами были использованы такие методики, как «Тест смысложизненных ориентаций» («PIL» Д. Крамбо и Л. Махолик [модификация Д.А. Леонтьева]), опросник «Ролевые ожидания и притязания в браке» (А.Н. Волкова), тест на межличностную зависимость: любовную, от партнера, в детско-родительских отношениях (методика Р. Гиршфильда, адаптация О.П. Макушиной), авторская анкета (Л.Ю. Крутелёва, А.А. Спивак) для изучения взаимоотношений отца и матери между собой и их отношения к дочери в родительской семье, а также выявления семейных сценариев в собственной семье дочери.

В результате проведенного исследования мы можем сделать следующие выводы.

При подробном качественном и статистическом анализе данных мы обнаружили, что ценностно-смысловые установки, направленные на брак и семью, и отношения со значимыми другими у женщин изменяются в зависимости от их возраста: становясь старше, женщина чувствует большую уверенность в себе, уровень осмысленности ее жизни становится возрастает. Так исследование показало, что для женщины среднего возраста общность интересов с супругом выходит на первый план. При этом ожидания и притязания 
по вопросу внешней привлекательности становятся менее актуальными по сравнению более молодыми участницами исследования. Также можно отметить, что у группы девушек более высокие требования к себе в области социальной активности, а группа женщин больше склонна к решению хозяйственно-бытовых вопросов.

Исследование взаимоотношений женщин с отцом и матерью в детстве показало, что при достаточном контейнировании эмоций в детстве во взрослом возрасте респонденты способны успокоить самих себя и оказать помощь окружающим. Для тех женщин, которые в детстве не получили достаточной эмоциональной поддержки от родителей, во взрослом возрасте примерно до 35 лет проблема управления собственными эмоциями является актуальной и острой. Однако после 35 лет женщина или учится контейнировать свои эмоции самостоятельно или настолько отказывается от них, что перестает искать эмоциональную поддержку от других.

Изучение влияния поддержки родителей на самооценку и уверенность в себе женщин подтвердило тот факт, что девочки, которых родители (вне зависимости оба, отец или мать в отдельности) в детстве поддерживали, хвалили, помогали пережить неудачи, вырастают достаточно уверенными в себе личностями с более стабильной самооценкой. Девочки, которых в детстве часто критиковали или в жизни которых родители просто не принимали эмоционального участия, имеют проблемы с самооценкой. Важно также отметить, что наличие собственного развода или развода родителей значимо влияет на самооценку женщины во взрослом возрасте, снижая ее, т.е. даже при достаточной поддержке от обоих родителей, женщины, пережившие развод или выросшие в семье, которая прошла через развод, все равно испытывают проблемы с самооценкой и склоны к неуверенности в себе.

Анализ отношений со значимыми другими (отцом, матерью) и их влияния на формирование ценностно-смысловых установок, направленных на брак и семью, у женщин среднего возраста позволил выделить два основных компонента, которые определяют сценарии поведения в собственных семьях взрослых женщин:

- эмоциональная составляющая семьи (стремление к роли эмоционального лидера, способность регулировать эмоциональный климат в семье),

- а также хозяйственно-бытовые отношения (стремление иметь решающий голос в решении семейных вопросов, готовность отдать лидерство своему избраннику).

Полученные данные свидетельствуют о том, что женщины, воспитанные в семьях, где отец брал ответственность на себя, решая ежедневные проблемы, склонны выбирать роль второго плана в своей собственной семье. Однако с возрастом женщина имеет тенденцию разделять ответственность и участвовать в семенных вопросах «на равных».

Исследование эмоционального климата, который рассматривался, как взаимоотношения родителей друг с другом, а также отношения отца, матери и дочери в целом, показали, что если девочка воспитывалась в семье, в которой родители в силу различных причин уже не имели тесного эмоционального контакта между собой, но разделяли все чувства и эмоции ребенка, поддерживая ее, то она с готовностью берет на себя роль эмоционального лидера в своей собственной семье; если же подобной поддержки в детстве не было, то женщина склонна искать мужчину, способного регулировать психоэмоциональный климат внутри семьи. Кроме того, прослеживается определенная тенденция переноса распределения ролей в своей собственной семье в соответствие с тем, какие позиции занимали отец и мать в родительской семье: женщины, воспитанные в традиционных патриархальных семьях, стремятся найти мужчину с такими же характеристикам, как их отец; женщины же, выросшие в неполной семье или в семье с матриархальным укладом, готовы сами брать на себя ответственность, решать различного рода проблемы, сохраняя автономию даже после вступления в брак.

Статистический анализ данных с применением расчета коэффициентов ранговой корреляции Спирмена показал, что степень зависимости женщин от других людей прямо пропорциональна степени неуверенности в себе и уровню потребности в эмоциональной опоре на других. Кроме того, эмоционально-психотерапевтические ролевые притязания в 
собственном браке у женщин также прямо пропорционально зависят от степени выраженности эмоционального контакта с родителями в детстве, а также от общего психоэмоционального климата в родительской семье и контейнирования негативных эмоций.

Таким образом, говоря о закономерности со-бытийности и, в частности, о проявлении детско-родительских отношений в семейных сценариев у женщин среднего возраста, на основе проведенного исследования можно еще раз подтвердить, что психоэмоциональный климат в родительской семье и непосредственное общение родителей с детьми оказывает критическое влияние на особенности ценностно-смысловой сферы детей и их дальнейшие сценарии поведения во взрослой жизни.

Перспективой данного направления исследования является изучение различий ценностносмысловых установок, направленных на брак и семью, у женщин, воспитанных в полных и неполных семьях, а также исследование влияния развода (собственного и/или родителей) на формирование личности женщины и ее будущих семейных сценариев.

\section{Литература}

1. Дюльдина Ж.Н., Морозова К.В. Психолого-педагогические аспекты роли отца в воспитании ребенка в семье. // Поволжский педагогический поиск. 2013. № 3 (5), С. 73-76.

2. Исупова О.Г. Материнская карьера: дети и трудовые стратегии. // Социологические исследования. 2015, № 11, С. 100-120.

3. Карабанова О.А., Трофимова О.В. Роль родительской семьи в формировании образа будущей семьи. // Современная российская семья: психологические проблемы и пути их решения: моногр. - Астрахань: Астраханский университет, 2013. - С. 14-21.

4. Мерзлякова С.В. Родительская семья как ориентирующий образ семейного самоопределения молодежи. // Теория и практика общественного развития. 2014, № 2, С. 114-119.

5. Пфау Т.В., Литвякова Н.Н. Родительское отношение отца и отчима к дочери старшего дошкольного возраста. // Вестник по педагогике и психологии Южной Сибири. 2016, № 3, С. 187-195.

6. Садолина Т.В. Эмоциональная составляющая социально-психологического содержания отношений дочери с отцом и их влияние на выбор будущего супруга. // Молодой ученый. 2012, № 9, С. 253-255.

7. Сероветникова С.А., Рачковская Н.А. Внутренние и внешние факторы воспитания ценностных ориентаций старшего подростка в учебной деятельности. // Фундаментальные и прикладные исследования: проблемы и результаты: труды Международной научнопрактической конференции, 2016. / Под. ред. Л.И. Рогачевой; Филиал РГСУ в г. Дедовске МО. - М.: ИИУ МГОУ, 2016. - С. 5-10.

8. Хабибулина М.Р. Роль отца и девиантное поведение дочери в подростковом возрасте. // Молодой ученый. 2013, № 3, C. 448-450.

9. Bartholomaeus C., Riggs D.W. Daughters and their mothers: The reproduction of pronatalist discourses across generations. // Women's Studies International Forum, Volume 62, May-June 2017, Pages 1-7.

10. Teen Daughters and Their Mothers in Conversation: Identifying Opportunities for Enhancing Awareness of Risky Tanning Behaviors. // Journal of Adolescent Health, Volume 58, Issue 5, May 2016, Pages 579-581.

11. Transmission of risk preferences from mothers to daughters. // Journal of Economic Behavior \& Organization, Volume 134, February 2017, Pages 60-77. 


\section{ПРАВОСЛАВНАЯ ВЕРА КАК ОСНОВА ЖИЗНЕННОГО МИРА ЧЕЛОВЕКА}

Стремительное и масштабное изменение онтологии человеческого существования отмечается почти всеми исследователями. Это проявляется в том, что время как одна из характеристик жизненного мира приобретает все больше качество текучести, неуловимости. В свое время Э. Тоффлер предсказал появление «шока будущего», связанного с темпами изменений, когда скорость изменения социальной жизни превращает ее в «постоянно исчезающую ситуацию» [9]. Как пишет Гришина Н.В., ощущение дефицита времени порождает ощущение утраты контроля над временем, ситуацией, своей жизнью. Чувство контроля является важной опорой, источником уверенности в себе, помогает противостоять стрессу и преодолевать жизненные трудности Рваный фрагментарный ритм, утрата связности времени приводит к нарушению логики жизни. Человек теряет ощущение подлинности, реальности происходящего, не может в полной мере оценивать действительность с позиции морального выбора между добром и злом [2; с. 294]. Из-за ускорения темпов изменения реальности происходит «сжатие времени», укорочение жизненной перспективы. Кривошеев В.В. отмечает, что «укорачивание» пространственновременных аспектов индивидуальной и социальной жизни приводит к ощущению ее непрочности, ненадежности, необходимости непрерывного приспособления к этому неуловимо изменчивому миру [4]. В силу своей изменчивости внешний мир содержит все меньше ориентиров для принятия решений и выбора форм поведения, все большую роль начинают играть внутренние установки, все больше требуется от человека наличия авторской позиции в своей жизни. Один из основных вызовов, обращенный к индивидуальности человека, связан с необходимостью жизнетворчества, использования стратегий конструирования собственной жизни $[3,8]$. Большинство исследователей этой проблемы подчеркивает, что стратегии жизнетворчества всегда индивидуальны и уникальны.

Большой интерес в связи с описанными выше трансформациями жизненного мира современного человека представляет обращение к феномену религиозной веры как основе жизнетворчества. Актуальность рассмотрения этой проблемы обусловлена тем, что в последнее время во всех слоях нашего общества наблюдается повышенный интерес к православной вере и стремление вернуть в свой жизненный мир опыт общения с православной Церковью, который многие века определял особенности и психологический облик людей, живущих в России. При этом многих привлекает именно то, что система христианского мировоззрения целостна, универсальна и не зависит ни от времени, ни от других внешних обстоятельств. Это не только одно из лучших средств адаптации в изменяющемся мире, но и система координат, позволяющая формировать свой жизненный мир на твердых основаниях веры.

Апостол Павел пишет: «Вера же есть осуществление ожидаемого и уверенность в невидимом» [Евр.11:1]. В этом определении пространственно-временные характеристики мира вынесены за скобку. Вера не от мира сего. (Речь идет о еще несовершившемся во времени и невидимом в пространстве). Вера поднимает человека над проблемами ускорения темпа жизни, стрессами, дает ясные нравственные ориентиры. Сами сущностные характеристики веры формируют у человека субъектное отношение к своей жизни.

Проповедник 19 века протоиерей Василий Михайловский приводит следующий перечень обязательных характеристик истинной веры [7]:

1. Простосердечность, которая проявляется в смирении сердца перед тайной Бога, в сердечном доверии к Богу.

2. Истинная вера должна проявляться в делах. Это не только вероучительная система, но и образ жизни. Человек должен ощутить свой талант, данный ему Богом, и найти свое место в мире.

3. Постоянство веры. 
Этот перечень показывает, что в проявлениях веры с самого начала заложена активная субъектная позиция человека. Сама цель христианской жизни - это преображение человека, освобождение от греховного, падшего состояния и приближение его к общению с Богом. Преподобный Серафим Саровский говорил о том, что цель человеческой жизни - это стяжание Духа Святого, что невозможно без постоянной внутренней работы по очищению своей души от греховных страстей и ее просветлению. Вдохновляющая идея преображения, возможного для любого человека, является мощным мотивирующим фактором, придающим смысл жизни и побуждающим верующего человека строить свой индивидуальный жизненный мир, исходя из принципов христианского вероучения.

Принято считать, что современный человек полностью погружен в ситуацию неопределенности, в результате чего он вынужден вырабатывать те или иные приемы, способствующие повышению толерантности и позволяющие выживать в этой среде. Однако гораздо более продуктивное отношение к этой же ситуации считать ее неДОопределенной, что приводит к возможности конструктивного и креативного подхода. И тут очень важно, что именно лежит в той части субъектного отношения к ситуации, которая содержит в себе определенность. Это могут быть какие-либо предрассудки, паралогизмы, некритично принятые допущения; а могут быть выверенные, испытанные жизнью основания, на которых уже не раз принимались решения серьезных проблем. В первом случае дело может ограничиться выработкой более или менее эффективных, но временных эго-защитных механизмов, отгораживающих от неопределенностной бездны. В случае же опоры на основания (каковыми как раз и являются глубокие и крепкие верования) приобретается и накапливается жизненный опыт, равносильный мудрости. В православной аскетике одной из главных добродетелей считается рассудительность. Древний исследователь монашеского аскетического опыта преподобный Иоанн Кассиан Римлянин (IV в.) писал: "В рассудительности состоит премудрость, в ней разум и смысл, без которых нельзя ни созидать наш внутренний дом, ни собирать духовное богатство, как сказано: "Мудростью устрояется дом и разумом утверждается, и с уменьем внутренности его наполняются всяким драгоценным и прекрасным имуществом" (Притч.24:3)". Преподобный Иоанн Лествичник (VII в.) указывал этапы развития этой добродетели: "Рассуждение в новоначальных есть истинное познание своего душевного устроения... В средних оно есть чувство, которое непогрешимо различает истинно доброе от естественного и от того, что противно доброму... В совершенных рассуждение есть находящийся в них духовный разум, дарованный Божественным просвещением, который своим светильником может просвещать и то, что есть темного в душах других" [6] . Понятно, что все эти способности раскрываются на прочном основании веры. Вера стабилизирует жизненный мир субъекта как в отношении временной "текучести" реальности, так и в отношении дискретности, фрагментации, разорванности социального пространства, в котором вынужден пребывать современный человек. При этом вера освобождает его от закабаления жесткой социально-ролевой детерминацией, раскрывая для него иные внепространственные измерения. Апостол Павел утверждал: «...Я уверен, что ни смерть, ни жизнь, ни Ангелы, ни Начала, ни Силы, ни настоящее, ни будущее, ни высота, ни глубина, ни другая какая тварь не может отлучить нас от любви Божией во Христе Иисусе, Господе нашем» (Рим.8:38-39).

М.В.Ломоносов писал: «Создатель дал роду человеческому две Книги. В одной показал Свое Величие, в другой - Свою Волю. Первая - видимый сей мир, им созданный, чтобы человек, смотря на огромность, красоту и стройность его зданий, признал Божественное Всемогущество, по мере себе дарованного понятия. Вторая книга - Священное Писание. В ней показано Создателево благоволение к нашему спасению... Обе обще удостоверяют нас не только о бытии Божием, но и о несказанных Его к нам благодеяниях. Грех всевать между ними плевелы и раздоры!» [5]. В апологетической литературе часто приводится эта цитата для доказательства отсутствия противоречий между наукой и религией. В приведенном высказывании речь идет о том, что существующий материальный мир как творение Божие человек может познавать с помощью своего разума (по мере себе дарованного понятия), что 
находит выражение в научном познании действительности, но ему кроме этого дано и Священное Писание, в котором изложены основные принципы правильного устроения своего жизненного мира, следуя которым можно спасти душу.

Заметим, что даже в так называемых точных и фундаментальных науках трудами науковедов обнаруживаются вненаучные основания [10]. И уже вполне доказано (вопреки позитивистским и сциентистским установкам), что эти основания по своей сути глубоко религиозны (П. П. Гайденко, Л. М. Косарева, И. А. Непомнящих, В. С. Степин, В. Н. Катасонов, А. А. Игнатенко и др.). Это можно отнести и к психологии и особенно к психотерапии. К.Ясперс еще на начальных этапах развития психотерапии писал, что именно «религия (или ее отсутствие) определяет цели психотерапевтического воздействия» [11; с. 945]. Василюк Ф. Е. отмечал, что ключевой принцип нынешнего этапа развития мировой психотерапии заключается в сознательном философском самоопределении психотерапевтических школ по отношению к религии. [1; с. 182]. Следует признать, что такое самоопределение происходит и в отечественной психологии, что нашло выражение в выделении в последние годы особого направления христианской психологии и православной психотерапии, имеющих своей целью не только научное осмысление тех координат жизненного мира, которое задает православное вероучение, но и оказание реальной практической помощи в воплощении этого мира в бытии человека.

\section{Литература}

1. Василюк Ф. Е. Переживание и молитва (опыт общепсихологического исследования). М.: Смысл, 2005. - 191 с.

2. Гришина Н. В. Экзистенциальная психология: учебник. - СПб., 2018. - 494 с.

3. Знаков В.В. Экзистенциальный опыт субъекта как проблема психологии человеческого бытия // Субъектный подход в психологии / под ред. А. Л. Журавлева, В. В. Знакова, 3. И Рябикиной, Е. А. Сергиенко. - М., 2009. С. 211-225.

4. Кривошеев В. В. Короткие жизненные проекты: проявление аномии в современном обществе // Социологические исследования. 2009. № 3. С.57-67.

5. Ломоносов М. В. Явление Венеры на Солнце, наблюденное в Санктпетербургской императорской Академии Наук майя 26 дня 1761 года / Ломоносов М. В. Полное собрание сочинений / АН СССР. - М; Л., 1950 - 1983. Т.2: Труды по физике, астрономии и приборостроению, 1744 - 1765 гг. - М.; Л.: АН СССР, 1955. С. 375.

6. Преподобный Иоанн Лествичник. Лествица, возводящая на небо. - М.: Издательство Сретенского монастыря, 2002. - 368 с.

7. Протоиерей Василий Михайловский. Полная исповедь. - М.: Изд-во «Летопись», 2016. - $112 \mathrm{c}$.

8. Рябикина 3. И. Перспективы в рассмотрении личности как субъекта бытия // Личность и бытие: субъектный подход: материалы V Bсерос. науч.-практ. конф. / под ред. З.И.

Рябикиной, В.В. Знакова. - Краснодар: Кубанский гос. ун-т, 2010. С. 36-39.

9. Тоффлер, Э. Шок будущего. - М.: Издательство АСТ, 2008. - 560 с.

10. Франк Ф. Философия науки. Связь между наукой и философией: Пер. с англ. / Общ. ред. Г. А. Курсанова. Изд. 2-е. - М.: Издательство ЛКИ, 2007. - 512 с.

11. Ясперс К. Общая психопатология. - М.: Практика, 1997. - 1056 с.

Макаревская Ю.Э., Рябикина 3.И.

\section{ФАКТОРНЫЙ АНАЛИЗ ПРИЗНАКОВ ЛИЧНОСТНОЙ ИДЕНТИЧНОСТИ}

В современном мире вся совокупность идентификационных ориентиров и самих идентичностей личности, представленных в глобальном пространстве, пребывает в состоянии преобразований. 
Вся система позиционирования личности и группы теряет прежнюю определенность и становится объектом конструирования как со стороны самих себя, так и со стороны внешних для них субъектов трансформации идентичности. Примером данного явления может быть стремление к общеевропейской идентичности людей, проживающих в Европе.

Под идентичностью личности сегодня можно понимать

- узнавание и отождествление (в дословном переводе с лат.);

- тождество (рус., Ожегов С.И., 1974)

- целостность целей, установок, убеждений, определяющих социальное развитие личности, а также ее последовательное и непротиворечивое взаимодействие с обществом (например, Кимберг, 2005; Злоказов К.В., 2015 и др.)

При наличии разного вида социальных идентичностей, требующих соотнесения себя с другим, личностная идентичность, является

- одновременно идентификационным процессом, майнстрим (Г.Г. Танасов, 2011, 3.И. Рябикина, 2014);

- $\quad$ результатом (субъективное ощущение тождества, узнавание своей сущности по Э. Эриксону, 1996) персональных интегративных процессов, образованием достаточно автономным и устойчивым, чтобы позволить субъекту при наличии большинства сохранять мнение меньшинства (по 3. Фрейду).

Процессуальность идентичности предполагает возможность управления процессом. Управление применительно к идентичностям означает, что они могут более или менее осознанно, целенаправленно конструироваться, деконструироваться, форматироваться, переформатироваться, иначе говоря, меняться.

Результативность идентичности предполагает переживание своего совпадения с (эталоном, шаблоном, ожиданием, впечатлением). Э. Эриксон говорил о восторженном или болезненном чувстве идентичности при осознании мысли «вот это и есть настоящий Я».

Идентичность - это ядро, связующее воедино все психические процессы, сферы личности, дающее личности возможность организовывать субъектную активность, продлевать себя в социуме, в бытийных пространствах.

Это личностное образование дает персоне ощущение себя, самости даже в отсутствии других людей или при попадании в иную бытийную и со-бытийную среду.

Естественно, мы понимаем, что существует идентичность с самим собой и с таким же. В первом случае другой не нужен, во втором личности необходимо хотя бы редкое появление другой персоны для сравнения.

Исследования, проведенные нами с 2006г. и по настоящее время, направлены на прояснение того, что именно нужно сравнивать у себя для сохранения собственной (личностной) идентичности? То есть, исследовательский интерес был сосредоточен на идентичности с самим собой, а не с таким же.

На основании полученных данных [4,5,6] были получены снования для классификации признаков личностной идентичности по параметрам: внутренние -внешние, изменчивыеустойчивые (Таблица 1).

\begin{tabular}{|c|c|c|}
\hline & ВНУТРЕННИЕ & ВНЕШНИЕ \\
\hline ИЗМЕНЧИВЫЕ & направленность & поведенческие реакции \\
\hline УСТОЙЧИВЫЕ & характер & $\begin{array}{c}\text { индивидуальный } \\
\text { стиль деятельности }\end{array}$ \\
\hline
\end{tabular}

И теоретическое обоснование, и эмпирические данные показали содержание выделенных идентификационных категорий:

- направленность: чувства, желания, мечты, интересы личности.

- характер: отношение к миру, к людям, к себе, к труду. 
- индивидуальный стиль деятельности: привычки, стиль поведения, общения, манера разговора.

- поведенческие реакции: голос, мимика, взгляд, походка.

На основе полученных данных был проведен факторный анализ методом главных компонент с вращением по методу varimax. В результате было получено 3 фактора, объясняющих 66,9\% данных исследований экспериментальной группы (198 человек).

Таким образом, среди факторов личностной идентичности можно назвать внешний, внутренний и сквозной (временной фактор, который имеет отношение ко всем идентификационным признакам личности).

То есть, идентифицируясь с самим собой субъект использует внешние и внутренние признаки своей уникальности, тождественности, помещая эти параметры на временном векторе прошлое-настоящее-будущее.

\section{Литература:}

1. Заковоротная М.В. Идентичность человека. Социально-философские аспекты. Ростов-на Дону, Издательство Северо-Кавказского научного центра высшей школы. 1999.

2. Злоказов К.В. Современные модели развития идентичности личности (в контексте эриксонианской традиции) 1 // Педагогическое образование в России. 2015. № 11 с.99.

3. Кимберг А.Н. Субъект и идентичность. Личность и бытие: субъектный подход. Личность как субъект бытия: теоретико-методологические основания анализа: Матер. III Всерос. науч.-практ. конф. / Под ред. З.И. Рябикиной, В.В. Знакова. - Краснодар: Кубанский гос. ун-т, 2005. С. 97-108.

4. Макаревская Ю.Э. Личностная идентичность: диагностика и классификация признаков // Дружининские чтения: сборник материалов XII Всероссийской научнопрактической конференции, 23-25 мая 2013 г., г. Сочи, Сочинский государственный университет [Электронный ресурс] / под ред. И.Б. Шуванова, С.В. Воронина, Ю.Э. Макаревской, А.А. Смирновой. Электрон. текст. дан. (1 файл 2,8 Мб) - Вып. 2. - Киров: МЦНИП, 2013. - 417 с. - 1 электрон. опт. диск (CD-ROM). - ISBN 978-5-906223-23-4. с.165171 Номер государственной регистрации сборника: 0321303247

5. Макаревская Ю.Э. Содержательные компоненты личностной идентичности: межполовые различия. // Личностная идентичность: вызовы современности: материалы Bсерос. психол. науч.-практ. конф. (с иностранным участием) / под ред. З.И. Рябикиной и В.В. Знакова. - Майкоп: Адыгейский гос. ун-т; Краснодар: Кубанский гос. ун-т; М.: Институт психологии РАН, 2014. - 223.

6. Макаревская Ю.Э., Нерсесян Э.А. Символическое моделирование признаков личностной идентичности // Материалы съезда Российского психологического общества / сост. Л.В. Артищева; под ред. А.О. Прохорова, Л.М. Попова, Л.Ф. Баяновой и др. - Казань: Изд-во Казан. ун-та, 2017. - Т. 2. С. 409-411.

7. Психология личности в трудах отечественных психологов / Сост. Куликов Л.В. СПб: 2000. - 480c.

8. Рябикина 3.И. Личностная идентичность в ситуации изменения системы идентификаций (социо-психологические эффекты украинского разлома) // Известия саратовского университета. Нов. сер. Серия. Акмеология образования. Психология развития. 2014. Т3, вып. 3(11). С 263-266.

9. Рябикина 3.И. Личность. Личностное развитие. Профессиональный рост. Монография - Краснодар, 1995.

10. Слободчиков В.И. Развитие субъективной реальности в онтогенезе: Автореф. докт. дис. М., 1994.

11. Танасов Г.Г. Личность в переговорах: субъектно-бытийный подход / Автореферат диссертации на соискание ученой степени доктора психологических наук. - Краснодар. 2011. - 48 стр.

12. Хабермас Ю. Понятие индивидуальности // Вопросы философии. 1989. ⒉ 
13. Эриксон Э. Идентичность: юность и кризис: Пер. с англ. / Общ. ред. и предисл. Толстых А.В. - М.: Издательская группа «Прогресс», 1996. - 344c.

14. Baumeister R. Identity. Cultural Change and Struggle for Self. N.Y., Oxford, 1986.

15. Bazerman M.H., Loewenstein G.F., White S.B. Psychological determinants of utility in competitive contexts: The impact of elicitation procedures // Administr. Sci. Quart. 1992. V. 37. P. $220-240$.

Сериков Г.В.

\title{
К ВОПРОСУ О ВЛИЯНИИ ВНЕШНЕГО ОБЛИКА ЧЕЛОВЕКА НА ЕГО СТАТУС В ГРУППЕ*
}

\author{
*Исследование выполнено при поддержке Российского научного фонда, \\ проект № 171801260 «Социальная психология внешнего облика: функции, значимость, \\ удовлетворенность, обеспокоенность, интерпретации в межсличностном и \\ внутригрупповом взаимодействии в молодежной среде».
}

Актуальность исследований, направленных на изучение факторов влияющих на статус человека в группе не вызывает сомнений. Исследователи уже давно предположили, что борьба за статус в социальной группе (как отражающая уровень субъектности личности активность) носит универсальный характер, поскольку высокий статус дает человеку ряд преимуществ [9]. Проблема взаимосвязи внешнего облика и статуса человека в группе является достаточно сложной вследствие ряда понятийных и методологических трудностей.

Во-первых, само понятие «статус» охватывает различные его виды и требует каждый раз уточнения, о каком виде статуса идет речь: социальный статус, личный статус, предписанный, достигаемый, социометрический (который, в свою очередь подразделяется на коммуникативный, доверительный, референтный, идентификационный) и т.п. [7]. Кроме того, как пишет Я.Л. Коломинский [5] при изучении социометрического статуса в силу его неразрывного единства с поведением и качествами личности можно одновременно говорить и о влиянии каких-либо переменных на статус, и о формирующем воздействии статуса на эти переменные. Методологическая трудность при изучении личности и ее статуса состоит, по мнению автора, «в отсутствии общей непротиворечивой концепции личности, из которой необходимо исходить при анализе данных конкретного исследования» [там же, с 274]. Поскольку исследователи используют различные методы или авторские модификации методик при изучении мотивации социометрического выбора - это создает дополнительные трудности при сравнении и обобщении полученных в эмпирических исследованиях результатов. Социокультурные особенности также вносят свои проблемы при сравнении результатов. Наконец трудность эмпирического исследования взаимосвязи тех или иных качеств личности и ее статуса в группе обусловлена как слабой разработанностью проблемы качеств личности, критериев их выделения и перечня [1], так и большим количеством личностных характеристик его детерминирующих, поскольку: «процесс внутригруппового структурирования настолько сложен, что не может полностью определяться каким бы то ни было общим фактором» [8, с.65].

Во-вторых, понятие «внешний облик» также представляет собой сложный конструкт. В отечественной социальной психологии в рамках научной школы В.А. Лабунской внешний облик человека рассматривается как объективация внутреннего, сущностного в человеке. При этом, выступая в качестве интегрального, целостного образования, внешний облик складывается из отдельных в различной степени устойчивости-динамики компонентов [6]. Каждый из них в зависимости от социокультурно заданных стандартов, эталонов, стереотипов и т.п. вносит свой неравнозначный вклад в «общую картину», в различной степени «презентируя», делая доступным внутреннее личности. А.А. Бодалев, имея в виду 
эту, раскрывающую внутреннее одного человека другому человеку функцию различных элементов его физического облика, использовал понятие «признаки», подразделяя их на анатомические и функциональные. О последних он замечает: «Сложные психологические образования, которые представляют собой непрерывно перестраивающиеся по ходу деятельности ансамбли процессов и состояний, динамично выражаются во внешнем облике и поведении человека в виде совокупности определенных признаков, организующихся в пространственно-временные структуры взаимодействия людей друг с другом или с самим собой» [3, с. 117]. Согласно А.А. Бодалеву во внешний облик включается все, что доступно восприятию, не только «тип сложения, половые и расовые особенности», но и «мимика, жестикуляция, походка, осанка, голос, а также речь» [там же, с. 116-117], что предполагает неполноту его исследования лишь по статичным фотоизображениям.

В этой связи интерес представляют работы, выполненные в русле отечественной и зарубежной социальной психологии, в которых взаимосвязь статуса и внешнего облика исследовалась в группах, члены которых длительное время непосредственно взаимодействовали друг с другом, имея тем самым, возможность в полной мере оценить и внешний облик друг друга и личностные характеристики.

Задача данного сообщения - представить краткий обзор двух публикаций, посвященных влиянию внешнего облика на статус человека в группе, описать методы исследований и их результаты, сравнить подходы и теоретические установки.

В исследовании И.И.Дроздовой и В.А. Лабунской [4] авторы (со ссылкой на вышеуказанную работу Я.Л. Коломинского) рассматривали статус как интегральное понятие, которым охватывается не только объективное положение личности в структуре группы, но и ее субъективное, отрефлексированное в разной степени восприятие этого положения. Это крайне важная социально-психологическая характеристика человека, в которой отражается «положение субъекта в системе межличностных отношений, определяющее его права, обязанности, определенные привилегии в группе, а также уровень признания и принятия личности членами группы» [там же, с.1802],.

Задачей исследователей было определить то, как влияют оценки внешнего облика студента на его социально-психологический статус («эмоциональный» и «деловой») в группе (это были реальные студенческие группы, в которых участники (юноши и девушки) к моменту исследования знали друг друга уже более 2-х лет). Показатели статуса связывались с оценкой внешнего облика человека другими членами группы и с его самооценкой, что выявлялось с помощью методики «Оценочно-содержательная интерпретация компонентов внешнего облика» [6]. Внешний облик характеризовался с точки зрения его физической компоненты-показателя (лицо, телосложение), социальной (его оформление) и экспрессивной (выразительное поведение). Что касается социометрического статуса, то он определялся для каждого члена группы в соответствии с двумя классическими критериями: «эмоциональному» (совместное время препровождение) и деловому («связанному с учебой»).

В результате авторы пришли к выводу о прямо пропорциональной связи показателей этих двух видов статуса респондентов с групповыми оценками их внешнего облика. При этом на «эмоциональный статус» студентов влияют и групповые оценки внешнего облика (они оказались выше по всем трем компонентам-показателям у тех, у кого выше данный вида статуса) и их самооценки. Студенты с более высоким «эмоциональным статусом» значимо выше оценивали свой внешний облик, в особенности его физическую и экспрессивную компоненты. «Деловой статус» оказался связанным только с групповыми оценками внешнего облика. Эти оценки тем выше, чем выше такой статус. Что касается самооценки студентов с более выраженными показателями «делового статуса», то они выше оценивали свое телосложение, чем студенты с более низким «деловым статусом», но и групповые оценки их внешнего облика были выше (особенно их выразительного поведения), чем у студентов с низкими показателями этого вида статуса. По мнению авторов - это важный 
аспект полученных результатов, поскольку высокий «деловой статус» обычно не связывают с внешним обликом субъекта.

Таким образом, рассмотренное выше исследование включало в себя анализ влияния всех компонентов внешнего облика на статус студентов в ходе непосредственного взаимодействия в реальных группах, и в этом его эвристическая ценность. Кроме того, наличие установленной авторами связи более высоких показателей делового статуса с более высокими групповыми оценками внешнего облика показывает, что внутренние качества человека, его интеллект, его способности решать задачи - достаточно высоко ценятся в студенческом сообществе, вызывают уважение, что и вносит свои коррективы в групповые оценки его внешнего облика. Результаты исследования также наводят на мысль о том, что возможно, благодарность за сотрудничество и помощь человека с высоким деловым статусом также оказывает свое влияние на оценки его внешнего облика. Выявленная в данной работе более низкая по сравнению с самооценкой внешнего облика его групповая оценка может свидетельствовать о зависти к внешней привлекательности, о своего рода «перцептивной защите» как «попытки игнорировать при восприятии какие-то черты другого человека и тем самым как бы выстроить преграду его воздействию» [1, с. 311], об адлеровском «стремлении к превосходству», влиянии конкуренции, соперничества, отсылает к мысли М.М. Бахтина [2] об ограниченной, фрагментарной доступности внешнего «Я» человека, «внешнего тела» собственному восприятию и о роли другого человека в признании его ценности.

Многоэтапное исследование связи привлекательного внешнего облика, личностных характеристик и статуса в группе, выполненное зарубежными исследователями С. Anderson., O. John., D. Keltner, A. Kring [10] также проходило в реальных студенческих группах. В качестве показателей статуса в группе выступали уважение, влияние на ее членов, известность. Авторы рассматривали статус как функцию: стремления индивида и его способности к достижению статуса в ситуациях межличностного взаимодействия («in interpersonal settings») и конгруэнтности личностных черт с теми характеристиками, которые ценятся в группе. Высокий статус предполагает больше внимания к данному члену группы со стороны остальных ее членов, его известность, поскольку он у всех на виду, уважение, возможность осуществлять влияние и контроль и т.п. Объектом исследования выступили три больших группы, в каждой из которых было несколько десятков студентов в возрасте 19-20 лет: «студенческое братство» (чисто мужское объединение), «женский клуб» (соответственно чисто женская организация) и «университетское общежитие». Авторы предположили, что привлекательный внешний облик субъектов является предиктором получения ими более высокого статуса, поскольку предыдущие исследования других ученых показали, что: данная характеристика высоко ценится; в ходе социального взаимодействия, на этих людей смотрят больше, чем на некрасивых; у них более позитивное социальное взаимодействие (больше друзей, большее количество свиданий, больше возможностей зарабатывать); им приписывают те положительными характеристики, которыми они вовсе не обладают («гало-эффект). Предполагалось также, что в ходе длительного взаимодействия вышеуказанные социально-перцептивные искажения исчезают. Задачей исследования было попытаться отделить влияние личностных характеристик на статус человека в группе от влияния его привлекательного внешнего облика. Кроме того, C.Anderson и его коллеги ожидали, что будет обнаружена более сильная позитивная связь между привлекательным внешним обликом и статусом у женщин. Исследователи применили следующие методики: взаимное ранжирование (рейтинги) статуса, самооценки по пятифакторному опроснику «Большая пятерка» и ранжирование привлекательности внешнего облика. В отношении последнего показателя авторы констатируют, что существует так называемая «статичная привлекательность» (носящая физиогномический характер и определяемая на основе фотографии) и «динамическая привлекательность», которая и оценивалась в их исследовании на основе 10 секундной видеозаписи первичного инструктажа каждого участника. Исследование внешней привлекательности в «студенческом братстве» 
осуществлялись методом шкалирования от 1 («совсем не привлекательный человек»), до 7 («очень привлекательный»). Статус определялся таким же образом по шкале «известности»: от 1 («не знаю такого) до 4 («знаю очень хорошо»). Кроме того, у респондентов была возможность «назначить» оцениваемого человека на какую-либо престижную позицию в данном сообществе («председатель», «руководитель соревнования» и т.п.) Результаты показали, что фактор привлекательного внешнего облика в мужском сообществе был значимо связан с достижением более высокого статуса. При этом данный фактор не коррелировал ни с одним из факторов опросника «Большая пятерка». Следует отметить, что авторы не исключают возможность достижения более высокого статуса за счет личностных факторов, а не только за счет привлекательного внешнего облика. Просто они утверждают, что это два независимых «пути» к его достижению.

В женской выборке респондентов («женский клуб») респондентам необходимо было таким же образом, как и в мужской, оценить статус каждой девушки, плюс (по семибалльной шкале) степень влияния студентки (от «не обладает каким-либо влиянием на других» до «очень влиятельная»), а также ее известность по двухполярной шкале (от «не видна до «очень заметна»). Оказалось, что фактор привлекательного внешнего облика в женском сообществе не был значимо связан с достижением в нем более высокого статуса. В смешанной группе («общежитие») в лонгитюдном исследовании так же не было выявлено подобной связи. Иными словами в мужской по составу группе привлекательный внешний облик действительно помогал достижению более высокого статуса и популярности молодого человека из-за потенциальной возможности большего количества «романтических свиданий». Однако в «чисто женской» студенческой группе такой связи не было выявлено. Авторы предположили несколько объяснений: во-первых, мужчины ценят привлекательный внешний облик потенциального партнера в большей степени, чем женщины, то есть женщины могли не принимать этот фактор во внимание, а ориентироваться на другие характеристики; 2) привлекательный внешний облик девушки также как и у парня способствует росту ее популярности и большему количеству свиданий, но из-за существующих гендерных норм это не оказывает значимого влияния на ее статус (уважение, известность, влияние).

Выше приведенное исследование показало основные методические и методологические подходы к изучению взаимосвязи внешнего облика и статуса в группе за рубежом. Оно продемонстрировало как «точки пересечения», сходство теоретических установок и задач с отечественными исследователями (стремление изучать не «статические», но «динамические» признаки внешнего облика, ориентацию на реальные группы, в которых влияние различных факторов проявляется в ходе длительного взаимодействия и позволяет устранить социальноперцептивные искажения; стремление выявить «чистые связи» (свободные от влияния личностных характеристик) показателей внешнего облика и статуса человека в группе; констатацию роли и значимости статуса молодых людей в студенческий период их жизни и т.п.), так и различия (в формулировке и понимания статуса и его показателей, наличия таких социокультурных образований как: «женский клуб», мужское «студенческое братство», задающих специфику межличностного взаимодействия; акцент на гендерные нормы), что и задает в конечном итоге трудности сравнения, обобщения и интерпретации полученных результатов, трудности, о которых упоминалось в начале данной статьи.

\section{Литература}

1.Андреева Г.М. Социальная психология. М.: Аспект Пресс, 1997. - 376 с.

2. Бахтин М.М. Эстетика словесного творчества. М.: Искусство, 1986.

3.Бодалев А.А Личность и общение. М.: Международная педагогическая академия, 1995. $328 \mathrm{c}$.

4.Дроздова И.И., Лабунская В.А. Влияние оценок внешнего облика на «деловой» и «эмоциональный» статус студентов в группе. Фундаментальные и прикладные исследования современной психологии: результаты и перспективы развития. М.: «Институт психологии PAH», 2017. - 2704 c. 
5.Коломинский Я.Л. Социальная психология взаимоотношений в малых группах. М., ACT, 2010. - 446 c.

6.Лабунская В.А. Не язык тела, а язык души! Психология невербального выражения личности. Ростов-на-Дону, 2009. - 344 с.

7.Сидоренков А.В. Социальная психология малых групп, Ростов-н/Д., Феникс, 2011. $382 \mathrm{c}$.

8.Чернышова Е.А. Взаимосвязь особенностей систем личностных конструктов студентов и их статусной позиции в учебных группах // Социальная психология и общество. 2012. № 1 , c. 59-72.

9. Anderson C., John O., Keltner D., Kring A. Who Attains Social Status? Effects of Personality and Physical Attractiveness in Social Groups // Journal of Personality and Social Psychology, 2001, Vol. 81, No. I, pp.116-132.

Углава Я.М.

\section{ПСИХОЛОГИЧЕСКАЯ УСТОЙЧИВОСТЬ ЛИЧНОСТИ КАК БАЗОВАЯ ХАРАКТЕРИСТИКА АНТИКОРРУПЦИОННОГО ПОВЕДЕНИЯ ЛИЧНОСТИ}

В настоящее время, как в России, так и за рубежом, возрастает интерес к научным исследованиям, направленным на изучение психологических детерминант антикоррупционного поведения в целях совершенствования системы противодействия коррупционным проявлениям.

Коррупция является одной из главных проблем современной России, а эффективность борьбы с ней находится в прямой зависимости от антикоррупционной устойчивости личности. Важным условием успеха на пути формирования нравственного общества выступает знание особенностей антикоррупционной устойчивости личности, а значит, и борьбы с коррупцией.

Вопрос о психологических условиях и механизмах формирования психологической устойчивости личности к коррупционным проявлениям в ситуации коррупционного давления (антикоррупционной устойчивости) считается неразрешенным.

Такое положение во многом обусловлено наличием неразрешённых методологических проблем, в том числе и вопросов, связанных с системным рассмотрением личности в целом.

Таким образом, возрастает потребность в теоретическом осмыслении проблемы устойчивости и психологической устойчивости личности как научного феномена.

В современной науке понятие «устойчивость» до сих пор остается дискуссионным и имеет многочисленные варианты трактовки. Для того чтобы изучить данный термин более подробно, необходимо обратиться к его этимологии.

В семантическое пространство слова «устойчивость» входят такие понятия как стабильность, стойкость, надежность, непоколебимость, неподверженность влиянию, постоянство, твердость, прочность, сопротивляемость.

В словаре С.И. Ожегова понятие устойчивости трактуется как «неподверженность изменениям, постоянность характеристик» [8]. В «Словаре синонимов русского языка» дается два синонима этого слова: «стабильность, надежность» [11]. «Стабильность» (от лат. stabilis - устойчивый, постоянный) понимается как важнейшая характеристика постоянства и ассоциируется с неизменностью, порядком и равновесием. «Надежность» интерпретируется как способность системы сохранять требуемое качество функционирования в различных условиях ее осуществления. Анализ и дальнейшее сопоставление данных понятий показывают, что «устойчивость» выражается через способность ее подсистем сохранять свою целостность под воздействием дестабилизирующих внешних и внутренних факторов.

В психологии понятие «устойчивость (tolerance, stability)» рассматривается в таких еe проявлениях, как устойчивость личности, устойчивость поведения, психическая и психологическая устойчивость, эмоциональная и эмоционально-волевая устойчивость, 
морально-психологическая устойчивость, нравственная устойчивость личности, трансситуативная устойчивость поведения личности и др.

Для выявления сущности антикоррупционной устойчивости личности необходимо изучить феноменологию психологической устойчивости.

Интегративное представление о психологической устойчивости, характерное для современного этапа развития психологической науки, возникло на основе синтеза различных концептуальных подходов.

В отечественных исследованиях психологическая устойчивость представлена в работах Е.П. Крупника, А.Е. Личко, О.В. Митиной, В.Н. Мясищева, В.Ф. Петренко, И.Р. Пригожина, К.В. Сельченока, В.И. Слободчикова, В.С. Степина, Л.Л. Рохлина, В.Э. Чудновского и др.

Психологическая устойчивость рассматривается, прежде всего, как равновесное состояние системы, сохраняемое посредством противодействия, нарушающего это равновесие внешними и внутренними факторами (Л.И. Божович, Л.С. Выготский, А.Р. Лурия, А.Н. Леонтьев, Б.Ф. Ломов, С.Л. Рубинштейн и др.).

В трудах Л.И. Божович под устойчивостью индивида понималась личность с устойчивой внутренней позицией, обладающая определенным иммунитетом по отношению к внешним воздействиям (личностным установкам, взглядам и убеждениям), способная сохранять свои личностные позиции в чуждых ей условиях, преобразив тем самым саму себя и окружающие обстоятельства. Была показана роль содержательной стороны мотивации в формировании устойчивости личности, ее обусловленность спецификой доминирующего мотива: оказалось, что стремление любыми средствами добиться сиюминутного благополучия («ситуационный эгоизм») — психологическая почва для возникновения неустойчивости личности [2; с. 101-111].

А.Н. Леонтьев подчёркивал, что «структура личности представляет собой относительно устойчивую конфигурацию главных, внутри себя иерархизированных, мотивационных линий» [5,6], а любые формы активности субъекта пересекаются между собой и образуют так называемый «центр личности» (Я), который находится «не в индивиде, не за поверхностью его кожи, а в его бытии» [5, с. 80]. «Я» включено в общую систему взаимосвязей человека и среды. Следовательно, реальное поведение человека зависит не только от его индивидуально-личностных особенностей, но и от тех ситуаций, в которые он бывает вовлечен.

Интересен подход В.Э. Чудновского, согласно которому устойчивость личности рассматривается в нравственном аспекте [12]. Выделяя два способа поведения приспособление к ситуации и преобразование обстоятельств в той же ситуации - можно подчеркнуть, что в условиях необходимости осуществления нравственного выбора возникает потребность действовать на максимуме активности, сохраняя при этом свое личностное «Я» от совершения аморальною поступка (нарушение принятых норм и правил, отступление от собственных принципов, ценностей и т.д.).

Во фрейдистских и психоаналитических учениях рассматриваются защитные механизмы, обеспечивающие психологическую устойчивость человека посредством разрешения конфликта трех личностных инстанций: Ид, Эго и Суперэго. При этом конфликтное взаимодействие между биологическими влечениями «Ид» с «цензорскими» нормативами «Суперэго» фиксируется в качестве постоянного внутриличностного противоборства. (А. Адлер, 3. Фрейд, Э. Фромм, К.Г. Юнг и др.).

При изучении психологической устойчивости особый интерес представляют собой те теоретические концепции, которые исследуют психические явления, происходящие на подсознательном уровне, то есть не осознаваемые субъектом. Так, идеи П. Жане о бессознательном как явлении, связанном с ослаблением сознательного влияния на поведение и психической диссоциацией, на наш взгляд, имеют большое значение для понимания самого феномена психологической устойчивости.

В исследованиях психологической безопасности психологическая устойчивость представляет собой характеристику личности, проявляющуюся во взаимодействии между 
отдельными людьми или группой лиц (О.В. Митина, К.В. Сельченок, В.И. Слободчиков и др.) Психологическая устойчивость в трудных жизненных ситуащиях - это целостная характеристика личности, которая способствует обеспечению устойчивости человека в фрустрирующем и стрессогенном мире, защищая от воздействия среды [10].

Изучая данный феномен в свете различных теорий и подходов, следует отметить, что психологическая устойчивость не может быть всеобъемлющей характеристикой личности, т.е. человек не способен быть «устойчивым» ко всем жизненным проявлениям. В рамках изучаемой нами тематики интересна точка зрения И.Н. Грызловой и И.А. Переверзева, которые считают, что психологическая устойчивость - это не устойчивость вообще, а устойчивость к изменениям конкретных параметров внешней среды. При этом, в зависимости от особенностей человека (внутренний фактор), конкретный аспект устойчивости каждого отдельного индивида может быть либо ниже, либо выше. Поэтому исследования психологической устойчивости личности должны учитывать характеристики как внешних (объективные конкретные ситуации), так и внутренних (потенциальные возможности человека) факторов.

Анализируя различные теории и подходы в изучении проблемы психологической устойчивости личности, отметим, что большинство исследователей определяют ее в качестве активного целостного психического образования, представляющего собой реакцию (либо отражение) личности на ситуацию, рассматриваемую как комплекс внешних и внутренних условий жизнедеятельности человека.

На основе вышеизложенного можно заключить, что устойчивость личности - это сложное системное образование, в интегральном описании которого можно выделить три составляющих, позволяющих удерживать эмоциональные, когнитивные, конативные процессы и процессы деятельности в равновесном состоянии, адаптировано реагировать на внешние воздействия в ситуациях фрустрирующего и стрессогенного воздействия, обеспечивая психологическую безопасность личности, а также способствовать разрешению внутриличностных конфликтов:

- стойкость, стабильность - способность противостоять трудностям, сохранять веру в себя и свои возможности;

- уравновешенность - соразмерность силы реагирования, активности поведения силе раздражителя, значению событий (величине положительных и отрицательных последствий, к которым они могут привести);

- сопротивляемость - способность противостоять всему, что может ограничить свободу личности в принятии отдельных решений и в выборе ценностей, норм, жизненных позиций, образа жизни в целом [9].

Способность противостоять негативным влияниям социальной среды развивается в процессе жизнедеятельности и теснейшим образом связана с отражением собственных возможностей человека, опытом разрешения аналогичных ситуаций, выбором способа преодоления препятствий.

Психологические исследования показывают, что формирование устойчивости как сложной системной характеристики личности в онтогенезе проходит ряд этапов: стрессоустойчивость (формируется в детском возрасте), психологическая устойчивость (в подростковом возрасте); психологическая безопасность (в юношеском возрасте); психологическая культура (формируется в молодости и далее - взрослом возрасте) [1].

Особую значимость в формировании устойчивости личности к негативным влияниям социальной среды, в том числе и преступлениям коррупционной направленности, имеет подростковый период, период ранней юности и молодости, который И. С. Кон назвал «третьим миром», существующим между детством и взрослостью [4; с. 66].

Обобщая существующие взгляды на проблему психологической устойчивости, уже сейчас можно отметить, что еe характерные признаки образуют особую организацию существования личности как системы, обеспечивающей максимально эффективное ее функционирование. 
В целом устойчивость как внутренне противоречивая система является не только возможностью личности противостоять коррупционному поведению, негативным аспектам социальных изменений, но и главной основой внутриличностного развития человека.

А наиболее общим критерием устойчивости в исследованиях различных авторов выступает субъективный жизненный мир, который выстраивается человеком в процессе его жизненного пути по определенной жизненной стратегии [3; с. 60].

Отталкиваясь от разработанных представлений об устойчивости, психологической устойчивости, можно определить антикоррупционную устойчивость личности как системное свойство личности, проявляющееся в способности противостоять коррупционному давлению и осуществлять выбор между криминальным и законопослушным поведением в пользу последнего [7, с. 147].

Антикоррупиионная устойчивость, по нашему мнению, включает в себя две основные подструктуры.

Первая подструктура - это морально-психологическая устойчивость, т.е. подчинение личного поведения в повседневной жизни и профессиональной деятельности моральным нормам при действии факторов, подталкивающих к отступлению от них (коррупционное давление).

Вторая подструктура - собственно психологическая устойчивость как способность противостоять психологическим трудностям, возникающим в процессе профессиональной деятельности, определяющаяся степенью сформированности структуры личности, обеспечивающей необходимый уровень самодетерминации поведения.

На основании вышеизложенного можно заключить, что личность, имеющая высокий уровень психологической и морально-психологической устойчивости, характеризуется преобладанием устойчивых индивидуальных установок (моральных, социальных и правовых), ответственностью за события своей жизни, а также способностью противостоять коррупционному поведению, осуществляя выбор в пользу законопослушного (личность с высоким уровнем антикоррупционной устойчивости).

Выявление и повышение уровня психологической и морально-психологической устойчивости личности к коррупционному поведению будет способствовать качественному выполнению служебной деятельности без отступления от предписанных правовых норм, психологической подготовке к действиям в сложных ситуациях, а также нравственноправовому становлению личности.

\section{Литература}

1. Андреев И.В. Формирование психологической устойчивости студентов к негативному влиянию Интернет-технологий: Автореф. дисс ....канд. психол. наук. Нижний Новгород, 2008.

2. Божович Л. И. Устойчивость личности, процесс и условия ее формирования // Материалы XVIII Международного психологического конгресса. Симпозиум 35: Формирование личности в коллективе. - М., 1966. - 101-111с.

3. Василенко, Е.В. Профессионально-психологическая устойчивость сотрудников ОВД // Вестник СГУ - Выпуск 52. - Ставрополь: Изд-во СГУ. - 2007.

4. Кон И.С. Психология юношеского возраста. М., 1989. - 66 с.

5. Леонтьев А.Н. Деятельность. Сознание. Личность. - М.: Политиздат, 1977. - 304 с.

6. Леонтьев А.Н. Проблемы развития психики / А. Н. Леонтьев. - М.: Изд-во МГУ, 1981. $-584 \mathrm{c}$.

7. Никонова Э.И., Абдрахманова Л.В. Коррупция и борьба с ней: теория и практика. Учебное пособие для студентов всех форм обучения / сост. Э.И.Никонова, Л.В. Абдрахманова, - Казань: Изд-во ООО «16 ПРИНТ», 2016. - 194 с. 
8. Ожегов С.И. Словарь русского языка / Под ред. Н.Ю. Шведовой. - 20-е изд., стереотип. - М.: Русский язык, 1988.

9. Платонов К.К. Структура и развитие личности. - М.: Наука. 1986. - 255 с.

10. Психология экстремальных ситуаций / Т. Н. Гуренкова, И. Н. Елисеева, Т. Ю. Кузнецова О. Л. Макарова, Т. Ю. Матафонова, М. В. Павлова, Ю. С. Шойгу. М., 1997.

11. Словарь синонимов русского языка / Под ред. А.П. Евгеньевой. - Л., 1970.

12. Чудновский В.Э. Воспитание способностей и формирование личности. - М.: Знание, 1986. 


\section{Сведения об авторах}

\begin{tabular}{|c|c|c|c|c|c|}
\hline $\begin{array}{l}\text { № } \\
\text { п/ா/ா }\end{array}$ & Ф.И.О. & Статус & Город & Организация & e-mail \\
\hline 1 & Андриенко Т.А. & магистр & $\begin{array}{l}\text { Ростов-на- } \\
\text { Дону }\end{array}$ & ЮФУ & $\begin{array}{l}\text { tatiana.andrienko2015@yan } \\
\text { dex.ru }\end{array}$ \\
\hline 2 & Базалева Л. А. & к.пс.н. & Сочи & СГУ & lbazaleva@mail.ru \\
\hline 3 & Базалев С.А. & & Сочи & & sbazalev16@gmail.com \\
\hline 4 & Гижицкий В.В. & к.пех.н. & Москва & $\begin{array}{c}\text { Первый МГМУ им. } \\
\text { И.М. Сеченова }\end{array}$ & viktor.gizhitsky@yandex.ru \\
\hline 5 & Горская Г.Б. & $\begin{array}{l}\text { Д.псх.н., } \\
\text { профессор }\end{array}$ & Краснодар & КГУФКСТ & gorskayagalina@mail.ru \\
\hline 6 & Гусейнов А.Ш. & $\begin{array}{l}\text { д.пс.н., } \\
\text { доцент }\end{array}$ & Краснодар & КГУФКСТ & AGuseinov@yandex.ru \\
\hline 7 & Деева Н.А. & $\begin{array}{l}\text { к.псх.н., } \\
\text { доцент }\end{array}$ & Краснодар & КрУ МВД России & natalya_deeva@bk.ru \\
\hline 8 & Дёмин А.Н. & д.псХ.н & Краснодар & КубГУ & demin@manag.kubsu.ru \\
\hline 9 & Дубовицкая Т.Д. & $\begin{array}{l}\text { д.псх.н., } \\
\text { проф }\end{array}$ & Сочи & СГУ & tatdm@mail.ru \\
\hline 10 & Егорова В.С. & $\begin{array}{c}\text { к.псх.н., } \\
\text { доцент } \\
\text { академии } \\
\text { искусств }\end{array}$ & $\begin{array}{c}\text { Штип, } \\
\text { Македония }\end{array}$ & $\begin{array}{c}\text { Университет Гоце } \\
\text { Делчев }\end{array}$ & chikarina1@rambler.ru \\
\hline 11 & Ермолова В. О. & acп. & Сочи & СГУ & e.v.o.gray@mail.ru \\
\hline 12 & Зинатуллина А.П. & $\begin{array}{c}\text { магистр } \\
\text { психологии }\end{array}$ & Сочи & $\begin{array}{c}\text { Управление } \\
\text { вневедомственной } \\
\text { охраны по г.Сочи- } \\
\text { филиал ФГКУ "УВО } \\
\text { ВНГ России по } \\
\text { Краснодарскому } \\
\text { краю" }\end{array}$ & $\begin{array}{l}\text { zinatullina.anastasiya@mail } \\
\text {.ru }\end{array}$ \\
\hline 13 & Кара Ж.Ю. & $\begin{array}{l}\text { к.псх.н, } \\
\text { доцент }\end{array}$ & $\begin{array}{l}\text { Ростов-на- } \\
\text { Дону }\end{array}$ & АПП ЮФУ & kara_j@mail.ru \\
\hline 14 & Киреева О.В. & $\begin{array}{l}\text { к.псх.н, } \\
\text { доцент }\end{array}$ & Краснодар, & КубГУ & oksana-kireeva@mail.ru \\
\hline 15 & Князева Г.Н. & $\begin{array}{l}\text { к.п.Н., } \\
\text { доцент }\end{array}$ & Краснодар & КубГУ & elena-knyazeva@yandex.ru \\
\hline 16 & Князькова М.Г. & $\begin{array}{c}\text { к.ю.н., } \\
\text { магистр } \\
\text { психологии }\end{array}$ & Сочи & СГУ» & margoshaum@mail.ru \\
\hline 17 & Кругликова А.Ю. & $\begin{array}{c}\text { к.псх.н., } \\
\text { доцент }\end{array}$ & Таганрог & $\begin{array}{l}\text { ЦПК ФГБОУ ВО } \\
\text { «РГЭУ(РИНХ)» }\end{array}$ & annkru@mail.ru \\
\hline 18 & Крутелева Л.Ю. & $\begin{array}{c}\text { к.псх.н., } \\
\text { доцент }\end{array}$ & $\begin{array}{l}\text { Ростов-на- } \\
\text { Дону }\end{array}$ & АПП ЮФУ & kruteleva@sfedu.ru \\
\hline 19 & Курцов Н.А & $\begin{array}{l}\text { педагог- } \\
\text { психолог }\end{array}$ & Сочи & $\begin{array}{l}\text { МДОБУ Детский сад } \\
\text { №93 }\end{array}$ & $\begin{array}{l}\text { mastermind2710@yandex.r } \\
\text { u }\end{array}$ \\
\hline 20 & Лабунская В.А. & $\begin{array}{l}\text { д.псх.н., } \\
\text { профессор }\end{array}$ & $\begin{array}{l}\text { Ростов-на- } \\
\text { Дону }\end{array}$ & ЮФУ & vlab@aaanet.ru \\
\hline 21 & Левченко Е.В & $\begin{array}{l}\text { магистр } \\
\text { психологии }\end{array}$ & $\begin{array}{c}\text { Новосибирс } \\
\text { к }\end{array}$ & $\begin{array}{c}\text { Православный } \\
\text { Приход во имя св. } \\
\text { апостола Андрея } \\
\text { Первозванного } \\
\end{array}$ & pevl@narod.ru \\
\hline 22 & Меньшикова Л. В. & $\begin{array}{c}\text { Д.Псх.Н., } \\
\text { профессор }\end{array}$ & $\begin{array}{c}\text { Новосибирс } \\
\kappa\end{array}$ & НГТУ & melavl@mail.ru \\
\hline 23 & Макаревская Ю.Э. & $\begin{array}{l}\text { к.пс.н., } \\
\text { доцент }\end{array}$ & Сочи & СГУ & yuliya-sochi@mail.ru \\
\hline 24 & Макаревская И.Г. & ст.преп & Сочи & СГУ & athoc@yandex.ru \\
\hline 25 & Негрий В.А. & мл.н.сотр & Москва & МГУ им. Ломоносова & v.negrii@gmail.com \\
\hline 26 & Окорокова А.В. & магистрант & Сочи & СГУ & anka0191@mail.ru \\
\hline
\end{tabular}




\begin{tabular}{|c|c|c|c|c|c|}
\hline 27 & Пшеничный Д.К. & бакалавр & Сочи & СГУ & - \\
\hline 28 & Петросьян С. Н. & $\begin{array}{l}\text { к.Пс.н., } \\
\text { доцент }\end{array}$ & Сочи & СГУ & svpet@mail.ru \\
\hline 29 & Педанова Е.Ю. & к.Псх.Н., доц & Краснодар & КубГу & spsy@manag.kubsu.ru \\
\hline 30 & Рябикина З.И. & $\begin{array}{c}\text { д.псх.н., } \\
\text { проф }\end{array}$ & Краснодар & КубГу & z.ryabikina@yandex.ru \\
\hline 31 & Самохвалова А.Г. & & Кострома & $\begin{array}{c}\text { КГУ им. } \\
\text { Н.А.Некрасова }\end{array}$ & a_samohvalova@ksu.edu.ru \\
\hline 32 & Серегин А.В. & $\begin{array}{l}\text { учитель } \\
\text { истории } \\
\end{array}$ & Сочи & МОБУ СОШ №11 & - \\
\hline 33 & Сериков Г.В. & & $\begin{array}{c}\text { Ростов-на- } \\
\text { Дону }\end{array}$ & ЮФУ & serikovg@mail.ru \\
\hline 34 & Сухих С.А. & $\begin{array}{c}\text { д.филол.н } \\
\text { проф. }\end{array}$ & Краснодар & КубГу & Suhih_52@mail.ru \\
\hline 35 & Теплякова А.П. & студент & Сочи & СГУ & anastepl@mail.ru \\
\hline 36 & Тучина О. Р. & $\begin{array}{l}\text { д.пс.х.н, } \\
\text { доцент }\end{array}$ & Краснодар & КубГТУ & tuchena@yandex.ru \\
\hline 37 & Углава Я.М. & acп. & Сочи & СГУ & jana2929@mail.ru \\
\hline 38 & Фролов А.А. & ст.преп & Краснодар & КрУ МВД России & ajeduk@mail.ru \\
\hline 39 & Шеханина К.В. & аспирант & Сочи & СГУ & k.shekhanina@gmail.com \\
\hline 40 & Шиповская В.В. & $\begin{array}{l}\text { к.пс.н., } \\
\text { доцент }\end{array}$ & Краснодар & МАОУ ВО ММИВСО & victship@mail.ru \\
\hline 41 & Шкурко Т.А. & $\begin{array}{c}\text { к.псх.н., } \\
\text { доцент }\end{array}$ & $\begin{array}{c}\text { Ростов-на- } \\
\text { Дону }\end{array}$ & ЮФУ & shkurko@sfedu.ru \\
\hline 42 & Чепелева Л.М & к.псх.Н. & Краснодар & КубГу & - \\
\hline
\end{tabular}




\title{
Научное издание
}

\section{Психология безопасности и психологическая безопасность: проблемы взаимодействия теоретиков и практиков}

\author{
Сборник материалов \\ VIII Всероссийского научного семинара \\ г. Сочи, 28-29 сентября 2018 г.
}

В авторской редакичии

Технический редактор: Ю.Э. Макаревская

А.В. Окорокова

Компьютерная верстка: И.Г. Макаревская

Подписано в печать 10.11.2018.

Электрон. текст. дан. (1 файл)

Усл. печ. л. 6,3

Редакционно-издательский центр ФГБОУ ВО «СГУ». 354003, г. Сочи, ул. Пластунская, 94.

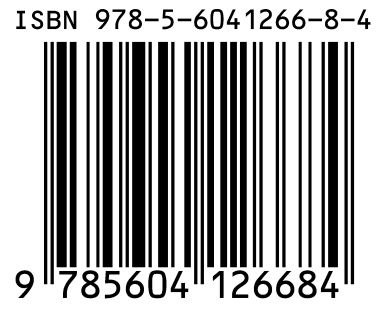

